\title{
IN SPECULO MENTIS PALAVRA E PENSAMENTO EM AGOSTINHO
}

\author{
Ricardo Reali Taurisano \\ Centro de Estudos Patrísticos e Medievais
}

\begin{abstract}
RESUMO: O objetivo principal deste artigo é investigar se a relação que Agostinho estabelece entre linguagem e pensamento, ou melhor, entre uma palavra proferida pela boca, ministra da fala, e uma palavra silenciosa revolvida na mente, ministra do pensamento, é uma relação de radical dissociação, como se tem interpretado, ou se a estrutura mínima que se percebe no modelo linguístico encontra-se igualmente no modelo cognitivo. Para tanto empreenderam-se análises de passagens escolhidas de escritos do autor nos quais essas duas noções de "palavra" se fazem objeto significativo de inquirição.
\end{abstract}

Palavras-chave: Agostinho, linguagem, pensamento, palavra.

\begin{abstract}
The main purpose of this article is to investigate whether the relationship Augustine stablishes between language and thought, or rather between a word uttered by the mouth, minister of speech, and a silent word stirred in the mind, minister of thought, is a relationship of radical dissociation, as it has been interpreted to be, or if the minimal structure that is perceived in the linguistic model is also present in the cognitive one. For this purpose were undertaken analyses of selected passages from writings of the author in which these two notions of "word" become a significant object of inquiry.
\end{abstract}

Keywords: Augustine, language, though, speech. 
Porque a palavra [ainda] não está em minha língua e tu, Senhor, a todas elas conheces, as últimas e as primeiras

S1 $138,4^{1}$

O pensamento realiza incontáveis operações para que falemos; no entanto, pelo fato de não serem conscientes, diagnosticou Benveniste (1966, pp. 63-64), difundiu-se por muito tempo a ideia de que pensar e falar eram duas atividades distintas. Todavia, nenhuma dissociação há entre pensamento e linguagem, asseverou o linguista francês, porque o conteúdo interior só adquire forma "da língua e na língua", que lhe constitui "o molde de toda expressão possível" (ibid.). Dessa impossibilidade de dissociação decorreria naturalmente a de transcendência, uma vez que não é senão à estrutura da língua, com seus signos decomponíveis em unidades menores e reagrupáveis em unidades mais complexas, que cabe imprimir forma ao pensamento. Assim o conteúdo mental deveria ser distribuído em morfemas de classes determinadas, numa certa ordem, se quisesse ser transmitido. Do contrário o pensamento se reduziria a nada, quando não, a algo tão vago e indiferenciado, apontou o linguista, que não seria possível apreendê-lo como algum conteúdo distinto da forma que a língua lhe confere. Daí ter sustentado peremptoriamente que a estrutura linguística não apenas constitui a condição sine qua non de sua transmissibilidade, mas também de sua própria realização, pois, não fosse "apropriado" pelas molduras da língua, nada mais seria que "volição obscura, impulso que se descarrega em gestos e mímica" (id. ibid.).

Se o pensamento se tem por irrealizável fora da linguagem, uma vez que, como disse Wittgenstein em um de seus apotegmas, não se pode cortar o galho sobre o qual se está sentado², parece decorrer necessariamente disso que o mundo não pode ser conhecido em si mesmo, constituindo-se apenas na linguagem, e por meio dela. Daí a pertinência de uma das questões mais discutidas no século XX, que tem despertado interesse multidisciplinar, se o que é representado pela linguagem é algum objeto que lhe é externo e independente, ou se, ao contrário, constitui-se e constrói-se por meio dela. A essa questão que se coloca, se as coisas podem ser conhecidas em si mesmas a despeito dos sujeitos que as pensam e falam, dá-se hoje resposta praticamente unânime: sem a linguagem o mundo restaria ininteligível. Logo, se nem o mundo

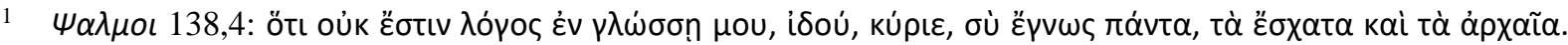
In: RAHLFS, Alfred. Septuaginta: Id est Vetus Testamentum Graece iuxta LXX interpretes. Stuttgart: Deutsche Bibelgesellschaft, 2004.

2 Investigações filosóficas (I.F.) §55:Ich darf mir nicht den Ast absägen, auf welchen ich setze.
} 
é conhecido sem a linguagem, nem o pensamento se realiza sem ela, diante da perplexidade causada pela diversidade e pluralidade das línguas, seria preciso reconhecer haver tantos mundos quantas línguas, caindo Babel por terra, ainda uma vez, e com ela o mito da língua universal e original de que se teriam derivado as demais. Todavia, como aponta Ricoeur (2011, p. 34), é precisamente em virtude da multiplicidade de línguas que a tradução sempre existiu. Com efeito, pondera o hermeneuta francês (ibid. p. 35), sempre houve intérpretes, mercadores, embaixadores, quer dizer, bilíngues e poliglotas. Demais, os homens falam, fazendo uso de signos, que apontam para si mesmos e para coisas outras que não eles, o que justificaria, segundo alguns, uma possível universalidade dos conteúdos. E de fato, quando alguém fala numa língua qualquer, como é possível que o que diga seja compreendido e traduzido em outra? Haveria assim algo anterior à linguagem, espécie de estrutura universal subjacente?

Herança da metafísica cartesiana, assevera Inês Araújo (2004, pp. 16-17), a ideia de que o sujeito é o artífice de suas próprias representações teria relegado a linguagem a uma função exclusivamente "referencial", espécie de instrumento "neutro" de representação, simples expressão do pensamento, ao invés de admiti-la como coautora do mundo. Isso de modo particular depois da chamada "virada linguística" (The Linguistic Turn) ${ }^{3}$, que fez surgir, em lugar do sujeito que pensa através das representações que retém em si, o sujeito que fala, "constituído nas e pelas trocas linguísticas às quais tem acesso, não pela introspecção, mas publicamente" (id. ibid. p. 19). À parte as teorias de Noam Chomsky ${ }^{4}$, a linguística e a filosofia da linguagem têm rejeitado a ideia de que a linguagem seja apenas uma roupagem do pensamento. Segundo a hipótese relativista de Edward Sapir e Benjamin Lee Whorf, por exemplo, cada língua, visto possuir sua sintaxe específica, não apenas não se apoia em qualquer base universal subjacente e preexistente, mas ainda constrói o universo mental de seus próprios falantes ${ }^{5}$. Do que decorre a ideia, hoje bastante enraizada, de que o próprio conhecimento do mundo depende intrinsecamente da linguagem, visto acreditar-se que ele seja "conceitualmente" ordenado pelas significações que o falante lhe atribui. Numa palavra, o homem vê o mundo através dos olhos da linguagem, fora da qual lhe é vedado o próprio pensar, pois ele só pensa porque aprendeu a

\footnotetext{
${ }^{3}$ Há quem prognostique, hiperbolicamente, como Stiver (2004), que o século XX será conhecido pela posteridade como o século da "virada linguística", a partir da expressão consagrada por Richard Rorty.

${ }^{4}$ Para Chomsky os conceitos têm independência em relação às línguas, visto considerá-los partes integrantes da gramática interna da mente humana, de sua estrutura inata.

${ }^{5}$ A diversidade das línguas humanas constitui empecilho insuperável ao conceito de Gramática Universal (GU), diz Auroux (2013, pp. 50-52), conceito esse que supõe que as línguas partilhem algo em comum que faz com que sejam línguas humanas, permitindo sejam traduzidas.
} 
falar, e apenas depois de tê-lo feito, uma vez que a linguagem não é somente o veículo do pensamento, como diz Wittgenstein ${ }^{6}$, mas também, em certo sentido, aquilo de que se constitui.

Vê-se que essas questões, que se encontram interconectadas: (1) a da relação entre a linguagem e o mundo, ou de como a linguagem o significa; (2) a da relação entre a linguagem e o pensar, ou da natureza do pensamento; (3) e a da universalidade dos conteúdos, ou da possibilidade de existência de uma estrutura anterior e preexistente à linguagem, interessam não apenas à filosofia da linguagem, mas também à do pensamento. É possível dizer ainda que elas têm, ainda hoje, como um de seus principais antimodelos, a despeito do prisma a partir do qual se pretenda considerá-las, o mesmo Agostinho, ou quiçá a interpretação que se tenha feito de seus escritos acerca da linguagem e do próprio pensamento; especialmente, mas de modo nenhum exclusivamente, de três de suas obras: o tratado juvenil inacabado, de ascendência supostamente estoica $^{7}$ e por muito tempo considerado espúrio, De dialectica (387); o diálogo De magistro (389); e uma de suas obras-primas da maturidade, De trinitate (399-422/6) ${ }^{8}$. Diz-se "antimodelo" porque, não apenas mas especialmente a partir de Wittgenstein, considera-se que Agostinho possuísse uma visão limitada e ingênua da linguagem, restrita à referência, uma vez o que lhe importava, segundo os críticos mais severos, eram o pensamento e as coisas, não a própria linguagem 9 . A partir de outro ângulo, o da filosofia chamada "do conteúdo", que se situa entre os dois polos, linguagem e pensamento, dir-se-ia que Agostinho era um representacionista avant la lettre, ao procurar explicar o significado linguístico como resultado do conteúdo mental. Isso porque para o representacionismo, explica Thornton (2007, p. 27), há uma "simetria" entre o pensamento e a linguagem, o que explicaria a "sistematicidade" que se supõe haver nas

\footnotetext{
${ }^{6}$ I.F. §329: die Sprache selbst ist das Vehikel des Denkens.

${ }^{7}$ Long $(2008$, p. 37) vê conexões mais certas com o De grammatica de Varrão.

${ }^{8}$ Acrescentem-se a esta lista algumas passagens significativas, que serão na sequência analisadas, dos seguintes escritos: Sermo 288 (401); De doctrina christiana (396-426/7); In Iohannis euangelium tractatus CXXIV (406419/20); Confessiones (397-401).

${ }^{9}$ Em I.F. (§1; §32) Wittgenstein critica aquilo que imagina ser a concepção agostiniana acerca da linguagem, e que era também a sua própria no Tractatus, como bem aponta Stiver (2004, p. 59). Trata-se de uma concepção que destacava palavras de seu contexto e lhes apontava referentes, do que o autor das I.F. veio depois a discordar, defendendo então a tese de que a filosofia devia ocupar-se com a descrição dos usos da linguagem, não com sua prescrição. Para o filósofo austríaco as palavras só têm sentido se consideradas em seus respectivos "jogos de linguagem" (Sprachspiele), que, contudo, são inumeráveis; daí ser preciso abdicar de considerá-la, a linguagem, pelo prisma da idealização, e voltar-se para seu uso cotidiano. Portanto, ao contrário da visão denominada tradicional, que priorizava o pensamento como algo anterior e absoluto, o filósofo austríaco defende que a linguagem é pública, e que as palavras só se definem por seu uso, numa "forma de vida" (Lebensform) que é um evento externo, já que nenhuma língua seria "privada". Muita controvérsia gerou a crítica de Wittgenstein acerca da aquisição da linguagem nas Confissões $(1,6,8 ; 8,13)$, que ele considerou "primitiva", um "retrato pré-filosófico acerca da linguagem", que teria originado todas as más teorias acerca dela, e que deveriam ser veementemente combatidas. Cf. Burnyeat (1987).
} 
representações mentais internas, sistematicidade essa que daria conta de justificar a própria estrutura composicional das sentenças ${ }^{10}$.

$\mathrm{O}$ que se pretende investigar aqui, nada obstante a densidade e complexidade do tema ultrapassarem em muito as limitações que se impõem para um texto dessa natureza, de par com os conhecimentos insuficientes de seu próprio autor, é se de fato a relação que Agostinho traça entre uma palavra silenciosa que se produz no coração e as palavras sonoras sopradas pela boca sustenta inequivocamente uma distinção radical e irremediável entre linguagem e pensamento, como se lhe tem imputado. Em suma, quer-se compreender como se relacionam palavra e pensamento, se a estrutura mínima que se percebe no modelo linguístico da primeira encontra-se igualmente no segundo, o que permitirá depreender sua relação, não apenas com o mundo criado captável pelos sentidos, mas também com o mundo suprassensorial, que seria também supralinguístico e suprarracional. Com efeito, se pensamento e discurso se equivalem, e se os discursos são constituídos de pequenas unidades, os nomes e os verbos, o discurso mental deveria igualmente ser constituído dessas mesmas unidades. Por outra, se se conclua que pensamento e palavra eram naturezas absolutamente distintas para ele, interessa compreender não apenas como seria o pensar acerca das coisas humanas, mas também como ocorreria a passagem de um a outro, da palavra inteligível à palavra sensível. Todavia, para além das preocupações atuais das filosofias da linguagem e da mente, é preciso atentar para o fato de que para Agostinho havia ainda outro gênero de pensar, que costuma ser desconsiderado quando se frequentam suas obras, um pensar ultrassilencioso acerca do impensável, pensar que, embora se dê também na mente humana, contudo se realiza asceticamente através da apófase, na negação de quaisquer movimentos do espírito, como antecipação da contemplação da Face divina, onde se espera alcançar a presença de uma atividade "inteligente" de outra natureza, não propriamente cognitiva, certamente nada volátil, que se vivencia no repouso da eternidade onisciente do Ser absoluto, onde se pensa o todo num agora sem fim.

Por outra, se o mundo é significado pela linguagem, como propugna por dizer a ótica relativista estribada sobremodo na etnolinguística de Sapir e Whorf, não pode ter sido o uerbum de Deus a tê-lo criado, e sim as palavras humanas, que o reedificam incessantemente, visto tratar-se de uma obra em pleno processo, logo inacabada; depois, se pensamento e linguagem são de fato uma só e mesma coisa, que seria o uerbum aeternum, Palavra-pensamento não

\footnotetext{
${ }^{10} \mathrm{O}$ representacionismo pretende explicar primeiro o conteúdo mental para, a partir daí, compreender o significado linguístico, derivando este daquele, porém de modo reducionista, quer dizer, naturalista, como se o conteúdo fosse derivado de causas naturais ou não intencionais. Esta posição, diz Thornton (2007, p. 35), é a ortodoxia atual na filosofia do conteúdo.
} 
circunscrita às cadeias contingentes da dimensão espaço-tempo, pela qual teria Deus, segundo o relato do Gênesis, criado o mundo, e com ele o próprio tempo, no qual, depois de feito carne, deu-se a conhecer aos homens? Por fim, se nenhuma estrutura anterior à linguagem dá sustentabilidade à qualquer conteúdo, nenhuma Verdade, tampouco Sabedoria ou Amor seriam possíveis em si mesmos, quer como substâncias, quer como conteúdos inatos da mente humana. Porém, se essas questões nenhuma importância têm para os que hoje se debruçam sobre a linguagem e o pensamento, eram não apenas prementes para Agostinho, mas acima de tudo assentavam os pressupostos sobre os quais todo o arcabouço de seu pensamento erigia-se, pressupostos que, caso desconsiderados, qualquer leitura que se intentasse de sua obra resvalaria na deformação, tão mais lamentável quanto mais desprezados fossem.

\section{Diálogos platônicos: entre dois lógoi}

Duas sendo as "palavras" cuja relação se quer investigar, pensamento e linguagem, interessa saber como surge e se desenvolve essa dicotomia, que Panaccio (2017, p. 69) assevera ter sido herdada por Agostinho da patrística grega ${ }^{11}$. O contraste estabelecido pelos antigos, em verdade, assentava-se sobre as noções de interioridade e exterioridade, entre uma palavra que

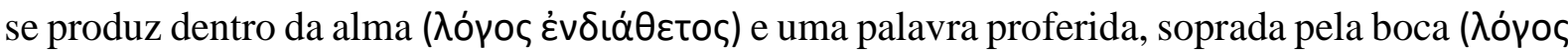
профорєко́ৎ), о que se percebe já em autores do primeiro século, como Plutarco, Cornutus e Fílon de Alexandria, entre outros. Porém é com os autores cristãos, como Justino, Irineu, Teófilo, Hipólito e Tertuliano, especialmente na disputa contra seus adversários gnósticos, como Valentino e Basílides, que o vocabulário da "gnosiologia filosófica" começa a ser utilizado sistematicamente em benefício da especulação cristã, assevera Panaccio (ibid. p. 58), por meio do qual se comparavam as palavras interiores dos homens à Palavra divina. Todavia o que estava em xeque então, sobremodo contra as investidas gnósticas, era a doutrina da Palavra de Deus que se fez carne em Jesus Cristo, o que explica a insistência dos autores cristãos — dentre os quais destacar-se-á Agostinho - em fazer uso da "psicologia humana” na interpretação da doutrina trinitária ${ }^{12}$, quer dizer, em pôr em paralelo o mecanismo das duas palavras (id. ibid. p. 67), humana e divina. No entanto, se essa dicotomia chega até Agostinho a partir da patrística

\footnotetext{
${ }^{11}$ Panaccio diz que a doutrina da "palavra no coração" (uerbum in corde) de Agostinho pode ser referida, não sem

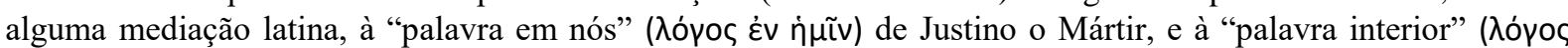

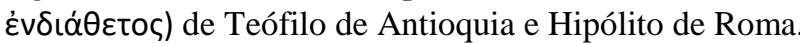

${ }^{12}$ A aplicação da psicologia dos dois lógoi, endiáthetos e prophorikós, à pessoa do Filho foi considerada perigosa em demasia para a doutrina cristã, tendo por isso merecido o anátema no sínodo de Sírmio, província romana da Panônia, atual Sérvia, em 351.
} 
grega, ainda que tenha sido de algum modo mediada pelos autores latinos, sua ascendência, em última instância, é notoriamente platônica, como se depreende inequivocamente da descrição

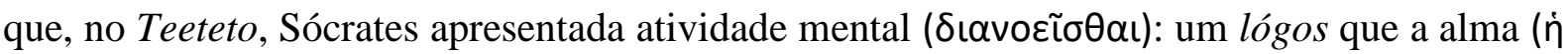

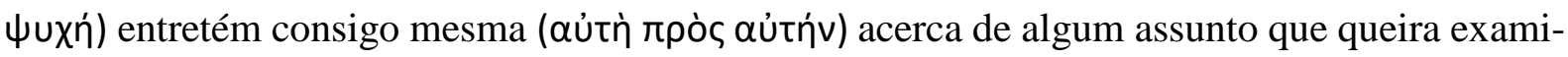
nar:

SÓCRATES - [...] pois o pensar [...] é uma palavra ${ }^{13}$ que a própria alma empreende consigo mesma acerca das coisas que queira investigar [...] pois isto é o que me parece que ela [faz], ao pensar, nada além de dialogar, ela própria questionando a si mesma e respondendo, quer assentindo, quer não assentindo. ${ }^{14}$

Portanto é assim que Sócrates imagina a alma no ato de pensar, como se praticando a

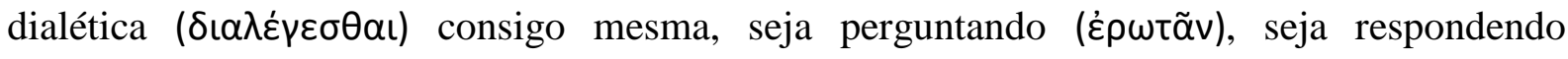

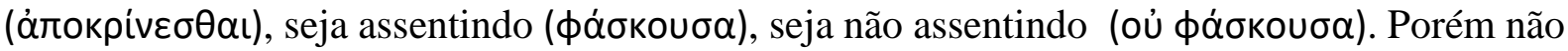
se trata de uma palavra vulgar, enunciada de viva voz (oủ $\delta \varepsilon \dot{\phi} \omega v \underline{n}$ ), como se para outro ouvinte que não o falante, mas de uma palavra silenciosa ( $\sigma \iota \vee n ̃)$, voltada exclusivamente para a própria

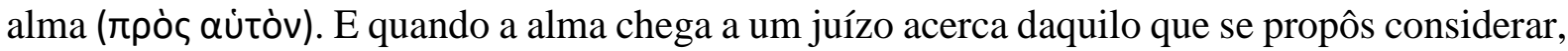

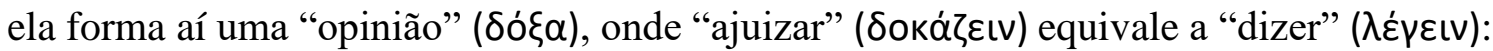

SÓCRATES - [...] Assim o ajuizar eu denomino "dizer", e o juízo, "palavra", que se diz, contudo, não para um outro, nem por meio da voz, mas em silêncio, para si mesmo. ${ }^{15}$

Duas palavras, uma interior, o pensamento, outra exterior, a fala, que, com exceção da voz ( $\phi \omega v \eta ́)$, presente nesta e ausente naquela, se equivalem perfeitamente, como se depreende também do que Platão porá na boca de um estrangeiro, no Sofista:

[263e] ESTRANGEIRO - E não são o pensamento e a palavra a mesma coisa, exceto que o primeiro é um diálogo sem voz que ocorre no interior da alma consigo mesma, esse mesmo que entre nós foi chamado de "pensamento"? [...] E aquele fluxo que procede [da alma], saindo através da boca com sons distintos, é chamado de "palavra"? [...] E, pois, nas palavras sabemos que há aquilo mesmo [...] o afirmar e o negar [...] [264a] então quando isto ocorre na alma, através do pensamento, em silêncio, tens algo que dizer disso, exceto [que se trata de] um juízo? [...] E assim, visto que a palavra

\footnotetext{
${ }^{13}$ Para efeito de análise e a despeito de sua rica polissemia, traduz-se ao longo deste texto o vocábulo grego lógos, assim como o latino uerbum, invariavelmente pelo vocábulo "palavra", cujo sentido também pode ser expandido em vernáculo para compreender os de seus equivalentes grego e latino, como "pensamento", "discurso", "razão" etc. Note-se que todas as traduções constantes deste texto, que pendem via de regra e de propósito para a literalidade, são de exclusiva responsabilidade de seu autor.

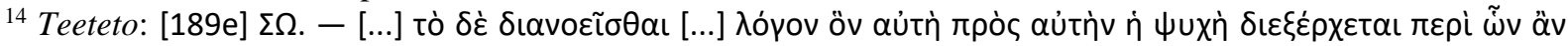

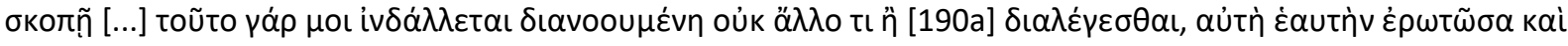

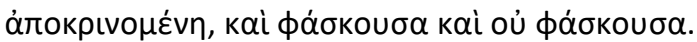

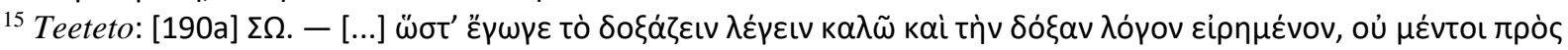

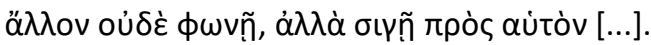


era verdadeira e falsa, e que não apenas disto se mostrou [constituir] o pensamento, mas também de um diálogo da alma para consigo mesma, e que o juízo parece ser a finalidade do pensamento... ${ }^{16}$

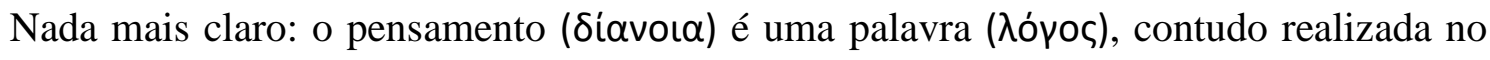

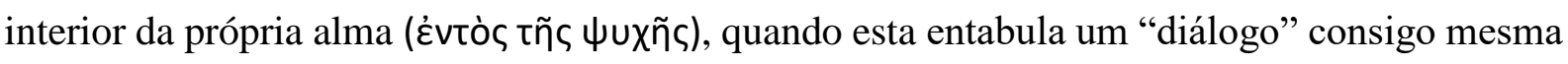

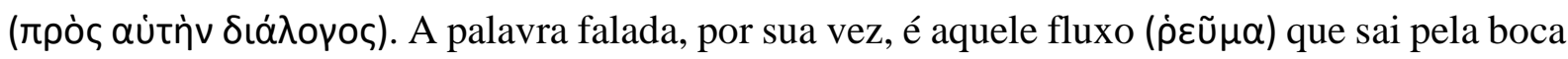

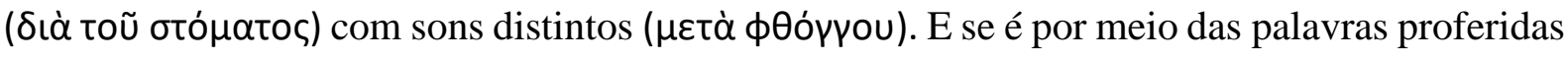

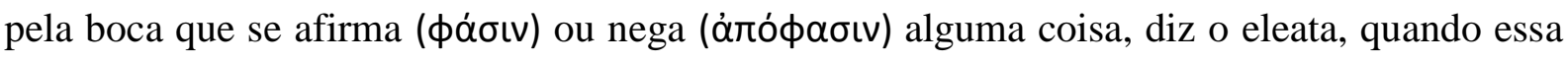
palavra ocorre silenciosamente ( $\mu \varepsilon \tau \dot{\alpha} \sigma(\gamma \tilde{\varsigma} \varsigma)$, no interior da alma (દ̉v $\psi \cup \chi n ̃ n)$, segundo aquilo que se chama de "pensamento", o que se produz nada mais é do que o juízo ( $\delta$ ó $\alpha$ ), ou opinião,

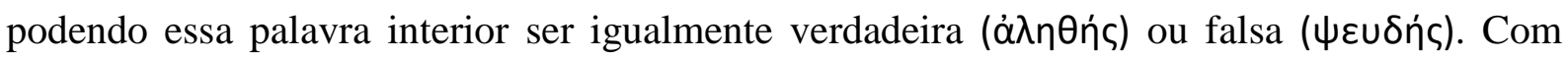
efeito, se o pensamento é um diálogo da alma consigo mesma, que, quando proferido pela voz, produz assentimento, ou não, acerca das proposições, verdadeiras ou falsas, por que no interior da alma teria estrutura diferente? Como imaginar um diálogo da alma consigo mesma que não se desse em palavras, posto que silenciosas? Demais, como seria possível formular algum juízo, que consiste em afirmações e negações, inquestionavelmente por meio de estrutura verbo-nominal, a não ser por meio de palavras, ainda que silenciosas?

Se se leve em consideração essa passagem do Sofista (263e), tarefa ousada seria recusarlhe um alto grau de identidade, entre a estrutura da palavra sonora e a da palavra silenciosa, identidade que Panaccio denomina "isomorfismo" (2017, p. 13). Com efeito, exceto pela voz ( $\phi \omega v \eta ́)$, a mesma estrutura verbo-nominal parece reproduzir-se em ambas as instâncias, excogitada e proferida. Todavia o reconhecimento desta isomorfia não é unânime, como se depreende, por exemplo, da posição de Chiesa (1992), que, negando as evidências textuais, alega que uma tal paridade não está de acordo com o espírito geral da filosofia platônica, na medida em que implicaria uma dependência do pensamento à linguagem, do inteligível ao sensorial. A conclusão de Panaccio, que parece endossar as objeções de Chiesa, é que a aplicação de categorias gramaticais ao pensamento por Platão não foi "conclusiva", visto que ele não deixou transparecer nada que pudesse ser aproveitado para uma teoria do pensamento (2017, p. 16):

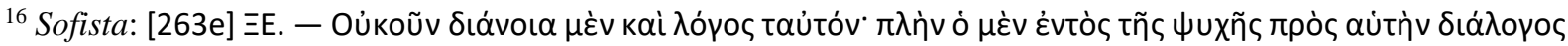

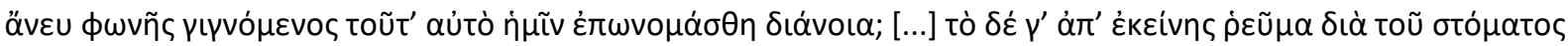

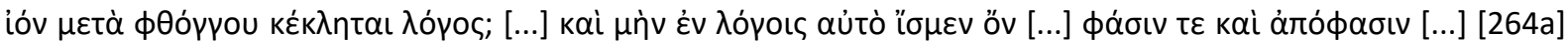

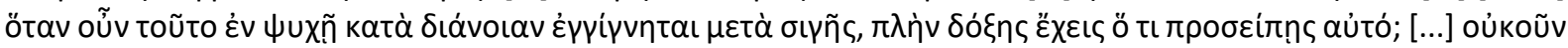

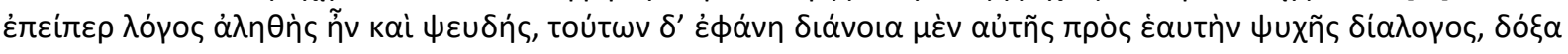

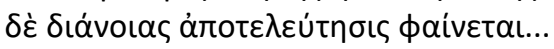


"A transferência do modelo linguístico de análise do pensamento neste passo, nem explora o princípio semântico de composição, nem a estruturação sintática".

Essa crítica parece rígida em demasia, visto supor que as preocupações do fundador da Academia fossem análogas às da novíssima filosofia do pensamento, ou da linguagem. Mas não eram, como tampouco foram as de Agostinho. Vê-se, contudo, que ainda no Sofista o estrangeiro de Eleia esclarece a estrutura do lógos — nomes (ővo $\mu \alpha)$ e verbos $(\dot{\rho} \tilde{n} \mu \alpha)$ — por meio de que se pode dizer das coisas que foram, são e serão:

ESTRANGEIRO - Então já está claro que, acerca das coisas que são, ou que estão sendo, ou que foram, ou que hão de ser, ele não apenas nomeia, mas também conclui algo, combinando verbos aos nomes. Por isso é que dissemos que ele "diz" e não apenas "nomeia", de onde ter sido para esta combinação adotado o nome de "palavra". ${ }^{17}$

Se essa palavra, estruturada discursivamente para negar ou afirmar algo, dizendo daquilo que é, foi e será, conclui alguma coisa, produzindo juízos, ela o faz indubitavelmente por meio de movimentos da razão. E isso também se chama lógos, no sentido de "discurso", ou palavra estruturada racionalmente, que deve ser, neste caso, sempre a respeito de algo (262e). Portanto, dada a paridade entre os dois lógoi, o interior, que aqui se define como diánoia, ou pensamento, e que a tradição grega chamará posteriormente de lógos endiáthetos, e o exterior, proferido pela voz, que se dirá lógos prophorikós, nenhum impedimento parece haver para que essa isomorfia se aplique a ambos. ${ }^{18}$ Assim a mesma estrutura mínima que se percebe no modelo linguístico da palavra exterior se aplica também à interior, pois, se pensamento e discurso se equivalem, como resta claro nas passagens supracitadas, sendo os discursos constituídos de pequenas unidades, nomes e verbos, o discurso mental deve estruturar-se de modo equivalente. No entanto a tradição posterior não deu muito peso a essa paridade, como se permite supor a partir da crítica contemporânea, preferindo destacar antes a disparidade entre a natureza das duas palavras, a interior e a exterior. Cabe investigar agora se de fato Agostinho nada fez senão aprofundar essa suposta disparidade, como se tem dito, ou se há algo mais que se possa depreender desse conúbio entre palavra e pensamento em seus escritos, que a crítica ainda não tenha notado com o devido cuidado.

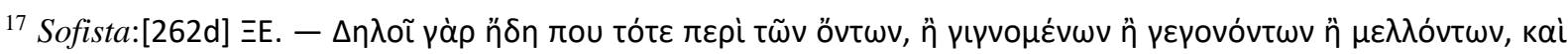

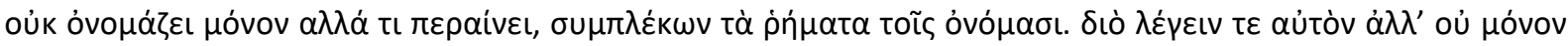

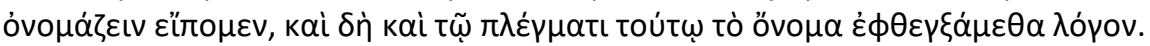

${ }^{18}$ Panaccio (2017, p. 17) nota que; Aristóteles (cf. Analíticos posteriores 76b24-26) também contrasta a demonstração que se efetua com um argumento exterior ( $(\tilde{\xi} \xi \omega \lambda$ ó̀oৎ) com uma que se produz com um argumento interior,

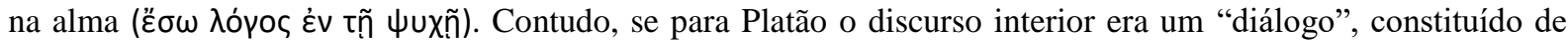
nomes e verbos, unidades menores, depois perguntas e respostas, para seu epígono, ao invés, era um processo de inferências, ou seja, de premissas e conclusões.
} 


\section{De dialectica: palavra concebida na mente}

A despeito do veto maurino ${ }^{19}$, que considerou a obra espúria, nada há no tratado De dialectica que o impeça de ser de Agostinho, diz Darrell (1975, p. 30), fundamentando cuidadosamente os "indícios positivos" que apontam para a sua autoria, por volta de 387. No que tange à questão da linguagem propriamente dita e de sua relação com o pensamento, o De dialectica tem uma relativa importância, embora seja apenas um tratado mal começado, porque os conceitos, supostamente de ascendência estoica, que o jovem autor desposa nesta obra, não tendo sido posteriormente "corrigidos", servem para estabelecer um léxico temático que servirá de guia para a leitura das passagens subsequentes. Contudo o maior interesse, como se poderá verificar adiante, respeita ao termo dicibile, que, embora não tenha sido atestado antes do autor, sugere uma provável versão do estoico $\lambda \varepsilon \kappa \tau o ́ v^{20}$. Eis o vocabulário de interesse (Dial. §5):

(1) PALAVRA (uerbum) é um signo de alguma coisa (uniuscuiusque rei signum), que pode ser compreendido pela inteligência de um ouvinte (ab audiente possit intellegi), depois de proferido por um falante (a loquente prolatum);

(2) Signo (signum) é algo que mostra a si mesmo ao sentido corpóreo (se ipsum sensui...), além de mostrar ao espírito algo que não ele (...et praeter se aliquid animo ostendit) ${ }^{21}$;

(3) COISA $(r e s)^{22}$ é aquilo que é sentido (sentitur) através do sentido corpóreo, ou compreendido pela inteligência (intellegitur);

(4) FALAR (loqui) é emitir um signo por meio de voz articulada (uoce articulata signum dare);

(5) VOZ ARTiculadA (uox articulata) é o som da voz que pode ser compreendido em letras (comprehendi litteris) ${ }^{23}$;

\footnotetext{
${ }^{19}$ Referência à Patrologia Latina, célebre edição dos beneditinos da congregação de S. Mauro, preparada por J.P. Migne em meados do séc. XIX.

${ }^{20}$ Cf. Long (2008, p. 46).

${ }^{21}$ Portanto o signo se mostra ao sentido da audição, quando soa, e mostra alguma coisa além de si, quando aponta para algo que não ele, quer dizer, quando significa.

${ }^{22}$ Trata-se, obviamente, do referente, que pode ser de natureza corpórea ou inteligível.

${ }^{23}$ Neste caso não se trata das imagens grafadas das letras, mas de seus sons apenas.
} 
(6) PALAVRA ESCRITA (in scripto) não é propriamente uma palavra (non uerbum), cuja natureza é sonora, mas o signo da palavra (uerbi signum), ou seja, signo de uma voz significante (signum significantis uocis) $^{24}$;

(7) LETRA (littera) é a menor parte da voz articulada (uocis articulata pars minima).

Definidos os termos, resta saber como se dá para o autor o processo linguístico, que neste caso refere-se primordialmente à disputa dialética, escopo da obra. Há quatro instâncias a serem consideradas:

[1] Quando uma palavra procede da boca, se ela procede por causa de si mesma, isto é, para que a respeito da própria palavra algo se questione e se dispute [dialeticamente], ela é sempre a coisa sujeita à disputa e à questão, mas a própria coisa [neste caso] chama-se "palavra". [2] Porém, tudo aquilo que, a partir da palavra, não os ouvidos, mas o espírito sente, e no próprio espírito está retido, chama-se "dizível”. [3] Mas quando uma palavra procede [da boca], não por causa de si mesma, mas por causa de significar alguma outra coisa, chama-se "dicção". [4] Porém, a própria coisa, que já não é palavra, nem a concepção da palavra na mente, quer tenha uma palavra com que possa ser significada, quer não tenha, de nada além de "coisa" é chamada, [no sentido] próprio do nome. ${ }^{25}$

Portanto, numa disputa dialética, quando uma palavra é proferida, não para significar uma coisa qualquer, e sim a si mesma, apesar de ser o próprio objeto da questão disputada, pelo fato de ser uma palavra, deve ser chamada por esse nome, "palavra" (uerbum). Porém, se é proferida para significar alguma outra coisa que não ela mesma, nesse caso diz-se "dicção" (dictio). A coisa/referente, que nem é palavra, nem dizível, nem dicção, quando considerada em si mesma, tenha ou não um nome por que seja chamada, diz-se, neste vocabulário dialético, simplesmente "coisa" (res), no sentido próprio do nome. Agora o que mais interessa aos propósitos desta investigação, o “dizível” (dicibile) — possível tradução do estoico lektón —, adjetivo substantivado cuja desinência (-bilis), implicando passividade, permite que seja compreendido literalmente como "aquilo que é passível de ser dito", é uma "palavra" (uerbum), porém que se encontra inclusa na mente (animo tenetur inclusum), pela qual é sentida — ou percebida, ou pensada, como é permitido interpretar o verbo sentire - , mas a partir da própria palavra (ex uerbo), não dos ouvidos (non aures). Porém se a palavra é voz sonante (omne uerbum sonat), e se é à

\footnotetext{
${ }^{24}$ Portanto, se a palavra é signo da coisa, a palavra escrita é signo do signo da coisa. O que se lê não são palavras, mas apenas signos das palavras (quae legimus igitur non uerba sunt, sed signa uerborum).

${ }^{25}$ De dialectica (Dial.) \$5: [1] Cum ergo uerbum ore procedit, si propter se procedit, id est, ut de ipso uerbo aliquid quaeratur aut disputetur, res est utique disputationi quaestionique subiecta, sed ipsa res "uerbum" иocatur. [2] quidquid autem ex uerbo, non aures, sed animus sentit, et ipso animo tenetur inclusum, "dicibile" uocatur. [3] cum uero uerbum procedit non propter se, sed propter aliud aliquid significandum, "dictio" uocatur. [4] res autem ipsa, quae iam uerbum non est neque uerbi in mente conceptio, siue habeat uerbum quo significari possit, siue non habeat, nihil aliud quam "res" uocatur proprio iam nomine.
} 
audição que cabe a captação das vozes, de que tipo de palavra capta a mente o dizível? Na verdade, imagina-se que a mente não "sinta" a palavra diretamente, apenas receba-lhe o percepto através do sentido da audição, percepto que é também palavra, embora silenciosa. Assim, apenas depois de captado o som pelos ouvidos, que de algum modo se fez um percepto não sonoro, é que a mente pode "sentir" a palavra, que aí, na clausura da mente, se chama "dizível”, que é também, como se pode depreender da definição de "coisa" por exclusão, uma "concepção da palavra na mente" (uerbi in mente conceptio). Com efeito, enquanto o que é captado pelos sentidos se diz "percepção" (per-capio), o que é captado pela mente talvez seja dito com mais propriedade "concepção" (con-capio). Todavia o que é captado pela mente é também, em certo sentido, por ela concebido, pois a mente não tem acesso imediato às coisas a si exteriores, e os perceptos oriundos dos sentidos do corpo não têm a mesma natureza inteligível que as coisas de que a mente é nutrida.

Resta agora saber como operam essas quatro instâncias, que se consideram distintas, nada obstante sua íntima relação, já que todas elas se dizem "palavras” (uerba):

\begin{abstract}
Portanto estas quatro coisas devem ser consideradas como distintas: palavra, dizível, dicção, coisa. [1] O que disse ser uma "palavra" não apenas é uma palavra, mas também significa uma palavra. [2] O que disse ser um "dizível” é uma palavra, contudo não significa uma palavra, mas o que é inteligido na palavra e contido no espírito. [3] O que disse ser uma "dicção" é uma palavra, mas que significa simultaneamente aquilo que aquelas duas [significam], isto é, não apenas a própria palavra, mas também o que se faz no espírito através da palavra. [4] O que disse ser uma "coisa" é uma palavra $^{26}$, que significa, além das três que foram ditas, tudo aquilo que resta. ${ }^{27}$
\end{abstract}

Se uma palavra, na qualidade de (in quantum) palavra, significa também uma palavra, como "nome", que além de ser uma palavra aponta para uma palavra, ao contrário da palavra "casa", que, sendo palavra, contudo aponta para uma coisa, ou para sua imagem mental, o dizível, esclarece Agostinho, embora seja também palavra, contudo não aponta para nenhuma palavra, mas apenas para o que é compreendido pela inteligência naquela palavra e mantém-se incluso na mente. Portanto o dizível, cuja morada é a mente silenciosa, significa um conteúdo apto para a natureza da mente, algo que é passível de intelecção, "a partir da palavra”, mas que,

\footnotetext{
${ }^{26}$ Isso porque as palavras, além de ser signos de coisas, também são coisas (ut res esse non desinant). Por exemplo, quando se fala das próprias palavras, as coisas de que as palavras são signos, neste caso, constituem também palavras (sed ipsa res uerbum uocatur). Pois não se pode falar de palavras a não ser por meio de palavras (de uerbis loqui nisi uerbis nequeamus).

${ }^{27}$ Dial. §5: Haec ergo quattuor distincta teneantur: uerbum, dicibile, dictio, res. [1] quod dixi "uerbum” "et uerbum est et uerbum significat. [2] quod dixi "dicibile" uerbum est, nec tamen uerbum sed quod in uerbo intellegitur et animo continetur significat. [3] quod dixi "dictionem" uerbum est, sed quod iam illa duo simul, id est, et ipsum uerbum et quod fit in animo per uerbum, significat. [4] quod dixi "rem" uerbum est, quod praeter illa tria quae dicta sunt quidquid restat significat.
} 
por ser contido na mente, não tem natureza sonora. Com efeito, se toda palavra propriamente dita é sonora, uma palavra retida na mente não pode ser voz, devendo ser de natureza correspondente à natureza da mente. A dicção, por sua vez, também é palavra, pois procede da boca, mas, porque o faz para significar algo que não ela, aponta não apenas para uma palavra, mas também para um dizível. De fato, a palavra "casa" pode significar uma palavra, se se trata de defini-la, como quando se indaga de suas características morfológicas, por exemplo, mas também pode significar uma coisa, a imagem mental de uma casa evocada pelo som da voz articulada, cuja natureza é inteligível. A coisa, por fim, quando proferida, é também palavra, pois não se pode dizer dela senão por meio de sons articulados; contudo, se é considerada em si mesma, a despeito da palavra com que se designe, caso exista uma, ela é apenas o que é. Com efeito, mesmo que nenhum falante existisse sobre a face da terra, ainda assim a face da terra existiria, independente da ausência de falantes. As distinções se esclarecem com o exemplo aduzido pelo filósofo, que admite a dificuldade da questão:

\begin{abstract}
Mas eu percebo que estas coisas devem ser ilustradas por meio de exemplos. Assim, supõe que um menino seja interrogado por um certo gramático do seguinte modo: "“Armas' é que parte do discurso?" Isso que foi dito, "armas", foi dito por causa de si mesmo, isto é, uma palavra por causa da própria palavra. Todavia as demais, quando diz: "que parte do discurso", não [diz] por causa delas mesmas, mas por causa da palavra que foi dita, "armas", quer tenham sido sentidas no espírito, quer proferidas pela voz. Mas se foram sentidas no espírito, antes da voz, serão "dizíveis". Porém se por causa daquilo que disse é que prorromperam em voz, aí se fizeram “dicções"... ${ }^{28}$
\end{abstract}

A palavra "armas" (arma), com que Virgílio dá início ao primeiro canto da Eneida ${ }^{29}$, está sendo considerada, neste caso, uma palavra cujos atributos gramaticais se quer conhecer. Portanto a palavra "armas" é dita em virtude de si mesma, ou seja, não significa outra coisa que não ela, na qualidade de palavra, em contraste com o restante da frase: "que parte do discurso" 30 , que, ao servir de predicado para a palavra "armas", não se diz em virtude de si mesmo. Todavia essa análise importa unicamente ao escopo dialético da obra. O que interessa apenas notar aqui é a sequência, quando Agostinho diz que essas palavras predicativas, antes de serem proferidas pela voz (ante uocem), quando apenas "sentidas" — ou concebidas — na mente, consideramse dizíveis (dicibilia); e depois que prorrompem em voz, não em virtude de si mesmas, como “armas", mas por causa dela, aí se dizem "dicções”. Vê-se que essas palavras, que constituem

\footnotetext{
${ }^{28}$ Dial. §5: Sed exemplis haec illustranda esse perspicio. fac igitur a quoquam grammatico puerum interrogatum hoc modo: "Arma' quae pars orationis est?" quod dictum est "arma" propter se dictum est, id est, uerbum propter ipsum uerbum. caetera uero, quod ait: "quae pars orationis", non propter se, sed propter uerbum, quod "arma" dictum est, uel animo sensa uel uoce prolata sunt. sed cum animo sensa sunt, ante uocem, dicibilia erunt. cum autem propter id quod dixi proruperunt in uocem, dictiones factae sunt. [...]

${ }^{29}$ Eneida 1,1: Arma uirumque cano Troiae qui primus ab oris...

${ }^{30}$ Note-se que Agostinho suprimiu o verbo copulativo em sua análise.
} 
o predicado: "que" (quae), "parte" (pars), "do discurso" (orationis), e que se denominam "dizíveis", têm estatuto distinto de "armas", pois, como tratará de detalhar no De magistro $(1,4,9)$, nem todas as palavras nomeiam coisas (non autem omnia uerba nomina). Com efeito, palavras como a conjunção "se" (si), ou a preposição "de" (ex), por exemplo, embora sejam palavras, contudo não são nomes de alguma coisa (nec tamen nomina). E isso importa, neste caso, porque permite compreender o dizível também como uerbum, uma palavra que, precisamente por não nomear alguma coisa, como a preposição “de”, é retida no espírito em seu caráter exclusivamente linguístico, ou verbal, se o queira, e cujo sentido é determinado por outras palavras do mesmo tipo, naquilo que se pode compreender como sendo um conceito, e dos mais abstratos, pois uma preposição liga uma palavra à outra, contudo atribuindo a essa relação ainda um sentido, seja de natureza espacial, como "direção para", ou "direção a partir de", ou "lugar onde" etc., seja de outra natureza qualquer, dela derivada e ainda mais abstrata ${ }^{31}$. E esses sentidos tampouco se compreendem sem o recurso a outras palavras, que também descrevem posição e movimento no espaço, neste caso, por meio de signos de caráter semelhante, quer dizer, que tampouco nomeiam qualquer coisa. O que se está dizendo aqui, em suma, é que não é possível compreender o dizível como apenas imagem de coisas, como se o pensamento fosse de uma natureza, diga-se, pictórica, e aquilo que sai da boca, de outra. O exemplo segue:

[...] Agora o próprio [termo] “armas”, que aqui é uma palavra, quando foi pronunciado por Virgílio, foi uma "dicção". Pois não foi proferida por causa de si mesma, mas para que por meio dela fossem significadas, quer as batalhas que travou Eneias, quer o seu escudo, quer os restantes [armamentos] que Vulcano fabricou para o herói. Agora as próprias batalhas, ou armas, que foram travadas, ou carregadas por Eneias - as próprias, digo, que eram vistas, visto que fossem travadas e existissem, e que, se agora estivessem presentes ou pudéssemos mostrar com o dedo, ou tocar, as quais, ainda que não fossem pensadas, contudo nem por isso se dá que não tenham existido -, portanto essas próprias, [consideradas] em si mesmas, nem são palavras, nem dizíveis, nem dicções, mas coisas, que agora se chamam "coisas" [no sentido] próprio do nome. ${ }^{32}$

Se fosse possível ouvir o primeiro verso da Eneida cantado pelo próprio Virgílio, atendose ao significado da palavra "armas", que aponta para algo que não ela, tem-se o que Agostinho chama aqui de "dicção", termo esse que não será explorado no futuro. Nesse caso resta claro

\footnotetext{
${ }^{31}$ Por exemplo, quando se diz que uma espada é "de" bronze, a preposição aqui não indica origem espacial, mas a matéria-prima "a partir de que" a espada foi feita.

${ }^{32}$ Dial. §5: [...] ipsum uero "arma" quod hic uerbum est, cum a Vergilio pronuntiatum est, dictio fuit. non enim propter se prolatum est, sed ut eo significarentur uel bella quae gessit Aeneas uel scutum uel cetera quae Vulcanus heroi fabricatus est. ipsa uero bella uel arma, quae gesta aut ingestata sunt ab Aenea - ipsa, inquam, quae, cum gererentur atque essent, uidebantur, quaeque si nunc adessent uel digito monstrare possemus aut tangere, quae etiamsi non cogitentur non eo tamen fit ut non fuerint - ipsa ergo per se nec uerba sunt nec dicibilia nec dictiones, sed res quae iam proprio nomine "res" uocantur.
} 
que "armas" significa algo outro que não a palavra, coisas (res) que, houvessem ou não sido nomeadas, existiriam mesmo assim. E isso, ainda que se compreendam, não os armamentos, mas as batalhas travadas por Eneias, visto que o termo é polissêmico.

Pois bem, para efeito desta análise, o que se permite depreender dessa obra de juventude, que mal foi começada por Agostinho, é, antes de mais, que tanto o dizível como a palavra falada se dizem "palavras". Com efeito, a palavra prorrompe por meio de voz articulada que sai da boca, sendo falada por um falante e ouvida por um ouvinte, em virtude de ser sonante. Por sua vez o dizível não apenas está incluso no próprio espírito, mas também é por ele sentido, jamais pelos ouvidos; porém é sentido a partir da palavra (ex uerbo) — ou seja, a partir do som captado pelos ouvidos e de algum modo tornado percepto não sonoro, embora isso não tenha sido esclarecido na obra. E se uma palavra pode significar a si mesma, na qualidade de palavra, ou algo que não ela, o dizível, por sua vez, não significa uma palavra, mas apenas o que é inteligido na palavra e contido no espírito, quer dizer, não aponta para outra palavra, mas para o que ela significa, seja o que for. No entanto, se há uma distinção necessária entre as duas palavras, o fato de a palavra falada ser produzida na boca, onde se faz voz, e de onde prorrompe para os ouvidos de algum ouvinte, enquanto a palavra dizível ser concebida na mente, a partir de uma palavra, antes que se faça voz, há uma paridade inegável, para além de ambas se dizerem "palavras", o fato de que o dizível é concebido no espírito ex uerbo, "a partir de uma palavra", seja o que for que com isso Agostinho tenha pretendido implicar. Nada mais que isso se pode afirmar sem incorrer em temeridade, ao menos pela leitura do De dialectica. Talvez outro tratado de juventude, o De magistro, tenha algo mais a oferecer.

\section{De magistro: imagens mentais}

Dois são os motivos por que falam os homens (duas loquendi causas): ou ensinar, ou recordar (De magistro [Mag.] 1,1); e mesmo que Deus não careça de nenhum dos dois, nem de ser ensinado acerca dos desejos e necessidades humanos, muito menos rememorado acerca de nada que lhes respeite, ainda assim Cristo recomendou a prece (Mt 6,6) para uma "câmara cerrada" (clausis cubiculis), significando os recessos da mente, porque Deus deve ser buscado e ajuda lhe deve ser deprecada pela alma racional, no homem interior (homo interior), como salmodiou o profeta, exortando a que se falasse "no coração" (dicite in cordibus) (S1 4,5). Portanto, mesmo que a prece não tenha necessidade da fala (locutio), quer dizer, de palavras que reverberem nos ouvidos (sonantibus uerbis), isso não significa que nenhuma necessidade há de 
palavras de outra natureza, como as do coração, as quais, quando o crente ora em silêncio, "vibram" apenas em sua mente. E aos que objetassem que os sacerdotes oram em voz alta, se lhes replicaria que o fazem não porque Deus tenha necessidade das palavras audíveis para atender as preces da assembleia, mas apenas por causa de significar os conteúdos de sua própria mente (significandae mentis suae causa) (Mag. 1, 2). Do mesmo modo o Mestre supremo (summus magister) teria ensinado as palavras da oração dominical (Mt 6, 9-13), não porque as palavras audíveis fossem essenciais, como se fosse necessário falar ao orar, mas por causa de significar o conteúdo nelas representado $(\text { Mag. } 1,2)^{33}$, ou antes, a fim de que por meio das palavras audíveis os discípulos pudessem rememorar a quem deviam deprecar e por que o faziam, quando entrassem nos recessos de suas almas para fazê-lo.

Pois bem, se aquele que fala expressa sua vontade por meio de sons articulados com significado ${ }^{34}$, cabe aqui indagar do lugar e do modo dessa articulação, quer dizer, onde e como se dá a passagem da palavra silenciosa à palavra sonora. Talvez o lugar no homem interior onde Agostinho diz que se deve deprecar ajuda a Deus, nos cubículos secretos da alma racional, sirva de farol para iluminar o caminho. Com efeito, parece que nenhuma outra faculdade humana, exceto a razão, seria capaz de fazer essa tradução entre as duas palavras, porque a boca, ainda que sirva de instrumento para duas tarefas distintas, a produção dos sons e a captação dos sabores, contudo, por ser de natureza corpórea, não é apta a fazê-lo. Ora, que Agostinho imaginasse que a mente pensava a própria coisa e que as vozes saíam da boca já articuladas, pelo intermédio das papilas gustativas, isso seria menoscabar-lhe por completo a inteligência ${ }^{35}$. Ao que parece, na esteira da concepção platônica supra-apresentada, que via o pensamento como um diálogo interior da alma consigo mesma, Agostinho se permite também essa perspectiva,

\footnotetext{
${ }^{33}$ Adeodato defende a princípio que, ao ensiná-los o Padre-nosso, Cristo não ensinou palavras aos discípulos (non enim uerba), mas as próprias coisas por meio de palavras (sed res ipsas eos uerbis docuit). Essa, na verdade, é uma das críticas que se fazem à concepção de linguagem de Agostinho, que as palavras são instrumentos pelos quais se comunicam as próprias coisas (res ipsas), ao contrário do que se propugna por dizer hoje, que aquilo que se comunica é indissociável das palavras com que ele é pensado e dito. A questão não é nada simples, muito menos pacífica, especialmente se se objete que o Padre-nosso, seja ele orado em que língua for, será sempre o mesmo, quer dizer, sua substância não será alterada pela língua em que for praticado, seja grego, seja latim, assim como o conteúdo de uma obra, por mais se deparem "dispersos" nela alguns "lapsos de intraduzibilidade", no dizer de Ricoeur (2011, pp. 24-25), restará basicamente o mesmo em qualquer língua, como a prática o tem demonstrado, à revelia da teoria. Daí o próprio Ricoeur ter dito, parafraseando o filósofo analítico Donald Davidson, com respeito à tradução: "teoricamente incompreensível, mas efetivamente praticável," (Ibid. p. 37).

${ }^{34}$ De magistro (Mag.) 4,9: "ut uerbum sit quod cum aliquo significatu articulata uoce profertur.

${ }^{35}$ Essa dúvida respeita apenas ao dizível, aos conteúdos que se submetem ao pensamento cognitivo, mas há muito mais nas atividades da mente do que apenas silogismos ou proposições constituídas de nomes e verbos, para não dizer do "inefável", que jamais poderia ser submetido às limitações impostas pela linguagem humana, como já Wittgenstein parece ter reconhecido no Tractatus (6.522), ainda que de modo um tanto enigmático, ao admiti-lo (Es gibt allerdings Unaussprechliches), inefável que, sendo o místico (das Mystische), apenas "se mostra" (zeigt sich), e acerca de que, não podendo ser dito (Wovon man nicht sprechen kann), é melhor calar-se (darüber mu $\beta$ man schweigen) (Tractatus L.-P. §7).
} 
contudo com objetivo bem outro, demonstrar que as palavras sonoras nada ensinam em si mesmas.

[...] se alguém argumente que, ainda que não publiquemos nenhum som, contudo, porque pensamos as próprias palavras, nós falamos interiormente no espírito, e que assim também, por meio da fala, nenhuma outra coisa fazemos do que recordar, visto que a memória, a que aderem as palavras, ao revolvê-las, faz vir à mente as próprias coisas de que as palavras são signos. ${ }^{36}$

Mesmo que alguém queira contender, num claro eco platônico, posto que distante, que, quando se pensa, em silêncio, fala-se interiormente, no espírito, ainda que não seja produzido nenhum ruído, ainda assim, contra-argumenta Agostinho, essas palavras mentais não servem para ensinar nada, apenas para recordar. À parte a tese proposta por ele no De magistro ${ }^{37}$, que segundo o interessante artigo de Burnyeat (1987) tem sido pouco, a não dizer mal compreendida, o que interessa na passagem para os propósitos deste artigo, e que tem sido adrede desprestigiado nas análises que se fazem de seu pensamento acerca da linguagem, é a ideia de que "pensamos as próprias palavras" (ipsa uerba cogitamus). E mesmo que se diga que se trata aqui apenas de uma suposição, ecoando, quem sabe, um platonismo distante, quando diz que se fala interiormente (intus loqui) no espírito, suposição que não está de modo algum sendo negada por ele, o fato é que Agostinho considera essa modalidade de discurso interior como "fala", tratando-a como pertencente a estatuto semelhante ao da palavra vocal, cuja função, também neste caso silencioso, nada mais é do que recordar. E o interesse não se limita a isso, pois recordar, nesse caso, diz Agostinho, implica revolver as palavras que residem na memória, no interior da qual estão aderidas, fazendo, por meio dessa "revolução", com que venham à mente as coisas - ou suas imagens mentais, como ficará claro nas passagens que serão analisadas na sequência - de que as palavras constituem signos. Se de um lado nenhuma outra potência cognitiva da alma poderia ser mais capacitada para efetuar esse "revolver" das palavras do que a razão, de outro tem-se o reconhecimento de que não são coisas, mas palavras que se mantêm armazenadas na memória, de onde são retiradas, como quem as buscasse num dicionário virtual — por que não?! — para serem manipuladas pela mente racional, quando esta produz os

\footnotetext{
${ }^{36}$ Mag. 1,2: [...] etiamsi quisquam contendat, quamuis nullum edamus sonum, tamen quia ipsa uerba cogitamus, nos intus apud animum loqui, sic quoque locutione nihil aliud agere quam commonere, cum memoria cui uerba inhaerent, ea reuoluendo facit uenire in mentem res ipsas quarum signa sunt uerba.

${ }^{37}$ Cf. Mag. 10,34. O objetivo no De magistro é provar que nada de fato se aprende através das palavras: per ea signa, quae uerba appellantur, nos nihil discere. E mesmo que se aprendam as palavras, diz Agostinho, contudo não se aprendem as coisas por elas significadas. Com efeito, quando se ouvem os sons das duas sílabas da palavra "maçã", só se vê uma imagem de maçã na mente se uma maçã já houver sido antes vista, do contrário nada poderia ser formado na mente. Grosso modo é isso o que ele quer demonstrar, e de modo nenhum que seja possível pensar sem palavras.
} 
conteúdos que lhes são próprios, segundo sua capacidade e atribuição. Logo, se se retira da memória, depois de revolvidos ali os seus conteúdos incontáveis, uma palavra qualquer, para que possa constituir um argumento, a ser construído pela mente racional, essa palavra, ao ser manipulada, o fará não apenas como significante, mas também através de seu significado. De fato, não é apenas a palavra em sua forma articulada, ainda que silenciosa, que resta armazenada na memória, mas também aquilo que ela significa, seja o que for.

Portanto essa fala interior faz vir à mente racional, a partir do repositório da memória, as próprias palavras, que, embora silentes, constituem signos de $\operatorname{coisas}^{38}$, a fim de que sejam utilizadas pela mente racional, sendo nela - é lícito supor! — ordenadas sintaticamente como matéria-prima dos tecidos linguísticos, para que prorrompam em sequência linear pela boca do falante. Porém a mente, ao fazer uso das palavras, não é apenas com elas que trabalha, mas com as coisas que elas significam, com os conteúdos para os quais apontam, cujas imagens mentais são evocadas pelas palavras, caso não se constituam das próprias palavras, imagens que se ajustam e ordenam ao conteúdo que se quer comunicar. Todavia é de se supor que não sejam imediatamente as imagens sobrepostas, nem justapostas, quer vertical, quer horizontalmente, a matéria-prima de que a mente racional se utiliza para confeccionar os discursos, e sim os signos, os quais se encaixam, segundo as regras do sistema linguístico utilizado pelo pensante, uns aos outros, permitindo que se teçam as tramas discursivas.

Mas como chegou à memória aquilo que ali se encontra incluso, a fim de ser revolvido e processado pela mente racional? Num primeiro momento, sem dúvida a partir dos ouvidos, pois tudo o que é proferido por meio de voz articulada com algum significado reverbera no ouvido para que seja sentido; apenas depois é que esse som é mandado para a memória, para que, a partir dali, possa vir a ser conhecido pela mente racional (Mag. 5,12). Portanto, quando uma palavra é falada, duas coisas acontecem: primeiro um som articulado com algum significado é proferido e toca os ouvidos de alguém, onde é sentido; depois essa voz articulada e significante que se insinuou pelos ouvidos é levada de algum modo até a memória, porém não como som, pois as propriedades físicas são incompatíveis com a natureza inteligível da memória, mas apenas sua imagem mental, por assim dizê-lo, para dali ser revolvida pela mente racional. Todavia, se os signos se constituem de som (sonus) e de significado (significatio) (Mag. 10,34), parece evidente que, não podendo os sons de natureza corpórea habitar a memória, aquilo que para lá é enviado deverá constituir-se de algo distinto, quiçá como a sinestésica "imagem acústica" de

${ }^{38}$ Os referentes, que no De dialectica se diziam simplesmente res, "coisas", no De magistro se dizem significabiles, "significáveis", coisas que podem ser significadas por signos, mas que não são signos (cf. Mag. 4,8): ea quae signis significari possunt et signa non sunt. 
Saussure (2006, pp. 79-81) ${ }^{39}$. E já que as palavras chegam até a memória, ou chegam íntegras, por assim dizê-lo, contudo apenas em sua versão mental, como imagens dos respectivos sons e das correspondentes letras em que se constituem (Mag. 5,14), ou como imagens de seus significados. Porém, se se dispam as palavras de suas articulações, quer sonoras, quer mentais, se as estará despindo de sua forma, o que fará com que deixem de ser palavras. De fato, se chegasse à memória apenas o seu significado, a imagem daquilo a que se remete, talvez isso já não fosse mais palavra, apenas a coisa significada, ou uma imagem do significável. Se assim fosse, ao ser levada para a mente racional para aí ser "revolvida", como diz Agostinho, deveria ser, na própria mente, revestida de sua forma original, quer dizer, imagem acústica articulada, do contrário não chegaria à boca como palavra, a não ser que se supusesse que a própria boca fosse a responsável pela tradução do significado em significante. Demais, seria esdrúxulo imaginar que os processos cognitivos da mente racional, como argumentos constituídos de premissas e conclusões, por exemplo, ou os nomes e verbos mencionados nos diálogos platônicos, fossem de outra natureza qualquer que não a verbal. Seja como for, era preciso indagar ainda da natureza dessa imagem mental, como Agostinho parece ter percebido.

[...] quando se procura saber, não dessas coisas que estamos sentido presentemente diante de nós, mas destas que sentimos algum tempo antes, não estamos falando agora das próprias coisas, mas das imagens impressas a partir delas e mandadas para a memória; coisas que, de que modo podemos dizer serem verdadeiras, quando vemos [serem] falsas, isso eu ignoro por completo, a não ser porque nós narramos não as coisas que estamos vendo e sentindo, mas o que vimos e sentimos... ${ }^{40}$

As coisas que são percebidas pelos sentidos corpóreos, quando presentes diante deles, produzem um conhecimento que, ao menos para o senciente, é tido por inquestionável. Todavia, querendo comunicá-las a outrem, ou meditar a seu respeito, aquele que outrora as sentiu deve contentar-se com algo distinto, espécie de cópia da coisa percebida, uma imagem (imago) que,

\footnotetext{
${ }^{39}$ Em seu Cours de linguistique générale, Ferdinand de Saussure diz que o signo linguístico não une uma coisa a uma palavra, mas um "conceito" a uma "imagem acústica", a qual se distingue das ondas sonoras, "coisa puramente física", sendo antes uma "impressão" (empreinte) de natureza psíquica desse som, segundo a representação que dele nos fazem os sentidos: "O caráter psíquico de nossas imagens acústicas aparece claramente quando observamos nossa própria linguagem. Sem movermos os lábios nem a língua, podemos falar conosco ou recitar mentalmente um poema." Note-se que o conceito e a imagem acústica em que o signo linguístico é decomposto se designam, respectivamente, "significado" e "significante" (ibid. p. 81). O que impressiona, contudo, é a surpreendente semelhança com o que diz Agostinho aqui e no De trinitate, pois o próprio termo "imagem" (imago) parece que dali foi tirado; isso, a não dizer do exemplo de leitura interior de um poema e de considerar a palavra falada a realização da imagem interior no discurso. Demais, o signo saussuriano, bipartido entre imagem acústica e conceito, parece ecoar o agostiniano, que também se subdivide em duas partes: som articulado (uox articulata) e significado (significatu), o que parece servir tanto para o signo vocal quanto para a sua imagem mental.

${ }^{40}$ Mag. 13, 39: [...] cum uero non de iis quae coram sentimus, sed de his quae aliquando sensimus quaeritur, non iam res ipsas, sed imagines ab iis impressas memoriaeque mandatas loquimur; quae omnino quomodo uera dicamus, cum falsa intueamur, ignoro, nisi quia non nos ea uidere ac sentire, sed uidisse ac sensisse narramus...
} 
embora formada a partir da própria coisa anteriormente percebida, lhe está apenas impressa em algum lugar da alma, como um sinete, que, tendo depois da percepção sido enviado para a memória (memoriaeque mandatas), ali encontra-se à disposição para ser contemplado. Essas imagens, diz Agostinho, não sem uma surpreendente dose de empirismo, ainda que formadas a partir de uma experiência verdadeira, pelo fato de não serem a própria coisa sentida, seriam consideradas irremediavelmente falsas, não fossem relatos de experiências verdadeiras, de coisas percebidas com os sentidos:

[...] Assim gestamos aquelas imagens nos recessos da memória, como documentos das coisas anteriormente sentidas, das quais, ao contemplá-las com o espírito, de boa consciência não mentimos quando falamos. Mas nós é que possuímos esses documentos, pois aquele que ouve, se as sentiu e presenciou, não aprende das minhas palavras, mas as reconhece, carregando também ele as suas imagens consigo. Porém, se não as sentiu, quem não compreenderia que crê nele ao invés de aprender de suas palavras ${ }^{41}$

Porém essas imagens, que se encontram armazenadas nos escaninhos da memória para serem contempladas pelo espírito, mesmo que se constituam para seu proprietário provas documentais (documenta) das experiências vividas, para os demais todos, que apenas ouvem os relatos que a partir delas se constroem, com suposta boa consciência, servem apenas de testemunhos, visto que, segundo a proposta do De magistro - que pouco interessa aos propósitos específicos desta investigação - nada se aprende pelas palavras ${ }^{42}$.

E se foram até certo ponto situadas e seu caráter documental determinado, posto que superficialmente, muito pouco ainda se pode arriscar a respeito dessas imagens mentais, além de estarem à disposição da mente racional e do intelecto para serem contempladas ${ }^{43}$, e da possibilidade de serem verbais, quer dizer, terem natureza linguística, visto que o espírito "revolve" as palavras que foram confiadas à memória, com as quais se podem tecer discursos ${ }^{44}$. No fim, a

\footnotetext{
${ }^{41}$ Mag. 13,39: [...] ita illas imagines in memoriae penetralibus rerum ante sensarum quaedam documenta gestamus, quae animo contemplantes bona conscientia non mentimur cum loquimur. sed nobis sunt ista documenta, is enim qui audit, si ea sensit atque adfuit, non discit meis uerbis, sed recognoscit, ablatis secum et ipse imaginibus. si autem illa non sensit, quis non eum credere potius uerbis quam discere intelligat?

${ }^{42}$ Burnyeat (1987) sustenta que o conhecimento a que se refere Agostinho, quando afirma que nada se aprende através das palavras, não se confunde com a autoridade, objeto da fé. Se as coisas podem ser comunicadas entre pessoas, o verdadeiro conhecimento é dom de Deus. Todavia, pondera (id. ibid. p. 21), se o conhecimento de $p$, como queriam acadêmicos e peripatéticos, não prescinde das relações entre $p$ e toda uma série de proposições, o que subentende uma "apreensão sinótica de toda uma área do saber", a fim de que se chegue ao conhecimento, é possível dizer que Agostinho e Wittgenstein estivessem de acordo neste sentido, visto que ninguém pode atingir a compreensão em lugar de outrem, já que a internalização das requeridas "conexões", em que o verdadeiro conhecimento se constitui, é tarefa única e exclusiva do sujeito pensante e não pode ser ensinada de fora. Portanto, neste sentido, Agostinho está com a razão: o conhecimento não se comunica por meio de palavras, de fora para dentro. ${ }^{43}$ Mag. 12,40: cum uero de iis agitur quae mente conspicimus, id est, intellectu atque ratione...

${ }^{44}$ Mag. 13,43: "e ele não tece alguma outra coisa, ao revolver no espírito as palavras enviadas à memória..." (nec aliud aliquid uoluens animo mandata memoriae uerba contexit...).
} 
grande dificuldade em distinguir a natureza dessas operações cognitivas da mente racional parece derivar do tempo, quer dizer, de sua exiguidade, visto que entre o momento da fala (tempus locutionis) e o do pensamento (tempus cognitionis) que a precede, observa com acuidade Agostinho, "nenhuma demora se interpõe", sendo praticamente instantânea a conversão da palavra interior à palavra exterior (inter tempus locutionis et tempus cognitionis nulla mora interponitur) $\left(\right.$ Mag. 14,45) ${ }^{45}$.

No entanto o interesse do De magistro não se limita apenas às duas primeiras questões apresentadas no início deste artigo, da relação da linguagem com o mundo e com o pensar, mas também implica a terceira, a questão da universalidade dos conteúdos, que, ao sugerir a existência de uma estrutura anterior à linguagem, serve de sustento para a tese da traduzibilidade desses mesmos conteúdos. A que lhe é contrária, a tese da intraduzibilidade, como explica Ricoeur (2011, p. 38), tornou-se "obrigatória" a partir dos estudos etnolinguísticos de Whorf e Sapir" $^{46}$, que sublinharam "a impossibilidade de sobreposição dos diferentes recortes sobre os quais repousam os múltiplos sistemas linguísticos”, quer fonéticos, quer fonológicos, quer sintáticos. Mas a intraduzibilidade dos conteúdos foi só o começo visto sua consequência ter extrapolado o âmbito linguístico, como se percebe pelo estudo de Benveniste já citado, que advoga a ideia de que "cada recorte linguístico impõe uma visão de mundo" distinta, resultando daí a tese - reputada insustentável por Ricoeur (2011, p. 38) — de que as cosmologias gregas se permitiram elaborar a partir da polissemia de seu verbo "ser" (عĩvaı) ${ }^{47}$.

\footnotetext{
${ }^{45}$ Essa nulla mora entre o tempo do pensar e o do dizer equivale ao caráter dito "inconsciente" das operações mentais precedentes da fala, como apontou Benveniste (1966, p. 63); inconsciência esta, segundo ele, a responsável pela dissociação histórica entre o pensar e o falar.

${ }^{46}$ Cf. Carroll, op. cit., 2011.

${ }^{47}$ Para Benveniste (1966, p. 66) as categorias de Aristóteles (1b25-27) eram exclusivas da língua grega, na qual ele pensava, e de modo nenhum categorias universais. Daí ter relacionado: A SUBSTÂNCIA (oủoía) à classe linguís-

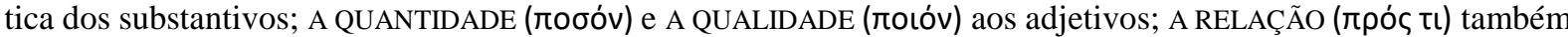

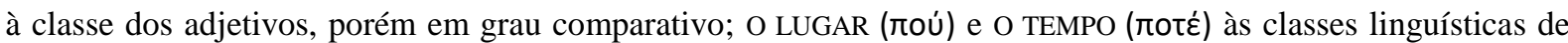

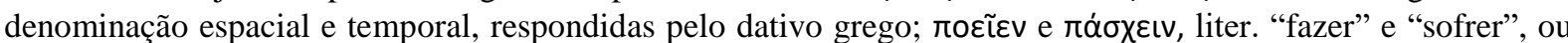

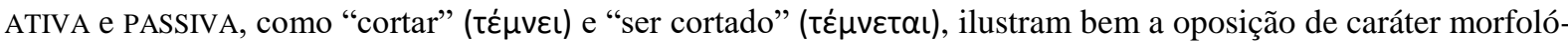
gico pretendida entre as vozes verbais; кعĩ $\theta \alpha \mathrm{l}$, literalmente ESTAR DEITADO (situm esse), expressa por um verbo da voz "média", denotava uma maneira de ser tão característica como as expressas pelas vozes ativa e passiva, e que era mais importante do que a voz passiva, que dela derivava. Por fim a categoria ह̌xદıv, POSSUIR, não deve ser compreendida como uma posse material, mas estar num certo estado, o que o latim verteu por habitus. Para Benveniste, portanto, apesar de ter desejado estabelecer os atributos dos objetos, ao elencar os predicados possíveis da proposição, isoladamente, isto é, sem combinação ( $\sigma u \mu \pi \lambda$ okń), Aristóteles não fez senão estabelecer os "seres linguísticos" (1966, p. 70). E pelo fato de as categorias referirem-se à estrutura de uma língua particular, não se pode dizer que representem condições gerais e permanentes, mas apenas "projeções conceituais de um determinado estado linguístico". Daí que, acima de todos os predicados elencados, reside a noção de "ser", que nada mais é do que uma "propriedade linguística específica". O verbo grego eĩval, "ser", "estar", "existir", sentencia o linguista francês, não é uma necessidade de todas as línguas; sua função copulativa, que serviu à proposta lógica do filósofo, se emparelhava com sua função nominal, quando podia ser considerado como uma "coisa", fosse em posição subjetiva, fosse em posição predicativa. Esses empregos todos do verbo عivaı em suas mais variadas
} 
Pois bem, deixando de parte a questão derivada da traduzibilidade, ou sua tese contrária, importa notar aqui, a partir da passagem do De magistro apresentada abaixo, não apenas a impressionante atualidade das questões tratadas por Agostinho nesta obra de juventude, mas acima de tudo o argumento da universalidade dos conteúdos, que serve de sustentáculo para sua visão acerca da linguagem, a qual não deve ser destacada de suas concepções espirituais e filosóficas, como se propugnará por mostrar na sequência:

[...] em todas as partes do discurso algo é significado, e daí é chamado; porém se é chamado também é nomeado; se é nomeado, sem dúvida é nomeado por um nome, o que se julga com facilidade nas mais diversas línguas, pois quem não vê, se procuras aquilo que os gregos nomeiam o que nomeamos "quem", responde-se tís; aquilo que os gregos nomeiam o que nomeamos "quero", responde-se thélō; aquilo que os gregos nomeiam que nós nomeamos "bem", responde-se kalôs; aquilo que os gregos nomeiam o que nós nomeamos "escrito", responde-se tò gegramménon; aquilo que os gregos nomeiam que nós nomeamos "e", responde-se kaí; aquilo que os gregos nomeiam que nós nomeamos "de", responde-se apó; aquilo que os gregos nomeiam o que nós nomeamos “ai!", responde-se oí; e em todas estas partes dos discurso, que agora enumerei, fala com retidão aquele que assim interrogue $[\ldots] .^{48}$

Por meio desse breve estudo comparativo entre as línguas grega e latina, Agostinho parece estar advogando a tese de que não importa o nome que se dê às coisas, visto que, seja em qual língua for, elas serão simplesmente o que são. Assim, para o pronome interrogativo latino quis, "quem”, há o grego tíc; para o verbo uolo, "eu quero", há o correspondente grego $\theta \varepsilon ́ \lambda \omega$;

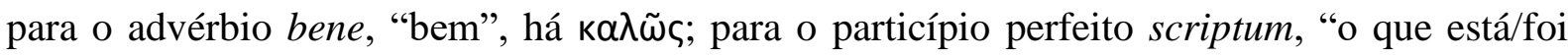

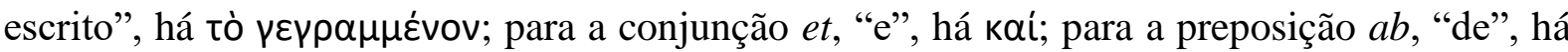
áró; para a interjeição heu, “ai!”, “oh!”, há a partícula grega oỉ. Portanto, das classes de palavras todas, que os antigos diziam partes orationis, "partes do discurso" 49 , independentemente

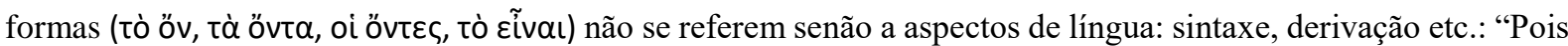
é dentro de uma situação linguística de tal modo caracterizada que pode nascer e se desenvolver toda a metafísica grega do 'ser', as magníficas imagens do poema de Parmênides, assim como a dialética do Sofista" (id. ibid., p. 71). Daí a conclusão que a particularidade, que é das línguas de derivação indo-europeia, com respeito ao verbo "ser", não é de modo nenhum universal, nem uma condição necessária, e procurar buscar no sistema formal de uma determinada língua o decalque de uma "lógica" inerente ao espírito, assevera Benveniste, "exterior e anterior à língua", nada mais faz do que conduzir a ingenuidades e tautologias.

${ }^{48}$ Mag. 5,15: [...] omnibus partibus orationis significari aliquid, et ex eo appellari; si autem appellari et nominari; si nominari, nomine utique nominari: quod in diuersis linguis facillime iudicatur. quis enim non uideat, si quaeras quid Graeci nominent quod nos nominamus "quis", responderi tíc; quid Graeci nominent quod nos nominamus

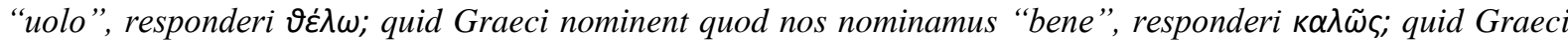

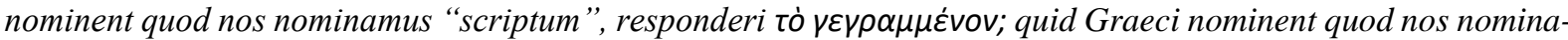
mus "et", responderi kaí; quid Graeci nominent quod nos nominamus "ab", responderi áró; quid Graeci nominent quod nos nominamus "heu", responderi ol"; atque in his omnibus partibus orationis, quas nunc enumeraui, recte loqui eum qui sic interroget...

${ }^{49}$ Nada obstante sua pouco provável autenticidade, a edição abreviada do tratado De grammatica, constante do apêndice do primeiro tomo das obras de Agostinho editadas pelos beneditinos da congregação de S. Mauro (PL 32), considera as seguintes partes do discurso: nomina; pronomina; uerba; aduerbia; coniunctiones; praepositiones; interiectiones; participia. Agostinho deixa de parte a categoria nomen na passagem supracitada 
da língua em que se expressem, seja grega, seja latina, tem-se uma só e mesma coisa para cada uma, quer dizer, o mesmo referente, o que é veementemente rechaçado pela ciência da linguagem, ao menos desde o século XX. Isso contudo não desmerece o argumento da traduzibilidade, como também tem sido comprovado ao longo da história da humanidade, visto que obras têm sido traduzidas, intérpretes permitem a comunicação entre estrangeiros, leis internacionais se estabelecem e se fazem seguir pelos falantes das mais distintas línguas etc. A questão, nada simples, penda para o lado que se queira fazê-la pender, importa aqui por motivo bem outro, que extrapola em muito a questão da traduzibilidade, como se tratará de esclarecer a partir de agora.

O objetivo de Agostinho no De magistro, consoante com sua proposta filosófica de toda uma vida, para muito além dos interesses linguísticos ou cognitivos que hoje movimentam as filosofias da linguagem e do pensamento, era, acima de tudo, demonstrar o status inferior, mas não especificamente da linguagem em relação ao pensamento, e sim da natureza sensível em relação à inteligível, quer dizer, do corpo em relação ao espírito. Assim, se as palavras sonoras, ou vozes, têm natureza física, visto constituírem-se de sons captáveis pelo sentido corpóreo da audição, era indubitável que sua substância fosse algo de estatuto inferior ao da palavra que se concebe no espírito, necessariamente de natureza inteligível, ou espiritual. Isso porque o espírito, ou mente, princípio inteligente do homem, feito à imagem e semelhança de Deus, é o que mais se aproxima nele da natureza divina incorruptível, pois, ao contrário do que Agostinho houvera imaginado durante sua adolescência ${ }^{50}$, muito provavelmente sob influência do materialismo estoico, Deus era espírito ${ }^{51}$. E como consequência imediata e necessária dessa superioridade do espírito em relação ao corpo, mas também em virtude da concepção antiga da filosofia como modo de vida, natural que, para além das preocupações exclusivamente teóricas do contemplativo, despertasse igualmente a necessidade prática de um projeto de vida. E é precisamente para pôr em prática esse projeto que se compuseram as primeiras obras do filósofo, já desde os tempos de Cassicíaco até a curta temporada cenobítica em Tagasta, por volta dos anos 389-390, quando da composição do De magistro. O projeto, que se explicita em várias dessas obras, era percorrer um itinerário ascendente, desde os sentidos ao espírito, do corpo à mente, tendo como escopo a tão ansiada uita beata:

do De magistro porque todas essas partes, consideradas como palavras, são em si mesmas nomina. Assim, a palavra "conjunção", por exemplo, é também o "nome" que se dá às palavras et, sed, autem etc.

${ }^{50} \mathrm{Cf}$. Conf. 6,4,6: [...] spiritalia, de quibus cogitare nisi corporaliter nesciebam.

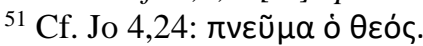


E contudo, se digo que existe uma certa vida feliz e que ela é sempiterna, para onde, tendo Deus por guia, isto é, a própria Verdade, por certos degraus acomodados ao nosso passo vacilante eu desejaria ser conduzido, receio parecer ridículo porque tenha começado a ingressar por essa enorme via por meio da consideração dos signos, não das próprias coisas que são significadas. ${ }^{52}$

No entanto, como resta claro pela leitura da passagem, o próprio Agostinho sente necessidade de justificar o estudo dos signos, que lhe parece constituir matéria insignificante em comparação com a felicidade eterna que aguarda a alma após esta vida. Com efeito, em contraste com os objetivos que se perseguem, os signos constituem meros instrumentos, de natureza indubitavelmente inferior, a despeito do que se pense hoje pela ótica exclusivista da linguagem. Estudam-se os signos, justifica o filósofo (Mag. 8,21), pelo mesmo motivo por que se estudam as artes liberales, como gramática, dialética e retórica, por exemplo, porque seu estudo é um passo propedêutico, contudo em que se não deve permanecer como se fosse o ponto de destino, mas ultrapassar em direção às coisas que, no caso dos signos, são por eles significadas. Portanto um exercício propedêutico, e mais que isso, igualmente depurador, que permite à alma elevarse desde os corpos à natureza incorpórea, na esteira da proposta pitagórico-platônica que fez escola no Ocidente: "Portanto perdoa-me" - exculpa-se Agostinho com o seu interlocutor no diálogo, que era também seu filho, o adolescente Adeodato - "se estou preludiando contigo não por diversão, mas para exercitar as forças e a acuidade da mente, por meio das quais possamos não apenas suportar, mas também amar o calor e a luz daquela região, onde está a vida feliz" ${ }^{\prime 53}$. Isso explica bastante bem a impossibilidade de se atribuir o mesmo valor absoluto à linguagem que hoje se faz. Com efeito, o que se quer propedêutico de algo, como restará mais claro ainda no De doctrina christiana, tem estatuto inferior ao daquilo a que prepara, uma vez que os fins são sempre melhores do que os meios: "Pois é necessário que tudo aquilo que é em virtude de algo seja de menor valor do que aquilo em virtude do que é." 54 Assim também se dá com os signos, que, sendo apenas os meios por que as coisas são significadas, são necessariamente inferiores a elas: "as coisas que são significadas devem ser consideradas de maior valor do que os signos." ${ }^{55}$ E de modo semelhante, assim como a própria fala é melhor do que as palavras $^{56}$, os fins que se perseguem por meio da fala, ensinar e recordar, devem ter peso maior

\footnotetext{
${ }^{52}$ Mag. 8,21: et tamen si dicam uitam esse quandam beatam eamdemque sempiternam, quo nos deo duce, id est, ipsa ueritate, gradibus quibusdam infirmo gressui nostro accomodatis perduci cupiam, uereor ne ridiculus uidear, qui non rerum ipsarum quae significantur, sed consideratione signorum tantam uiam ingredi coeperim.

${ }_{53}$ Mag. 8,21: Dabis igitur ueniam, si praeludo tecum non ludendi gratia sed excercendi uires et mentis aciem, quibus regionis illius, ubi beata uita est, calorem ac lucem non modo sustinere uerum etiam amare possimus.

${ }^{54}$ Mag. 9,25: Quidquid enim propter aliud est uilius sit necesse est quam id propter quod est.

${ }_{55}^{5}$ Mag. 9,25: res quae significantur pluris quam signa esse perpendas.

${ }^{56}$ Mag. 9,26: quanto uerba minoris habenda sint quam id propter quod utimur uerbis.
} 
do que o meio empregado para tais fins; o que não implica dizer que as palavras têm pouca ou nenhuma utilidade ${ }^{57}$. Com efeito, se elas não se aplicam para o conhecimento imediato das coisas, contudo servem para admoestar a procurá-las (Mag. 11,36) (ut quaeramus res) ${ }^{58}$, o que não é de modo nenhum algo desprezível.

\section{De doctrina christiana: o uso e o fruto da palavra}

As palavras que aguardam o cristão depois da morte, ao atingir o terceiro céu, de acordo com o relato de uma visão profética narrado por Paulo em sua segunda missiva aos coríntios, bastante ao contrário das próprias palavras de que o apóstolo se utilizou para escrevê-lo, serão palavras "inefáveis" (ineffabilia uerba ${ }^{59}$, as quais a ninguém aqui neste orbe é dado falar, mas que ali, acresce Agostinho, hão de ser ouvidas da boca do próprio Cristo, não dos homens ${ }^{60}$. Pois bem, se se trata de palavras inefáveis e de um céu para lá deste céu, presumivelmente além das contingências do espaço-tempo, quando certamente o espírito estará depurado do peso dos sentidos corpóreos e preparado para suportar as luzes e o calor da morada eterna, de modo nenhum poderiam ser proferidas pelas bocas humanas. Todavia isso se refere apenas ao ali da eternidade, não ao aqui do espaço e do tempo, onde ao homem, que é templo de Deus, consoante com o dito paulino ${ }^{61}$, não apenas é permitido propagar as palavras divinas, mas também ordenado. Pois Deus não enviou ao eunuco nenhum ser da estirpe celestial, diz Agostinho, referindose à passagem dos Atos dos apóstolos em que Filipe é levado à presença de um etíope para

\footnotetext{
${ }^{57}$ Mag. 14,46: sed de tota utilitate uerborum, quae, si bene consideretur, non parua est.

${ }^{58} \mathrm{O}$ conhecimento das línguas é belo e útil, reconhecerá Agostinho no De trinitate $(10,1,1-2)$, porque é por meio delas que as pessoas comunicam entre si aquilo que sentem, de modo que as relações (coetus) entre os homens não sejam ainda mais deterioradas pela solidão (solitudine), o que aconteceria se eles não pudessem "misturar" entre si seus pensamentos por meio da conversação (cogitationes suas non misceant... conloquendo). Como seria grandioso e bom poder compreender as línguas de toda gente $(10,1,2)$, exclama o rétor (omnes omnium gentium linguas intellegere), e também poder falá-las (ac loqui), ouvindo a nenhuma delas como estrangeira (nullamque ut alienigena audire) e por ninguém assim ser ouvido. Porém a ciência de todas as línguas é tarefa sem esperanças, daí restar à maioria o conhecimento de sua própria, cuja beleza toca o espírito que a conhece e que nela pensa, na reluzente glória do consórcio entre as almas, que se estabelece no ouvir e responder das vozes conhecidas, fazendo com que os pensamentos dos homens sejam conhecidos através da enunciação das vozes significantes (qua hominum inter se cogitata significantium uocum enuntiatione noscuntur).

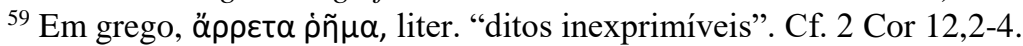

${ }^{60}$ De doctrina christiana (D.C.) - Prefácio §11: "Esperemos ser arrebatados 'até o terceiro céu, seja no corpo, seja fora do corpo', como diz o apóstolo, e ali ouvir 'as palavras inefáveis que não é dado ao homem falar', ou ali ver o senhor Jesus Cristo e dele próprio, antes que dos homens, ouvir o Evangelho" (et exspectemus rapi usque "in tertium caelum, siue in corpore, siue extra corpus", sicut dicit apostolus, et ibi audire "ineffabilia uerba quae non licet homini loqui", aut ibi uidere dominum Iesum Christum et ab illo potius quam ab hominibus audire euangelium).

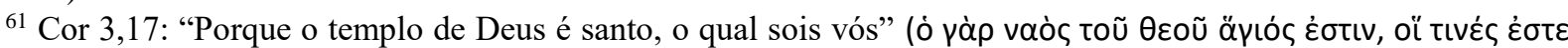

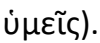


ensiná-lo a ler o livro do profeta Isaías (At 8,27-31), nem explicou o texto profético através da voz de um anjo, nem de nenhum modo "divino", por inspiração imediata em sua mente (diuinitus in mente); ao contrário, fê-lo pelo ministério humano, de modo que o mistério fosse revelado por meio das palavras de uma língua de comunicação (humanis uerbis et lingua) $(\$ 14)^{62}$. Portanto Deus preferiu o ministério humano, através das palavras e da língua dos homens, a fim de revelar (aperire) o que estava encoberto (tectum).

Por detrás da apologia da prédica humana levada a efeito nesta importante obra teórica da maturidade de Agostinho, há uma constatação do maior interesse para os propósitos desta investigação, a clara distinção que ele faz entre o divino e o humano. Se a Palavra que há de se fazer compreender no terceiro céu diretamente do próprio Cristo é inexprimível, só se pode dizer que o seja em linguagem humana, quer dizer, por meio das palavras audíveis de que se servem os homens neste mundo, palavras presas às cadeias do espaço-tempo, que só se permitem conhecer na íntegra em virtude da memória, que retém as sílabas pronunciadas numa sequência linear inescapável, umas inevitavelmente após as outras, de modo que se tenha a sensação, contudo enganosa, de que as palavras, como se todas monossilábicas, sejam integralmente pronunciadas num único sopro de ar, ou sejam pensadas de um só e instantâneo ato da mente, num único motus animi. Por outra, sendo a Palavra divina eterna, não poderia soar no tempo como a palavra humana, nem mesmo, in quantum eterna, no espírito dos homens, porque o espírito humano, embora seja imaterial, de modo nenhum é imutável como o uerbum dei, em que nenhum antes ou depois pode haver. Essa distinção, como se há de verificar mais tarde, é essencial para compreender, não pelo prisma contemporâneo, mas pela perspectiva do próprio autor, a relação que se permite depreender entre as duas palavras, a interior e a exterior, ou seja, entre o pensamento e a linguagem.

A utilidade dos signos reside exclusivamente em sua capacidade de significar alguma coisa $^{63}$, diz Agostinho, pois ninguém deles se utiliza senão para essa finalidade ${ }^{64}$. Porém se os signos, em que se constituem as palavras humanas, servem para alguma outra coisa que não eles, depreende-se que eles também sejam algo em si mesmos, pois o que não é alguma coisa não é nada ${ }^{65}$. E, com efeito, se a doutrina que o filósofo propugnou por advogar por toda uma vida, especialmente a partir do diálogo De libero arbitrio, iniciado já em 388, assentando as bases para a teodiceia cristã, insiste na bondade do Criador e na consequente bondade de todas

\footnotetext{
${ }^{62} \mathrm{Cf}$. In Ioh. euang. tract. CXXIV 1,6: quia per homines ministratae sunt scripturae.

${ }^{63}$ D.C. 1,2,2: alia signa quorum omnis usus in significando est, sicut sunt uerba.

${ }^{64}$ D.C. 1,2,2: nemo enim utitur uerbis nisi aliquid significandi gratia.

${ }^{65}$ D.C. 1,2,2: quam ob rem omne signum etiam res aliquid est, quod enim nulla res est, omnino nihil est.
} 
as criaturas ${ }^{66}$, sendo as palavras alguma coisa, sem dúvida constituem bens, seja em que degrau se as considere na ordenação da universalidade da criação divina. Todavia, se as palavras servem para algo ulterior, como ficou assente no De magistro $(9,25)$, onde se estabeleceu que aquilo que existe por causa de algo é inferior àquilo por causa de que existe, decorre necessariamente disso que os signos, em que elas se constituem, tenham estatuto ontológico inferior ao das coisas para as quais apontam como meios, que neste caso seriam os fins almejados. Daí a necessidade, não por acaso, de aprofundar nesta obra, quando se volta novamente para tratar dos signos, a célebre doutrina que já havia vislumbrado no De magistro, contudo sem dar-lhe maior destaque à época, doutrina da distinção entre os meios e os fins, agora expressa pelo contraste estabelecido entre os verbos depoentes uti, "usar", e frui, "fruir". De fato, se o signo serve para algo ulterior que não ele, ele é apenas útil, não devendo ser fruído em si mesmo, apenas usado como um instrumento para que se alcance fim ulterior. De onde o propalado papel secundário que Agostinho atribui à linguagem, visto que na eternidade beatífica ela será absolutamente prescindível - ao menos com a natureza que aqui tem e com a finalidade com que se utiliza neste mundo corpóreo. Contudo dizê-lo simplesmente, como se tem feito adrede, completamente destacado do contexto e do caráter geral de sua filosofia, e a partir de uma perspectiva que lhe é tão mais anacrônica quanto ádvena, não se pode dizer que seja algo além de deformar-lhe o pensamento.

Portanto as palavras devem ser apenas usadas, porque "usar" é relacionar-se com o que seja útil para obter o que se ama, se de fato se deva amá-lo ${ }^{67}$, ao passo que "fruir é aderir com amor a alguma coisa em virtude dela própria”, explica Agostinho ${ }^{68}$, o que só se aplica ao que é digno de fruição em si mesmo, que seja imutável e eterno, como o Fim que se deve amar e a que se deve almejar aderir, Deus, a Verdade imutável, pois é nela que reside a vida feliz (beata uita) do espírito:

[10] [...] deve-se fruir daquela Verdade que vive incomutavelmente, e nela a Trindade, Deus, autor e fundador da universalidade [da criação] [...] [22] portanto em todas estas coisas apenas aquelas é que devem ser fruídas, as quais são eternas e incomutáveis [...] Pois aquilo que deve ser amado em virtude de si mesmo, é nisso que consiste a vida feliz. ${ }^{69}$

\footnotetext{
${ }^{66}$ De libero arbitrio 3,13,36,126: "Portanto toda substância ou é Deus ou existe a partir de Deus, porque todo bem ou é Deus ou existe a partir de Deus" (omnis igitur substantia aut deus, aut ex deo, quia omne bonum aut deus, aut ex deo).

${ }^{67}$ D.C. 1,4,4: uti autem quod in usum uenerit ad id quod amas obtinendum referre, si tamen amandum.

${ }^{68}$ D.C. 1,4,4: frui est enim amore inhaerere alicui rei propter se ipsam.

${ }^{69}$ D.C.1,10,10: [...] illa ueritate perfruendum sit quae incommutabiliter uiuit, et in ea trinitas deus, auctor et conditor uniuersitatis [...] 1,22,20: in his igitur omnibus rebus illae tantum sunt quibus fruendum est, quas aeternas atque incommutabiles [...] quod enim propter se diligendum est, in eo constituitur beata uita.
} 
Do que se conclui, forçosamente, que "na vida desta mortalidade, peregrinando longe do Senhor, se quisermos retornar à pátria, onde podemos ser felizes, este mundo deve ser usado, não fruído", sentencia Agostinho ${ }^{70}$, visto que o esperado Reino de Deus não é daqui, como havia advertido o próprio Cristo ${ }^{71}$. E se é assim, as línguas são apenas meios para se chegar à Verdade, o Fim último e supremo que é Deus ${ }^{72}$. No entanto, dizer que a palavra é apenas um meio inferior ao fim a que serve não significa dizê-la inútil, como já foi lembrado. De fato, sendo um signo, definido no De dialectica como aquilo que, além de mostrar-se aos sentidos corpóreos, apresenta ao espírito alguma outra coisa que não ele ${ }^{73}$, com exceção dos signos naturais (naturalia signa), que significam destituídos de qualquer apetite de fazê-lo (D.C. 2,1,2), os signos dados (data signa) servem a propósito nada desprezível: publicar, quanto possível, os movimentos do próprio espírito (ad demonstrandos... motus animi) (D.C. 2,2,3), quer dizer, as coisas sentidas e inteligidas (sensa aut intellecta). Portanto o fim da linguagem, se se permite dizê-lo nestes termos, é a comunicação: "Não há uma única causa para que signifiquemos, isto é, para que demos signos, além de tirar de dentro e transferir para uma outra mente aquilo que traz na mente aquele que dá o signo"74. E assim como aquele que fala ou emite um signo não verbal, como um aceno com a cabeça, por exemplo, para comunicar aos outros sua vontade ${ }^{75}$, assim também por meio das Escrituras sagradas, exprimindo o pensamento daqueles que as escreveram, deu-se a conhecer a vontade de Deus aos homens, diz Agostinho ${ }^{76}$, o que confere às palavras, neste caso acima dos demais, valor substancial. Demais, se se trata da vontade de Deus, quer-se que seja imutável, una e eterna como ele, o que neste caso corroboraria a tese do conteúdo universal, como se poderia depreender das inúmeras traduções que se têm feito desde os primórdios, e ainda se fazem, dos textos sacros, segundo o argumento dos seus defensores.

\footnotetext{
${ }^{70}$ D.C. 1,4,4: in huius mortalitatis uita peregrinantes a domino, si redire in patriam uolumus, ubi beati esse possimus, utendum est hoc mundo, non fruendum.

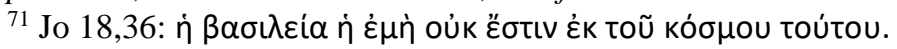

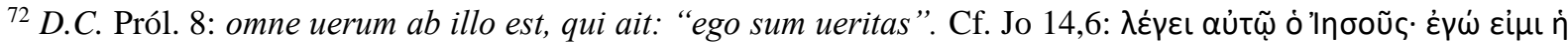

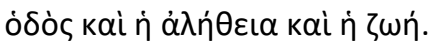

${ }^{73}$ Apesar de aprimorada, a definição mantém-se aqui praticamente inalterada, visto que o signo agora se diz "a coisa, além da aparência que penetra os sentidos, que faz com que alguma outra coisa, a partir de si, venha ao pensamento" (D.C. 2,1,1: signum est enim res praeter speciem quam ingerit sensibus aliud aliquid ex se faciens in cogitationem uenire). Portanto, além de tocar os sentidos, no caso das palavras o sentido da audição, o signo comunica à mente algo que não ele, porém a partir de si mesmo.

${ }^{74}$ D.C. 2,2,3: nec ulla causa est nobis significandi, id est, signi dandi, nisi ad depromendum et traiciendum in alterius animum id quod animo gerit qui signum dat.

75 D.C. 2,3,4: nam cum innuimus non damus signum nisi oculis eius quem uolumus per hoc signum uoluntatis nostrae participem facere.

${ }^{76}$ D.C. 2,5,6: "os que leem [a Escritura divina] não procuram nenhuma outra coisa além de descobrir os pensamentos e a vontade daqueles pelos quais ela foi escrita, e através delas a vontade de Deus, segundo a qual cremos tais homens terem falado" (quam [scripturam diuinam] legentes nihil aliud appetunt, quam cogitationes uoluntatemque illorum a quibus conscripta est inuenire, et per illas uoluntatem dei, secundum quam tales homines locutos credimus).
} 
Todavia nem toda palavra tem estatuto inferior, devendo ser usada apenas para fim ulterior, pois há uma palavra que deve ser fruída, sendo não apenas um fim em si mesma, mas o Fim supremo em que se espera repousar na eternidade sabática. E precisamente no intuito de pregar essa Palavra eterna, acima de tudo, mas não apenas contra as invectivas de ascendência gnóstica, como o maniqueísmo, justificando o mistério de sua Encarnação, que tanta disputa teológica motivou, é que Agostinho retoma uma tradição que remonta aos primeiros apologistas, como Justino de Roma (ou o Mártir) e Teófilo de Antioquia, conforme já foi mencionado a partir da indicação do importante trabalho de Claude Panaccio (2017, p. 68). A questão que se colocava, não apenas pelos gnósticos, mas também pelos filósofos gregos, não era nova, especialmente aos platônicos de todas as épocas e correntes, que se debateram exaustivamente para justificar a conversão da unidade à multiplicidade: de que modo, pois, uma Palavra eterna e imutável se faz mutável, adentrando as cadeias do tempo e do espaço, sem contudo sofrer nenhum detrimento em sua natureza? Para enfrentar essa nada fácil questão é que se aplicou o recurso da analogia, que de tanto ter sido explorado acabou por ser vetado pelo sínodo de Sírmio, pouco antes de Agostinho entrar em cena. Pois bem, assim como as palavras exteriores, lógoi prophorikoí, que antes de sair pela boca eram gestadas no interior como lógoi endiáthetoi, e que mesmo depois de proferidas não causavam detrimento algum nas palavras oriundas do coração (uerba cordis), que ali restavam íntegras, assim também a Palavra de Deus, não porque tenha saído de sua divina morada e habitado entre os homens, depois de ser proferida, quer dizer, depois de fazer-se carne na pessoa de Jesus, não por isso sofreu jamais qualquer detrimento em sua natureza, restando uma vez e sempre eterna e imutável em Deus. Percebe-se rapidamente a felicidade dessa analogia, responsável por sua insistente aplicação, como se verá nas passagens das obras que ainda resta apresentar. Todavia ela não deixou de ser usada aqui, como não surpreende, visto a linguagem, em certo sentido, ser o tema deste tratado:

\footnotetext{
Assim como, quando falamos, a fim de que o que trazemos no espírito deslize para dentro do espírito do ouvinte através de suas orelhas de carne, a palavra que gestamos no coração faz-se som e se chama "fala", contudo o nosso pensamento não se converte naquele mesmo som, mas, permanecendo íntegro em si mesmo, assume a forma da voz, pela qual se insinua nos ouvidos, sem qualquer perda [em virtude] de sua mutação, assim também a Palavra de Deus, não se tendo modificado, contudo se fez carne, a fim de que habitasse entre nós. ${ }^{77}$
}

\footnotetext{
${ }^{77}$ D.C. 1,13,12: Sicuti cum loquimur, ut id quod animo gerimus in audientis animum per aures carneas illabatur, fit sonus uerbum quod corde gestamus et "locutio" uocatur, nec tamen in eundem sonum cogitatio nostra conuertitur, sed apud se manens integra formam uocis, qua se insinuet auribus, sine aliqua labe suae mutationis assumit, ita uerbum dei non commutatum caro tamen factum est, ut habitaret in nobis.
} 
Do que se permite depreender da leitura desta passagem, destaca-se o seguinte. Primeiro, um dos objetivos da comunicação pela fala (locutio) é fazer "deslizar" no espírito do ouvinte aquilo que temos em nosso próprio espírito, o conteúdo de nossas mentes. Segundo, por alguma razão esse conteúdo mental, que se compreende como o pensamento, é dito também "palavra" (uerbum), seja por analogia com a "Palavra" de Deus que se fez carne segundo o célebre relato do evangelista João (Jo 1,1), tradução do grego lógos, seja porque guarde alguma semelhança com as palavras faladas. Porém o fato é que essa "palavra que gestamos no coração" (uerbum quod corde gestamus) é aqui sinônimo de cogitatio, "pensamento", o que permite supor, no mínimo, alguma relação entre a palavra falada pela boca e a palavra pensada no coração. Terceiro, o pensamento não se converte em voz, quer dizer, não sofre uma mutação em sua natureza, deixando de ser pensamento para fazer-se som (sonus), visto que, como é sabido, ninguém se vê privado de seu conteúdo mental após tê-lo publicado vocalmente. Ao contrário, mesmo depois de ter assumido uma forma sonora o pensamento mantém-se íntegro, tal como antes, na mente, como palavra do coração, o que serve bem ao propósito analógico, que o coteja ao Es-

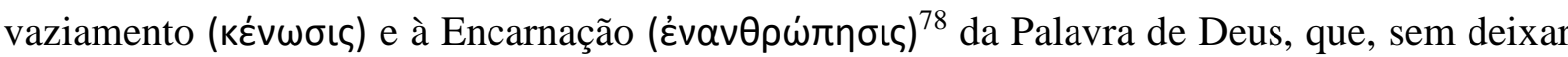
de ser Deus, fez-se carne para habitar entre os homens. Portanto, se por um lado faz-se uma clara distinção entre a natureza do que é gestado na mente e o que sai da boca, visto um ser inteligível e o outro corpóreo, contudo, a despeito da polissemia do termo uerbum, talvez não se diga "palavra" como simples decorrência das limitações impostas ao pensamento pelas categorias da língua latina, como talvez quisessem Wittgenstein ou Benveniste, para quem "o que se pode dizer é que delimita e organiza o que se pode pensar", sistema linguístico latino que, assim como o grego teria sobrecarregado o vocábulo $\lambda$ óyos de diferentes acepções, teria sido igualmente ineficaz para cunhar palavras distintas para realidades consideradas diametralmente opostas!

\section{Sermo 288: palavra do coração}

O quarto texto a ser analisado é uma passagem de homilia proferida em Cartago em $401^{79}$, portanto mais de uma década depois do De dialectica e do De magistro, contudo

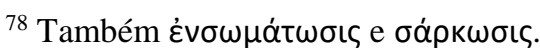

${ }^{79}$ PL 38, 1302-1308.
} 
contemporânea de algumas partes do De doctrina christiana, escrito ao longo de um intervalo de mais de duas décadas, entre 396 e 426/7 80 :

Procuremos o que exista entre a voz e a palavra! Procuremos, atentos. Não é uma coisa pequena, nem exige uma pequena atenção. O Senhor [nos] dará que nem eu me fatigue, ao explicar, nem vós, ao ouvir. Eis aqui duas coisas: a voz e a palavra! O que é a voz? O que é a palavra? O quê? Ouvi o que em vós próprios provais e a vós próprios, quando interrogados por vós mesmos, respondeis! Uma palavra, se não possua uma razão significante, não se diz "palavra". Porém a voz, ainda que de algum modo soe e produza estrépito, como o som de quem grita, não de quem fala, pode-se dizer “voz”, [mas] não se pode dizer "palavra". Não sei quem gemeu: é voz; choramingou: é voz! É sem dúvida um som informe, que traz ou carrega em si um estrépito aos ouvidos sem qualquer razão do intelecto. Porém a palavra, a não ser que signifique algo, a não ser que leve uma coisa aos ouvidos e leve outra coisa distinta até a mente, não se diz "palavra"...

Portanto a palavra, que, ao contrário de um simples som vocal, não é informe (informis sonus), possui uma razão significante (rationem significantem), que também pode ser compreendida como razão do intelecto (ratio intellectus), o que equivale a dizer que significa, isto é, que leva aos ouvidos de um ouvinte algo distinto do que leva mente adentro (menti inferat). Assim, o que se diz "palavra" (uerbum) sai pela boca de um falante em direção ao ouvido de algum ouvinte, mas também é levado para o interior de sua mente, onde de algum modo se faz razão do intelecto ou razão significante. Porém não é na boca do falante nem no ouvido do ouvinte que a palavra se torna significante. É no intelecto, através da razão, que ocorre o processo mental que interessa à filosofia da mente, que Panaccio chama de "problema da composição do pensamento", ou "princípio de composicionalidade" (2017, p. 41). Note-se, contudo, que uma homilia proferida em linguagem humilde (sermo humilis) não parece ser o veículo mais apropriado para tratar de um tema de tamanha complexidade, tampouco uma congregação de rudes berberes a audiência mais apta para compreendê-lo, ainda que se imagine uma Cartago povoada de intelectuais e clérigos oriundos de todas as partes do Império. Todavia Agostinho não se detém, desconsiderando, talvez, os limites intelectuais de seu auditório:

[...] Logo, assim como eu dizia: se grites, é voz; se digas "homem", é palavra; [também] se digas "gado"; se [digas] "Deus"; se [digas] "mundo"; ou alguma outra coisa.

\footnotetext{
${ }^{80}$ Os dois primeiros livros foram escritos por volta de 396, de par, talvez, com parte do terceiro, que teria sido concluído, juntamente com o quarto livro, por volta dos anos 426/7. As citações utilizadas neste trabalho, tendo sido extraídas dos dois primeiros livros, são anteriores ao proferimento do Sermo 288.

${ }^{81}$ Sermo 288 §3: Quaeramus quid intersit inter uocem et uerbum. attenti quaeramus. non parua res est, nec paruam intentionem desiderat. dabit dominus ut nec ego in explicando fatiger nec uos in audiendo. ecce duo quaedam: uox et uerbum. quid est uox? quid est uerbum? quid? audite quod in uobis ipsis approbetis et uobis ipsis a uobismetipsis interrogati respondeatis. uerbum, si non habeat rationem significantem, "uerbum" non dicitur. uox autem, etsi tantummodo sonet et irrationabiliter perstrepat, tamquam sonus clamantis, non loquentis, "uox", dici potest, "uerbum" dici non potest. nescio quis ingemuit, uox est; eiulauit, uox est. informis quidam sonus est, gestans uel inferens strepitum auribus sine aliqua ratione intellectus. uerbum autem, nisi aliquid significet, nisi aliud ad aures ferat aliud menti inferat, "uerbum" non dicitur...
} 
Pois eu disse estas vozes todas significantes, não inanes; não [vozes] que soam e nada ensinam. [...] Logo, se agora distinguistes entre a voz e a palavra, ouvi o que nos admira nestes dois, João [o Batista] e Cristo. A palavra vale mais, mesmo sem a voz; a voz é inane sem a palavra. Demos [agora] a razão disso e aquilo que propusemos, se pudermos, expliquemos!..82

A palavra é ainda uma voz significante (uox significans) que ensina algo (docens), ao contrário das vozes ditas "inanes", que apenas soam e nada ensinam (nihil docentes); e vale mais do que a voz, mesmo a palavra silenciosa (sine uoce). Portanto há uma palavra com voz e uma sem voz, uma palavra exterior, que soa, e uma palavra interior, silenciosa. Se sua natureza é distinta, porque usar o mesmo termo? Se a palavra sonora é articulada, por que a silenciosa não o seria? Assim como o lógos grego tem várias acepções, contudo todas correlatas, assim também o uerbum latino, que neste caso refere-se tanto ao conteúdo do pensamento quanto à palavra articulada. Se a voz é inane sem a palavra, isso significa o som sem significação, o som que não aponta para nada, nem nada ensina: mero ruído. Todavia a palavra, seja sonora, seja silenciosa, ensina e aponta para algo outro que não ela:

[...] Eis que tu quiseste dizer algo. Isto mesmo que tu queres dizer foi concebido no coração, está retido na memória, é preparado pela vontade, vive no intelecto. E isto mesmo que tu queres dizer não pertence a nenhuma língua. A própria coisa que tu queres dizer, que foi concebida no coração, não pertence a nenhuma língua, nem grega, nem latina, nem púnica, nem hebraica, nem de nenhum povo. É apenas uma coisa concebida no coração, preparada para [daí] proceder... ${ }^{83}$

$\mathrm{Na}$ atividade mental, por conseguinte, há os seguintes passos: (1) querer dizer algo, que se supõe seja um movimento nascido da vontade (uoluntate), quando não do próprio coração, pois (2) o que se quer dizer é concebido ali, no próprio coração (corde conceptum), ou seja, na mente ou espírito ${ }^{84}$; (3) o que se quer dizer é retido na memória; (4) preparado pela vontade (5)

\footnotetext{
${ }^{82}$ Sermo 288 §3: [...] sicut ergo dicebam: si clames, uox est; si dicas "homo", uerbum est; si dicas "pecus"; si [dicas] "deus"; si [dicas] "mundus", uel aliquid aliud. has enim omnes uoces significantes dixi, non inanes; non sonantes et nihil docentes. si ergo iam distinxistis inter uocem et uerbum, audite quod miremini in his duobus, Ioanne et Christo. uerbum ualet plurimum et sine uoce; uox inanis est sine uerbo. reddamus rationem et quod proposuimus, si possumus, explicemus...

${ }^{83}$ Sermo 288 §3: [...] ecce uoluisti aliquid dicere. hoc ipsum quod uis dicere iam corde conceptum est, tenetur memoria, paratur uoluntate, uiuit intellectu. et hoc ipsum quod uis dicere non est alicuius linguae. res ipsa, quam uis dicere, quae corde concepta est, non est alicuius linguae, nec Graecae, nec Latinae, nec Punicae, nec Hebraeae, nec cuiusquam gentis. res est tantum corde concepta, parata procedere...

${ }^{84}$ No diálogo De libero arbitrio (388-395) Agostinho tampouco faz distinção clara entre os termos mens, animus e spiritus, considerados indiscriminadamente como o princípio inteligente $(1,8,18,61)$ : "seja o que for isto pelo que o homem é colocado à frente das reses, denomine-se 'mente' ou 'espírito', ou mais corretamente os dois termos..." (hoc quidquid est, quo pecoribus homo praeponitus, siue mens, siue spiritus, siue utrumque rectius...); $(1,8,18,65)$ "Logo essa razão, ou mente, ou espírito, quando rege os movimentos irracionais da alma..." (ratio ista ergo, uel mens, uel spiritus, cum inrationales animi motus regit...). Todavia, se acaso sejam distintos, mente e razão, pondera o filósofo, resta claro que esta última é instrumento da primeira, não o contrário $(1,9,19,68)$ : "Mas se uma coisa é a razão, outra a mente, torna-se certamente evidente que nada, exceto a mente, pode usar da razão" (sed si aliud ratio, aliud mens, constat certe nonnisi mentem uti posse ratione). Cf. L.A. 1,7,16,56; 58; 8,18,61.
} 
e vive no intelecto (intellectu). Nada clara a distinção entre coração e intelecto, nem a exata função e a localização da vontade nesse movimento. Porém, se se quer dizer algo, esse algo, que não pertence a nenhuma língua (non est alicuius linguae), que foi concebido no coração, que é preparado pela vontade e que vive no intelecto precisa ser de algum modo verbalizado, do contrário daí não pode proceder na forma de palavra, ou discurso:

[...] Logo, como disse, é uma certa coisa, uma certa sentença, uma razão concebida no coração, preparada para [daí] proceder, a fim de que seja no ouvinte insinuada. Assim, pois, do mesmo modo como lhe é conhecida, em cujo coração está, é agora uma palavra conhecida ao que vai dizê-la, [mas] ainda não ao que irá ouvi-la. Logo eis uma palavra agora formada, agora íntegra, que permanece no coração. Ela quer proceder, a fim de que seja dita ao ouvinte. Volta-se aquele que concebe a palavra para dizê-la, e que possui a palavra conhecida para si em seu coração; volta-se para aquele ao qual há de dizê-la... ${ }^{85}$

Que é essa palavra? Diz Agostinho que é uma “certa sentença” (sententia quaedam), uma "razão" (ratio) concebida no coração, preparada pela vontade para daí proceder, de modo que seja insinuada, isto é, introduzida na mente do falante através de seu ouvido. Essa sententia, seja qual for sua natureza, contudo não apenas é conhecida (nota) daquele que a possui no coração, ou seja, é possuída com algum discernimento, mas também possui uma forma, algum tipo de determinação, além de ser íntegra (integrum), quer dizer, não em aspecto algum defeituosa

[...] Falarei em nome de Cristo ao ouvidos instruídos na Igreja, e ouso ainda insinuar alguma coisa agora que seja mais sutil aos que não são incultos. Preste pois atenção a vossa caridade! Vede a palavra concebida no coração, ela procura proceder [daí], a fim de que seja dita; ela tende na direção daquele ao qual se diz! Encontra um homem grego? Ela procura uma voz grega pela qual proceda até o grego. Encontra um homem latino? Ela procura uma voz latina, pela qual proceda até o latino. Encontra um púnico? Ela procura uma voz púnica pela qual proceda até o púnico. Remove a diversidade dos ouvintes e aquela palavra, que foi concebida no coração, nem é grega, nem é latina, nem é púnica, nem de língua qualquer! Ela busca uma voz que procede tal qual ao ouvinte assiste... ${ }^{86}$

\footnotetext{
${ }^{85}$ Sermo 288 §3: [...] ergo, ut dixi, res est quaedam, sententia quaedam, ratio corde concepta, parata procedere, ut insinuetur audienti. sic igitur quomodo nota est ei, in cuius corde est, uerbum est iam notum dicturo nondum audituro. ecce ergo uerbum iam formatum, iam integrum, manet in corde. quaerit procedere, ut dicatur audienti. attendit ille qui concepit uerbum quod dicat, et notum habet uerbum sibi in corde suo, attendit cui dicturus est... ${ }^{86}$ Sermo 288 §3: [...] loquar in nomine Christi auribus eruditis in ecclesia, et audeo etiam aliquid iam quod sit subtilius insinuare non rudibus. intendat ergo caritas uestra. uidete uerbum corde conceptum, quaerit procedere, ut dicatur; attendit cui dicatur. inuenit Graecum? Graecam uocem quaerit, qua procedat ad Graecum. inuenit Latinum? Latinam uocem quaerit, qua procedat ad Latinum. inuenit Punicum? Punicam uocem quaerit, qua procedat ad Punicum. remoue diuersitatem auditorum et uerbum illud, quod corde conceptum est, nec Graecum est, nec Latinum, nec Punicum, nec cuiusquam linguae. talem uocem quaerit procedendi, qualis assistit auditor...
} 
Essa palavra do coração, se encontra um homem romano, procura uma voz latina para que proceda até ele. Note-se que essa procura pelo idioma é feita na mente daquele que possui a palavra do coração, não em sua boca. Ela procura uma voz latina, ou grega, que encontrará, por certo, desde que a tenha ali disponível, quer dizer, na memória, de onde a retirará. Essa palavra grega, ou latina, ou púnica, contudo é sempre palavra, pois é com ela que ele irá se fazer compreender pelo grego ou latino ou púnico, do contrário não seria compreendido. Essa operação mental, portanto, é de natureza linguística, visto que não há voz que não seja de alguma língua, o que não parece ser mais que uma obviedade. O fato é que tanto a palavra do coração, como a voz, seja grega, seja latina, estão na mente, ou armazenadas na memória, na qualidade de sententia ou ratio conhecida, formada e íntegra, ou na qualidade de possuidora de razão significante, razão do intelecto, que leva aos ouvidos algo distinto do que leva à mente, seja uma voz significante no primeiro caso, seja uma palavra silenciosa no segundo.

[...] E assim, irmãos, a fim de que vos seja proposto algo de modo que compreendais, eu concebi no [meu] coração dizer "Deus". Isto que concebi no coração é algo grande. Pois estas duas sílabas ${ }^{87}$ não são Deus; e esta voz breve não é Deus. Quero dizer "Deus"; volto-me para aquele ao qual o direi. É latino? Digo "Deus". É grego? Digo "Theós". Ao latino digo "Deus"; ao grego digo "Theós". Entre "Deus" e "Theós" o som é distinto: umas letras estão aqui, outras estão ali. Porém no meu coração, naquilo que quero dizer, naquilo que cogito, não há nenhuma diversidade de letras, nenhum som variado de sílabas. Isto é o que é..... ${ }^{88}$

Deus, considerado em si mesmo como o Criador de todas as naturezas, não é o signo linguístico composto em latim de duas sílabas, deus, nem a voz, considerada em si mesma, sem seu significado, ou a voz de cada uma das sílabas, caso Agostinho tenha desejado fazer essa distinção. O que pretende dizer, pois, é que há um único referente, Deus (em vernáculo), cuja expressão em línguas varia, como os exemplos aduzidos por ele do grego e do latim. Deus, contudo, é o mesmo, independente da língua que o invoque. As duas importantes questões que se põem a partir disso são as seguintes. Primeiro, em que pensa alguém quando pensa em Deus, se não pensa em nenhuma língua, nem grega, nem latina? Como o invoca? A segunda, contudo, vai na direção inversa: se o deus latino é diferente do $\theta \varepsilon o ́ s$ grego, segundo o que se depreende de concepção contemporânea acerca da linguagem, que advoga a tese de que só posso pensar o

\footnotetext{
${ }^{87}$ A palavra latina deus constituía-se de duas sílabas, de-us, não de uma, como em vernáculo.

${ }^{88}$ Sermo 288 §3:[...] modo, fratres, ut aliquid propositum sit quod intellegatis, concepi corde ut dicam "deus". hoc quod concepi corde magnum aliquid est. non enim duae syllabae sunt deus; non enim uox ista breuis est deus. "deum" uolo dicere, intendo cui dicam. Latinus est? "deum" dico. Graecus est? Ocóv dico. Latino dico "deum"; Graeco dico $\theta$ cóv. inter "deum" et $\theta$ cóv distat sonus: litterae aliae sunt hic, aliae sunt ibi. in corde autem meo, in eo quod uolo dicere, in eo quod cogito, nulla est diuersitas litterarum, nullus sonus uarius syllabarum. hoc est quod est...
} 
que posso dizer, tem-se que latinos e gregos invoquem deuses distintos, já que a referência, neste caso, é função exclusiva da linguagem. Assim, não sendo possível pensar em Deus, nem deprecá-lo, fora da linguagem, como diria o crente: "Deus, tende piedade de mim!", sem dizêlo em alguma língua? Por outra, não parece correto dizer que um romano que dissesse: Domine,

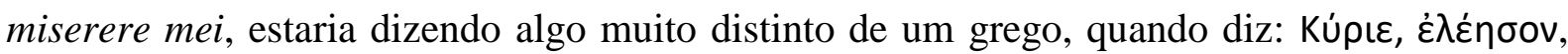
nem que estivesse invocando um deus diferente. Essa questão será retomada na sequência, depois da análise do restante da homilia:

[...] Para que se o enunciasse ao latino, uma voz foi empregada; ao grego, outra. Se quisesse enunciar a um púnico, uma outra voz empregaria; se a um hebreu, uma outra; se a um egípcio, outra; se a um hindu, outra. Quão numerosas vozes, através da mudança de pessoas, faria a palavra do coração, sem qualquer mudança de si ou variação? Procede até o latino pela voz latina; até o grego, pela grega; até o hebreu, pela hebraica. Ela vem até o que ouve e não se afasta do que fala. E por acaso aquilo que, quando o digo o transformo em outra coisa, eu o perco? Aquele som mediador empregado propagou alguma coisa para ti, [que] de mim não emigrou... ${ }^{89}$

A palavra do coração (uerbum cordis) não muda quando se mudam as "vozes", que neste caso refere-se às línguas, ou ao som que elas emitem, visto que ela "não pertence a nenhuma língua" (non est alicuius linguae), como dito no início. Porém note-se que ela procede do coração já na forma adequada, isto é, na voz que assiste ao ouvinte, na voz que lhe mais convenha. Essa operação, de traduzir o que se pensa em linguagem, é uma operação do próprio "coração", o que equivale a dizer que o espírito recorre ao conteúdo armazenado em si, que para Agostinho transcende a linguagem, a fim de traduzi-lo em linguagem, a partir do acervo linguístico que possua em si. Nenhuma dúvida que para ele havia uma realidade ulterior, muito além da contingência da linguagem humana, que neste caso é Deus, um referente, se se pode dizê-lo, irreferível. O que se têm no coração, ao ser dito, é transformado em outra coisa, pois "deus" não é apenas uma palavra de duas sílabas, nem um som qualquer sem significação para um ouvinte que não compreenda o latim, mas o Ser supremo, inconcebível, porque eterno e infinito; numa palavra, algo que é em si mesmo. Querer que Agostinho imaginasse que sua língua, o latim, fosse responsável por moldar a divindade a que dedicava sua vida e seus talentos, é um despropósito; querer que ele achasse que havia uma divindade distinta para cada língua falada por cada povo, o seria do mesmo modo. Havia para ele uma Substância absoluta, independente, que, a despeito da linguagem em que fosse referida, não deixaria de existir, do contrário seria

\footnotetext{
${ }^{89}$ Sermo 288 §3: [...] ut enuntiaretur Latino, alia uox adhibita est; ut Graeco, alia. si Punico enuntiare uellem, aliam adhiberem; si Hebraeo, aliam; si Aegyptio, aliam; si Indo, aliam. quam multas uoces faceret personarum mutatione uerbum cordis, sine ulla sui mutatione uel uarietate? pergit ad Latinum uoce Latina; ad Graecum Graeca; ad Hebraeum Hebraea. ad audientem peruenit, nec a loquente discedit. numquid enim quod dicendo in alio facio, ego amitto? sonus ille adhibitus medius in te aliquid propagauit, a me non emigrauit...
} 
imaginá-lo apenas uma palavra ou conceito na mente dos falantes, que, se deixassem de existir de súbito, deixaria de ser com eles no mesmo instante. Isso, embora seja a tese corrente, era inaceitável para Agostinho.

[...] Eu cogitava então "Deus"; tu ainda não havias ouvido a minha voz. Depois que esta foi enviada, começaste também tu a possuir o que eu cogitava. Mas eu não perdi o que possuía. Logo em mim, como na dobradiça do meu coração, como no segredo de minha mente, a palavra precedeu a minha voz. Ainda não soou a voz em minha boca e a palavra já está contida no meu coração. No entanto, para que saia para ti aquilo que concebi no coração, ele procura o ministério da voz..$^{90}$

A palavra do coração, que é sententia e ratio, precede a voz, o som das línguas. Essa palavra necessita do ministério da voz, assim como Deus fez uso do ministério da carne para chegar aos ouvidos e corações humanos. Porém, sendo anterior a toda linguagem, como pode ser sententia e ratio? Ou seria anterior a toda língua (uox), mas não à linguagem, entendida como a capacidade de produzir sons articulados e ordenados num sistema coeso? Apesar de a questão ter sido considerada decidida pelos linguistas e filósofos da linguagem, a partir da assertiva do próprio autor de que a palavra do coração não é de língua nenhuma, percebe-se uma lacuna evidente que clama por análise mais acurada. Imaginar Agostinho pensando a partir das categorias com que o fez Wittgenstein parece deformá-lo tanto quanto a leitura que o filósofo austríaco fez de seu pensamento. O que se deve perceber nesta passagem, de preferência, para além dos objetivos pastorais do recém-consagrado bispo em face de seu rebanho, sentado em sua cadeira curul diante da nave de alguma basílica em Cartago, sem dúvida repleta de crentes de toda sorte e nível de compreensão, é o fato, tanto mais simples quanto assombroso, de que o exemplo escolhido pelo rétor refere-se a Deus, detalhe que por si só excluiria o excerto do rol das passagens paradigmáticas passíveis de análise, ao menos a partir do prisma exclusivo da linguagem humana. Ora, não é a primeira nem será a última vez que Agostinho recorrerá a esse expediente, por motivos que transcendem a exclusiva preocupação com a linguagem. De volta ao De doctrina christiana, é possível destacar uma passagem das mais ilustrativas a esse respeito:

Dissemos alguma coisa e emitimos algum som digno de Deus? De modo nenhum. Na verdade, sinto não ter desejado nada além de dizer. Porém, se disse, não é isto o que quis dizer. De onde é que eu sei isto, senão porque Deus é inefável? No entanto, aquilo que foi dito por mim, se fosse inefável, não teria sido dito. E por conta disto nem sequer se deve dizer que Deus é inefável, porque também isto, quando se diz, algo se

\footnotetext{
${ }^{90}$ Sermo 288 §3: [...] “deum” iam ego cogitabam; tu nondum audieras uocem meam. hac audita, coepisti et tu habere quod cogitabam. sed ego non perdidi quod habebam. ergo in me, tamquam in cardine cordis mei, tamquam in secretario mentis meae, praecessit uerbum uocem meam. nondum sonuit uox in ore meo, et inest iam uerbum cordi meo. ut autem exeat ad te quod corde concepi, ministerium uocis inquirit.
} 
diz. E dá-se aqui não sei que conflito de palavras, porque se é inefável aquilo que não se pode dizer, não é inefável aquilo que se pode dizer inefável. Deve-se procurar evitar um tal conflito de palavras mais no silêncio das palavras que procurar pacificá-lo pela voz. E contudo Deus, embora dele nada se possa dizer de modo digno, aquiesceu à reverência da voz humana e quis que nos regozijássemos em seu louvor por meio de nossas palavras. E é daí o fato de também se dizer "Deus". Com efeito, ele mesmo não se faz conhecer verdadeiramente no ruído dessas duas sílabas. Todavia, quando esse som lhes toca os ouvidos, leva os falantes todos da língua latina a pensar numa natureza suprema e imortal. ${ }^{91}$

O som "deus", considerado in quantum palavra (uerbum), define-se como sendo uma voz articulada com algum significado ${ }^{92}$. Porém qual é o seu significado? Remete-se de fato a uma coisa (res) significável (significabilis)? Em certo sentido, sim, pois aponta para algo que não ele, o qual, se não existisse, nada seria ${ }^{93}$. Mas para o que aponta é impossível dizer, pois tratase de um referente inefável, incompreensível, infinito. Que faz então o signo latino deus? Não é verdadeiramente no estrépito dessas duas sílabas que o próprio Deus é conhecido, visto que, como dito no De magistro, as palavras permitem que o ouvinte rememore o que já conhecia, trazendo sua imagem desde a memória até a mente. Contudo quem é que pode dizer que jamais viu a Deus, que possa rememorá-lo por estar retido em sua memória, como um conteúdo armazenado? Seguramente ninguém, como afirmara peremptoriamente o evangelista João ${ }^{94}$. Então é preciso que a palavra deus faça algo distinto. Quando o som dessas duas sílabas toca os ouvidos de um conhecedor da língua latina, diz Agostinho, o ouvinte é levado a pensar numa natureza a mais excelente de todas e imortal. Então o signo, neste caso, não evoca uma imagem mental, nem recupera algo gravado na memória a partir de experiência sensorial, mas suscita pensamentos, ou melhor, faz com que se ponha a pensar (cogitandam) acerca de uma certa substância que seja a mais excelente de todas e imortal. E como faz isso, senão pelas faculdades da inteligência (intellectus), visto que a natureza que é a mais excelente (excellentissimam) sem dúvida o é apenas em comparação com outras naturezas, e o que é imortal não pode morrer. Vê-se que se trata de conceitos abstratos complexos, como "substância", "excelência" e "imortalidade", os quais, por sua vez, implicam outros conceitos, como "mortalidade", "incapacidade

\footnotetext{
${ }^{91}$ D.C. 1,6,6: Diximusne aliquid et sonuimus aliquid dignum deo? imo uero nihil me aliud quam dicere uoluisse sentio. si autem dixi, non est hoc quod dicere uolui. hoc unde scio, nisi quia deus innefabilis est? quod autem a me dictum est, si ineffabile esset, dictum non esset. ac per hoc ne ineffabilis quidem dicendus est deus, quia et hoc cum dicitur, aliquid dicitur. et fit nescio quae pugna uerborum, quoniam si illud est ineffabile quod dici non potest, non est ineffabile quod uel ineffabile dici potest. quae pugna uerborum silentio cauenda potius quam uoce pacanda est. et tamen deus, cum de illo nihil digne dici possit, admisit humanae uocis obsequium, et uerbis nostris in laude sua gaudere nos uoluit. nam inde est et quod dicitur "deus". non enim re uera in strepitu istarum duarum syllabarum ipse cognoscitur. sed tamen omnes Latinae linguae socios, cum aures eorum sonus iste tetigerit, mouet ad cogitandam excellentissimam quamdam immortalemque naturam.

${ }^{92}$ Cf. Mag. $4,9$.

${ }^{93}$ Cf. D.C. $1,2,2$.

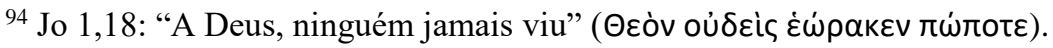


de morrer", "comparação", entre tais. Ora, se o que é mortal é o que pode morrer, depreendese que o que seja imortal não morra nunca, o que se percebe apenas através de uma operação mental de natureza silogística, como se sabe. E essas operações mentais, como Agostinho bem o disse, foram suscitadas por uma palavra, um signo, uma voz articulada em duas sílabas latinas, porém que significa não uma coisa, nem uma imagem, nem uma sensação, mas toda uma complexa gama de raciocínios interconectados, dependentes uns dos outros, cujo vínculo se estabelece e sustém apenas e exclusivamente pelas faculdades mentais. Mas neste caso a palavra nem ensina, nem faz lembrar - os dois objetivos da linguagem expressos no De magistro - o que é Deus, muito menos o mostra, mas, ao contrário, leva à cogitação, ao pensamento, tão mais complexo quanto abstrato, o que não se faz sem o subsídio de uma língua, apenas por imagens, nem mesmo sem o subsídio de estruturas sintáticas e lógicas elaboradas, que permitam deduções, como em: o que é imortal não morre; ou comparações, como em: quem é mais excelente do que todos está posicionado acima dos demais segundo alguma qualidade; exclusões, como em: quem é uma substância não é acidente, e assim sucessivamente.

Vê-se, por conseguinte, que a palavra "Deus" não serve de exemplo, se se a destaque dos escritos de Agostinho, prescindindo de seu contexto filosófico e histórico. Demais, imaginar que ele ignorasse os movimentos da inteligência suscitados pelo signo "Deus" seria tão deformador de seu pensamento quanto imaginar que eles se fizessem de algum outro modo que não o discursivo, quer dizer, segundo as categorias lógico-linguísticas com que eles se processam na mente humana, como resta ainda mais claro na sequência da passagem, ainda no De doctrina christiana, quando procura tornar claras as operações mentais daquele que se põe a pensar em Deus, acredite nele ou não:

\begin{abstract}
De fato, quando o único Deus dos deuses é pensado, mesmo por estes que presumem haver outros deuses, e os chamam e os cultuam, seja no céu, seja na terra, ele é pensado de tal modo que o pensamento se esforce por atingir algo melhor e mais sublime do que nada exista ${ }^{95}$. E porque são motivados por bens diversos, em parte pelos que pertencem ao sentido do corpo, em parte pelos que pertencem à inteligência do espírito, os que se devotam aos sentidos do corpo, ou o próprio céu, ou o que veem de mais fulgurante no céu, ou o próprio mundo, isso é o que julgam ser o deus dos deuses; ou então, se se esforçam por ir além do mundo, imaginam algo de luminoso, e seja infinito, seja na forma que lhes pareça a melhor, isso é o que estabelecem por meio de uma vã presunção, ou então imaginam uma figura de corpo humano, se é o que colocam à frente das demais coisas. [...] Porém aqueles que através da inteligência empreendem ver o que é Deus, esses o colocam à frente de todas as naturezas visíveis e corpóreas, também das inteligíveis e espirituais, todas elas mutáveis. Contudo todos eles disputam contenciosamente em favor da excelência de Deus, e não se pode
\end{abstract}

\footnotetext{
${ }^{95} \mathrm{O}$ pensamento se esforça por atingir algo acima do quê nada mais possa existir, visto ter-se chegado ao limite do limite do bem que se possa imaginar, uma excelência além da qual não é possível conceber.
} 
encontrar alguém que creia que exista alguma coisa melhor do que Deus. E assim todos consentem que Deus seja isto, que põem à frente de todas as demais coisas. ${ }^{96}$

Portanto quem pensa em Deus desse modo, crendo-o ser algo acima do quê nada mais exista, nem melhor ${ }^{97}$, fazendo-o a partir do signo "deus", não pensa numa imagem mental armazenada na memória, proveniente da experiência dos sentidos, nem volta sua mente para a coisa em si, que desconhece, mas suscita um mecanismo dos mais complexos, que movimenta não apenas as faculdades raciocinativas da mente, que se dizem intellectus ou ratio, mas também palavras, conceitos, e tudo o mais que está armazenado na memória, para que, a partir de conexões as mais elaboradas, a maior parte das quais estruturadas sintática e logicamente por meio inequívoco da linguagem, consiga efetuar tais conjecturas. Ao dizer que quem pensa em Deus pensa numa natureza melhor do que a qual nada mais exista, diz que pensa em algo cuja complexidade não se pode retratar em imagens, apenas pelos recursos os mais abstratamente complexos da mente racional, através de conexões e relações imponderáveis entre a ideia de uma divindade e uma gama imensurável de proposições, naquilo que Burnyeat (1987, p. 21) denominou com propriedade "conectibilidade explicativa", porque se trata inequivocamente da "apreensão sinótica" de toda uma área do saber, que não se logra realizar senão por meio de operações, sintáticas e lógicas, que não se compreendem isoladas de seu contexto, seja ele cultural, seja filosófico, seja meramente linguístico.

No entanto, se isso pode ser dito do proferimento do signo latino deus, o mesmo não se aplica com semelhante facilidade aos demais signos de caráter vulgar. Portanto resta aprofundar a investigação acerca da natureza dessa palavra-pensamento, que é sententia e que é ratio, a qual é concebida no coração, e que, como foi dito no início da passagem, é preparada pela vontade, retida na memória e vive no intelecto, pois se ela de fato não pertence a língua nenhuma, como a leitura obriga a interpretar, torna-se muitíssimo difícil não apenas relacioná-la à linguagem, mas também compreender como se converte naquela palavra que depois será proferida pela boca, cujo nome, "palavra", neste caso, pouco lhe parece apropriado.

\footnotetext{
${ }^{96}$ D.C. 1,7,7: Nam cum ille unus cogitatur deorum deus, ab his etiam qui alios et suspicantur et uocant et colunt deos, siue in caelo, siue in terra, ita cogitatur, ut aliquid quo nihil sit melius atque sublimius illa cogitatio conetur attingere. sane quoniam diuersis mouentur bonis, partim eis quae ad corporis sensum, partim eis quae ad animi intellegentiam pertinent, illi qui dediti sunt corporis sensibus, aut ipsum caelum, aut quod in caelo fulgentissimum uident, aut ipsum mundum, deum deorum esse arbitrantur; aut si extra mundum ire contendunt, aliquid lucidum imaginantur idque uel infinitum uel ea forma quae optima uidetur inani suspicione constituunt, aut humani corporis figuram cogitant, si eam ceteris anteponunt. [...] illi autem, qui per intellegentiam pergunt uidere quod deus est, omnibus eum naturis uisibilibus et corporalibus, intellegibilibus uero et spiritalibus omnibus mutabilibus praeferunt. omnes tamen certatim pro excellentia dei dimicant, nec quisquam inueniri potest, qui hoc deum credat esse, quo est aliquid melius. itaque omnes hoc deum esse consentiunt, quod ceteris rebus omnibus anteponunt.

${ }^{97} \mathrm{Cf}$. De libero arbitrio 2,6,14,54: quo nullus est superior.
} 


\section{In Iohannis euangelium tractatus CXXIV: palavra que é Deus}

Nos primeiro e décimo quarto tratados dos 124 que Agostinho escreveu e proferiu acerca do Evangelho de João, escritos por volta dos anos 406/798, ele retoma o mesmo tema apresentado no Sermo 288 e na passagem do De doctrina christiana supracitada, com algumas nuanças que merecem destaque. Note-se, antes de mais, que o rétor inicia a obra com uma importante ressalva que respeita não apenas ao que irá tratar, mas ao que o próprio evangelista pôde realizar em sua narrativa: “Ouso dizer, meus irmãos, que talvez nem o próprio João tenha dito [o que disse] do modo como é, mas que também ele [o disse] como pôde, porque disse a respeito de Deus, [na qualidade de] homem, e ainda que tenha sido inspirado por Deus, contudo [era] um homem"99. Com efeito, sendo apenas um homem, que falava a língua dos homens, João estava adentrando terreno desconhecido, muito acima das possibilidades, não apenas do pensamento, mas sobretudo da linguagem humana. Daí a ressalva do autor, assim como a que aqui se faz, de que da Palavra eterna se deve aproximar com cautela, visto que se encontra numa região supraceleste, para lançar mão da célebre expressão platônica ${ }^{100}$, não podendo ser confundida com as palavras, quer silentes, quer vocais, com que se pensam e falam as coisas deste mundo, porque a Palavra, que transcende toda a criação, é o próprio Deus:

De fato, visto que o salmo enumerasse todas estas coisas, assim concluiu: "Ele disse e foram feitas, ele mandou e foram criadas" [S1 148,5]. Se disse e elas foram feitas, é pela Palavra que foram feitas; porém, se foram feitas pela Palavra, não pôde o coração de João chegar até aquilo, que diz: "No princípio era a Palavra e a Palavra era junto a Deus e Deus era a Palavra", a não ser que transcendesse todas as coisas que foram feitas através da Palavra. ${ }^{101}$

Se é notório que João nos tenha brindado com palavras humanas, obtempera Agostinho, contudo não é menos notória a Fonte de onde ele próprio hauriu o que haveria de oferecer-nos a beber: "e do coração do Senhor ele bebeu aquilo com que nos brindaria, mas brindou com palavras ${ }^{102}$. Porém deves compreender com isso de onde é que havia bebido aquele que brindaria, de modo de que eleves os olhos até os montes, de onde virá o teu auxílio, para que a partir

\footnotetext{
${ }^{98}$ PL 35, CCSL 36. A obra foi concluída por volta de 419/20.

${ }^{99}$ In Ioh. 1,1: Audeo dicere, fratres mei, forsitan nec ipse Iohannes dixit ut est, sed et ipse ut potuit, quia de deo homo dixit, et quidem inspiratus a deo, sed tamen homo.

${ }^{100}$ Cf. Fedro 247c: úrep oupávios tóros.

${ }^{101}$ In Ioh. 1,5: nam cum enumeraret haec omnia psalmus, conclusit sic: "Ipse dixit et facta sunt, ipse mandauit et creata sunt". si dixit et facta sunt, per uerbum facta sunt; si autem per uerbum facta sunt, non potuit Iohannis cor peruenire ad id quod ait: "In principio erat uerbum et uerbum erat apud deum et deus era uerbum", nisi transcendisset omnia quae sunt facta per uerbum.

${ }^{102}$ Liter. "deu de beber palavras".
} 
daí receba, ao modo de um cálice, a palavra que te foi brindada" ${ }^{103}$.Oferecida como brinde à saúde das almas, a palavra tem origem no coração do Senhor (de pectore domini): João bebeu do coração, porém brindou palavras! Do coração de Deus ao coração dos homens, nesse percurso, do inteligível ao sensível, a Palavra de Deus se fez carne e habitou entre os homens, isto é, fez-se Palavra audível. Mas que não se pense que o que sai da boca e toca os ouvidos seja mais presente aos que falam e ouvem, pois é o exato oposto o que se dá: "Mas talvez me direis isto, que eu estou para vós mais presente do que Deus. Longe disso! Ele é muito mais presente, pois eu apareço aos vossos olhos, ele preside às vossas consciências. A mim, os ouvidos; a ele, o coração, de modo que preenchais um e outro", quer dizer, ouvidos e coração ${ }^{104}$. Embora para a maior parte das pessoas, hoje, o que toca os sentidos é muito mais real e presente do que o que toca o coração, ou mesmo a mente, para Agostinho, de modo nenhum: a presença divina, sua Palavra, direcionada ao coração, era muito mais íntima e presente do que qualquer palavra humana, voltada unicamente aos ouvidos da carne, porque "depois que o ar é verberado, elas de imediato passam, não permanecendo mais do que [o tempo em que] soam"105. Todavia a Palavra de Deus, posto que seja proferida, não passará:

[...] Também nós dissemos palavras, visto que falássemos. Acaso era uma palavra deste tipo que estava junto a Deus? E acaso não soaram e passaram as palavras que dissemos? Logo também a Palavra de Deus soou e se completou? De que modo todas as coisas foram feitas por ela, e sem ela nada foi feito? De que modo por ela é regido tudo o que por ela foi criado, se soou e passou? Então de que qualidade é esta Palavra, que foi dita e não passou? Que a vossa caridade preste atenção: trata-se de um [assunto] grandioso. Ao dizê-las cotidianamente, as palavras se nos tornaram vis, porque, soando e passando, elas se envileceram, e nenhuma outra coisa parecem ser do que palavras. Há uma palavra também no próprio homem, que permanece dentro dele, visto que o som procede de sua boca. Há uma palavra que se diz verdadeiramente espiritual, que é aquilo que tu inteliges a partir do som, não o próprio som. Eis a palavra que eu digo, quando digo "Deus". ${ }^{106}$

A palavra humana soa e passa. Ela procede da boca como voz, mas é gestada no homem interior. Não nasce em sua boca, mas em seu espírito. Da boca saem apenas sopros, os sons da

\footnotetext{
${ }^{103}$ In Ioh. 1,7: [...] et de pectore domini bibebat quod propinaret nobis, sed propinauit uerba. intellectum autem inde debes capere, unde et ipse biberat, qui tibi propinauit, ut leues oculos ad montes, unde auxilium ueniet tibi, ut inde tanquam calicem, id est, uerbum propinatum, acciperes.

${ }^{104}$ In Ioh. 1,7: sed forte hoc dicetis, quia ego uobis sum praesentior quam deus. absit! multo est ille praesentior, nam ego oculis uestris appareo, ille conscientiis uestris praesidet. ad me aures, ad illum cor, ut utrumque impleatis.

${ }^{105}$ D.C. 2,4,5: [...] quia uerberato aere statim transeunt nec diutius manent quam sonant...

${ }^{106}$ In Ioh. 1,8: [...] et nos diximus uerba, cum loqueremur. numquid tale uerbum erat apud deum? nonne ea quae diximus sonuerunt atque transierunt? ergo et dei uerbum sonuit et peractum est? quomodo omnia per ipsum facta sunt, et sine ipso factum est nihil? quomodo per illud regitur, quod per illud creatum est, si sonuit et transiit? quale ergo uerbum quod et dicitur et non transit? intendat caritas uestra: magna res est. quotidie dicendo uerba uiluerunt nobis, quia sonando uerba et transeundo uiluerunt, et nihil aliud uidentur quam uerba. est uerbum et in ipso homine, quod manet intus, nam sonus procedit ex ore. est uerbum quod uere spiritaliter dicitur, illud quod intellegis de sono, non ipse sonus. ecce uerbum dico, cum dico "deus"...
} 
voz que o vento carrega consigo. Essa palavra que sai da boca é carnal, porque soa aos ouvidos, porque soa e passa, como tudo o que é corpóreo. Contudo a palavra interior, espiritual, que se diz "palavra" também, ainda que saia da boca de um falante em direção aos ouvidos de um ouvinte, não é o que se ouve por meio dos ouvidos, mas o que se compreende com a inteligência (intellegere) a partir do que se ouve, permanecendo no homem interior. Quando se diz que Deus é Palavra, não é obviamente numa palavra como a que soa e passa que se deve pensar, mas numa palavra do tipo dessa, espiritual. No entanto, nem mesmo o que é significado pela palavra "Deus" é lícito dizer que seja o próprio Criador, como o rétor já havia dito em outros escritos ${ }^{107}$, não porque a palavra não aponte para ele, mas porque ele é incognoscível em si mesmo, ainda que dele se possam dizer, contudo de modo impróprio e apofático, muitas coisas. Na verdade, quando essa palavra soa, como ele explica no De doctrina christiana, o ouvinte é levado a pensar coisas extremamente complexas, que nem seria adequado desenvolver no gênero homilético, como é o destes tratados acerca da narrativa joanina. Todavia o que interessa investigar aqui é apenas se isso tudo que se pensa, quando se pensa a palavra "Deus", se isso também é palavra, quer dizer, conteúdo articulado e ordenado sintaticamente de natureza lógica e linguística. Se se leve em conta o que se disse na referida obra, talvez seja possível sustentá-lo, pois quando se ouve a palavra "deus" toda uma gama de operações lógico-sintáticas se põem em movimento na mente do ser pensante, nada parecido com uma imagem simples de algum objeto perceptível pelos sentidos, como uma árvore ou um cavalo. Porém a questão era muito mais complexa e profunda para o filósofo, indo muito além da aplicação de uma figura retórica para fazer a apologia do dogma da Encarnação, sua importância se depreendendo pela insistência com que ele retoma o exemplo, obra após obra a ruminar o tema: o que é que se pensa quando se pensa no Infinito, no Inefável, no Absoluto, no Eterno? Numa palavra, como a mente, presa às cadeias do tempo e do espaço, que opera com palavras que têm começo e fim, com imagens mentais originadas das percepções dos sentidos corpóreos, enfim, como esse instrumento, posto que de natureza inteligível e incorruptível, porém sem dúvida temporal, pode pensar algo atemporal e infinito ${ }^{108}$ A partir do prisma exclusivo da linguagem, se o queira, a questão se dirige

\footnotetext{
${ }^{107}$ Cf. Sermo $288 \S 3 ;$ D.C. $1,6,6$.

${ }^{108}$ No Tractatus (4.114) Wittgenstein afirma que o impensável se delimita através dos limites encontrados para o pensável (durch das Denkbare begrezen), daí a filosofia apontar para o indizível ao representar com clareza o dizível (4.115). Porém na sequência (5.6) acrescenta: "Os limites da minha linguagem significam os limites do meu mundo" (Die Grenzen meiner Sprache bedeuten die Grenzen meiner Welt), pois $(5,61)$ o que não se pode pensar, isso não pode ser pensado; o que não se pode dizer, isso tampouco pode ser pensado (Was wir nicht denken können, das können wir nicht denken; wir können also auch nicht sagen, was wir nicht denken können). Portanto o seu mundo consiste apenas no que cada um pode dizer e, consequentemente, pensar (5.621). No entanto ele reconhece (6.4312) ao final, de modo um tanto misterioso, que a solução do enigma da vida no espaço e no tempo
} 
para a referência: como pode um signo significar algo que não se sujeita à significação, sendo suprassignificável?

[...] Quão breve é isso que eu disse? Quatro letras e duas sílabas. E acaso isto tudo é que é Deus, quatro letras e duas sílabas? E isto é tão vil quanto caro é aquilo que nelas se intelige? Que é que se fez em teu coração quando tinhas ouvido: "Deus"? O que é que se fez em meu coração quando eu disse: "Deus"? Pensou-se uma certa substância, grande e suprema, que transcenda toda criatura mutável, carnal e dotada de alma... ${ }^{109}$

Quando ouve a palavra "Deus", para além dos sons, audíveis e transitórios, o espírito vê suscitado em si algum conteúdo, neste caso tão mais elaborado quanto abstrato, que movimenta suas faculdades inteligentes. A palavra "Deus" não se remete diretamente a nenhum referente, precisamente porque o referente é irreferível, pois inapreensível e inconcebível. Contudo ela suscita, quer na mente idônea, isto é, depurada do apego aos sentidos, quer na mente dos que aos corpos se atêm, pensamentos os mais complexos, que ultrapassam em muito qualquer experiência sensorial. De fato, que é substância, que se possa apontar com o dedo ou dizer com uma única palavra? Ou ainda, que é o adjetivo substantivado "grande" (magnus), que possa ser compreendido sem alguma operação lógica que envolva no mínimo duas coisas comparadas, a não dizer de outros conceitos correlatos, como pequeno, médio, maior, e de suas implicações, que no caso divino, contudo, se fazem ainda mais diáfanas, visto que os adjetivos quase todos se aplicam apenas de modo derivado ao que não se delimita espacialmente? O mesmo se pode dizer de outros pseudopredicados que se justapõem a Deus, ainda que de modo impróprio:

[...] E se eu te diga [pergunte]: Deus é mutável ou imutável? Responderás de pronto: longe de mim crer ou sentir que Deus seja mutável; Deus é imutável. A tua alma, embora pequena, embora talvez ainda carnal, não pôde responder-me senão que Deus é imutável. Porém toda criatura é mutável. Então de que modo pudeste cintilar até aquilo que está acima de toda criatura, de modo que me respondesses com certeza que Deus é imutável? Que é isso que há em teu coração quando pensas numa certa substância viva, perpétua, onipotente, infinita, ubiquamente presente, ubiquamente inteira, em parte alguma encerrada?... ${ }^{110}$

está fora do espaço e do tempo (Die Lösung des Rätsels des Lebens in Raum und Zeit liegt außerhalb von Raum und Zeit).

${ }^{109}$ In Ioh. 1,8: [...] quam breue est quod dixi? quattuor litteras et duas syllabas. numquidnam hoc totum est deus, quattuor litterae et duae syllabae? an quantum hoc uile est, tantum carum est quod in eis intellegitur? quid factum est in corde tuo, cum audisses "deus"? quid factum est in corde meo, cum dicerem "deus"? magna et summa quaedam substantia cogitata est, quae transcendat omnem mutabilem creaturam, carnalem et animalem...

${ }^{110}$ In Ioh. 1,8: [...] et si dicam tibi: deus commutabilis est an incommutabilis? respondebis statim: absit, ut ego uel credam uel sentiam commutabilem deum; incommutabilis est deus. anima tua, quamuis parua, quamuis forte adhuc carnalis, non mihi potuit respondere nisi incommutabilem deum. omnis autem creatura mutabilis. quomodo ergo potuisti scintillare in illud quod est super omnem creaturam, ut certus mihi responderes incommutabilem deum? quid est illud in corde tuo, quando cogitas quamdam substantiam uiuam, perpetuam, omnipotentem, infinitam, ubique praesentem, ubique totam, nusquam inclusam? 
No entanto quem cogita essas coisas todas que coisa cogita, para além de palavras? Como explicar tais conceitos, como imutabilidade, substância vivente, perpetuidade, onipotência, infinito, ubiquidade, integralidade, presença, superveniência? Quem cogita isso tudo é indubitável que cogite, ao menos em primeiro plano, palavras, pois, ainda que se objete que nem todo movimento do espírito é cognitivo, ninguém há que não admita que neste caso se trata exclusivamente de movimentos cognitivos. Demais, como se há de ver adiante, certos movimentos do espírito se admitem, quando asceticamente se busca algum tipo de êxtase contemplativo, que, embora incoados pela razão, ultrapassam-na ao ser alcançada uma determinada condição suprarracional, por assim dizê-lo. Neste nível mental, contudo, Agostinho refere-se inequivocamente aos movimentos cognitivos da mente, os quais se descrevem por meio de palavras apenas, ainda que elas conduzam, em última instância, ao silêncio da Palavra inefável.

[...] Quando cogitas essas coisas, é isto a Palavra [que procede] de Deus em teu coração. E acaso, pois, isto é aquele som, que consta de quatro letras e de suas sílabas?... ${ }^{111}$

Note-se que Agostinho não está dizendo que esses pensamentos, que se suscitam no coração daquele que ao ouvir a palavra "Deus" põe-se a pensar, são a Palavra de Deus, mas que eles são "a palavra de Deus em seu coração" (uerbum de deo in corde), quer dizer, a palavra que procede de Deus (de deo) e que se permite tomar forma no coração humano, quer dizer, na mente racional. Não se trata da própria Palavra eterna de Deus que se fez carne e que presidiu à criação do mundo, mas a Luz da Verdade que brilha (scintillo) no coração daquele que se põe a pensar a respeito do inefável e incognoscível a partir do signo linguístico "Deus"112. Pois bem, quem é que pode apontar aqui o referente? E quem é que pode dizer que, para Agostinho, é a coisa que se encontra na mente, o próprio Deus? Talvez nem mesmo se possa dizer que seja uma imagem sua, um rasto seu, um seu vestígio, mas apenas reflexo da Luz emanada por ele, que se faz brilhar, com mais ou menos intensidade, o que depende da capacidade e da pureza (desprendimento dos sentidos) da mente de cada cogitabundo. Esses pensamentos não são matéria sonora, pois nada corpóreo pode penetrar a natureza inteligível da mente, mas sem dúvida constam de palavras de natureza mental, como que “imagens acústicas" articuladas,

\footnotetext{
${ }^{111}$ In Ioh. 1,8: [...] quando ista cogitas, hoc est uerbum de deo in corde tuo. numquid autem hoc est sonus ille, qui quattuor litteris constat et duabus syllabis?

${ }^{112}$ Cf. Plotino, Enéadas 5,3,14: "De que modo então nós podemos dizer dele? Na verdade, dizemos algo a respeito

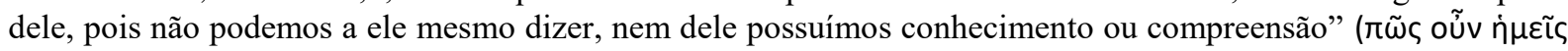

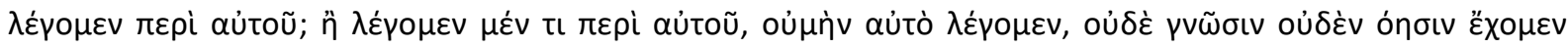
aủtoũ).
} 
sintaticamente ordenadas segundo a língua que o ser pensante domina, além de logicamente estruturadas em operações nada simples.

[...] Portanto todas as coisas que se dizem e passam são sons, letras e sílabas. Esta palavra que soa, passa. Porém o que significa o som, que não está apenas naquele que pensa, o [sujeito] que disse, mas também está naquele que intelige, o [sujeito] que ouviu, isto permanece, depois que os sons passam. ${ }^{113}$

As palavras carnais, vozes que soam e passam, são constituídas de vibrações sonoras articuladas em letras e sílabas. Porém elas são também signos, precisamente porque significam, contudo neste caso não algum objeto significável (res significabilis), e sim operações mentais igualmente significantes, as quais são suscitadas na mente daquele que pensa e depois diz o que pensou, mas também naquele que ouve os sons significantes que suscitam semelhantes operações mentais em sua própria mente, de acordo com a matéria-prima com que lhe é permitido trabalhar, ou seja, o tesouro que tem disponível na própria memória ${ }^{114}$. Porém, ao dizer que os signos se distinguem de seus significados correspondentes, não parece estar dizendo o filósofo que a mente racional opere exclusivamente com eles, os significados, como se o fizesse por imagens e não com os próprios signos, em sua forma mental, ou seja, que as palavras articuladas

${ }^{113}$ In Ioh. 1,8: [...] ergo quaecumque dicuntur et transeunt, soni sunt, litterae sunt, syllabae sunt. hoc uerbum transit, quod sonat. quod autem significauit sonus, et in cogitante est qui dixit, et in intellegente est qui audiuit, manet hoc transeuntibus sonis.

${ }^{114}$ No décimo livro das Confissões $(10,8,12)$, ao descrever os tesouros preservados nos campos e latos pretórios da memória, tesouros de inumeráveis imagens (innumerabilium imaginum), Agostinho diz que ali foi escondido tudo o que pensamos (quidquid etiam cogitamus), conteúdo que pode ser aumentado ou diminuído, variando a imagem das coisas que foram captadas pelos sentidos (uariando ea quae sensus attigerit...), tais como $(10,8,13)$ : (1) a luz e todas as cores e formas dos corpos captadas através dos olhos; (2) todos os sons captados através das orelhas; (3) todos os odores inalados através do ádito das narinas; (4) todos os sabores gostados através do ádito da boca; (5) o que é duro, o que é mole, o que é cálido, frio, suave ou áspero, pesado ou leve. Contudo não são as próprias coisas que entram na memória, mas as imagens das coisas captadas pelos sentidos (rerum sensarum imagines), as quais ali estão à disposição do pensamento (illic praesto sunt cogitationi), que as recorda. Porém o tesouro da memória não se limita ao que é apreendido pelos sentidos do corpo $(10,9,16)$, visto que ali se encontram também os conteúdos todos que foram adquiridos pelo estudo das doutrinas liberais, se ainda não caíram no esquecimento. Neste caso não se trata de figuras, mas das próprias coisas, quer dizer, do próprio conteúdodas doutrinas, que se constitui algo inteligível, não corpóreo. Essas coisas foram aprendidas, mas visto que são de natureza inteligível, restam no espírito íntegras, quer dizer, não as imagens delas, como as imagens das coisas corpóreas vistas ou tocadas, mas elas mesmas. Por exemplo, Agostinho diz $(10,10,17)$ que quando ouve que três são os gêneros de questões (at uero cum audio tria genera esse quaestionum): [1] se é, [2] o que é [3] e de que qualidade é (an sit, quid sit, quale sit), retém as imagens dos sons com os quais estas palavras foram confeccionadas (sonorum quidem quibus haec uerba confecta sunt imagines), sabendo que os sons atravessaram os ares (et eos per auras) com ruído (cum strepitu transisse) e agora já não são mais (ac iam non esse scio). Porém as próprias coisas (res uero ipsas), que com aqueles sons são significadas (quae illis significantur sonis), nem as atingiu por meio de algum sentido do corpo (neque ullo sensu corporis attigi), nem as viu em algum lugar (nec uspiam uidi) além do seu espírito, e todavia em sua memória as preservou (in memoria recondidi), não as imagens delas (non imagines earum), e sim as próprias coisas (sed ipsas), as quais, a partir de onde puderam penetrar-lhe o espírito (quae unde ad me intrauerint), que digam aqueles que puderem fazê-lo (dicant si possunt)! Os números $(10,12,19)$ também são armazenados na memória, mas não como uma lista quantitativa, e sim as razões deles e suas dimensões (numerorum dimensionumque rationes), além de suas inumeráveis leis (leges innumerabiles); e esse conteúdo não foi apreendido pelos sentidos. 
se restrinjam ao proferimento vocal, como se fossem exclusivamente lógoi prophorikoí. Com efeito, havia dito no Sermo 288: “eu cogitava então 'Deus'... ainda não soou a voz em minha boca e a palavra já está contida no meu coração...”, onde está claro que não se refere apenas ao que ela significa, mas também à própria palavra "Deus", o que implica a presença da palavra articulada em sua mente, como imagem acústica, se se permita dizê-lo. Demais, quando diz no mesmo Sermo 288 que buscava palavras latinas ou gregas para exprimir o que pensava, onde é que as buscava, senão no dicionário da memória, em seu próprio espírito? Ora, não buscou ali significados, mas palavras estruturadas num determinado sistema linguístico. E ainda que ele mesmo refira aquela palavra que não pertence a nenhuma língua, ao fazê-lo nada mais parece estar pretendendo do que simplesmente distinguir os movimentos cognitivos da mente racional humana, imersos nas cadeias do tempo, da própria Verdade imutável de Deus, supratemporal, supralinguística, suprarracional. O que não acontece na língua circundada de dentes, mas exclusivamente no homem interior, porque é lógos endiáthetos, a despeito da compartimentalização que se possa fazer do espírito, ao situar a memória num lugar à parte, ou estabelecer a razão como instrumento da mente. Parece haver evidências bastantes, portanto, para sustentar a tese de que para ele as palavras se encontram também guardadas na memória, de onde são retiradas para ser trabalhadas pela mente racional, como se pode comprovar pelo que disse no De magistro, que as palavras aderem à memória, as quais são ali buscadas pela mente racional para serem revolvidas, juntamente com o que significam ${ }^{115}$. E se assim é de fato, o que a palavra "Deus" significa, ao menos para a mente cognitiva, em sua racionalidade, não se constitui senão de palavras, ou então só se compreende por meio de delas, ao menos hic et nunc. Portanto os pensamentos suscitados na mente a partir da audição do signo "Deus", "as palavras de Deus no coração" (uerbum de deo in corde), é lícito dizer, ao contrário da Palavra eterna a partir de onde eles são suscitados, constituem-se de palavras e sentenças, operações lógicas ordenadas sequencialmente.

\section{In speculo mentis}

O que é que o Filho ouve do Pai, indaga Agostinho, em referência a Jo 3,11-13, que pretende na sequência comentar com seus ouvintes ${ }^{116}$ : "Quando é que a minha língua, quando

\footnotetext{
${ }^{115}$ Mag. 1,2: cum memoria, cui uerba inhaerent, ea reuoluendo...

116 Jo 3,11: "Amém! Amém! Eu te digo que falamos aquilo que sabemos, e que testemunhamos o que vimos..."

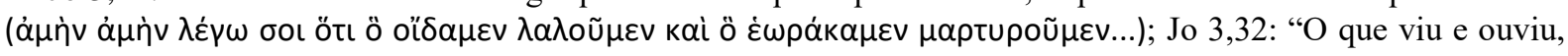


é que meu coração pode ser suficiente, seja o coração para compreender, seja a língua para proferir aquilo que o Filho ouviu do Pai?" "117 Trata-se indubitavelmente de uma questão bastante espinhosa, pois, se o Filho é a Palavra do Pai, de que modo se diz que ouviu a Palavra, a não ser que se permita imaginar que tenha ouvido a si mesmo?

Talvez o Filho tenha ouvido a Palavra do Pai? De modo algum, o Filho é a Palavra do Pai. Vedes de que modo aqui se afadiga todo o esforço humano; vedes como aqui é deficiente toda a conjectura de nosso peito e toda a atenção de nossa mente caliginosa. Ouço a Escritura dizer que o Filho fala o que ouve do Pai, e também ouço dizer que o próprio Filho é a Palavra do Pai... ${ }^{118}$

No entanto, se o Filho é a Palavra do pai, sendo as palavras transitórias, soando umas sílabas após o fenecimento das outras, de que modo o Filho pode ser assim descrito, como sendo esse gênero de palavra? Não poderia, sem dúvida. Por isso deve haver uma palavra de outra natureza, que, nada obstante ser palavra, permaneça:

[...] Nós falamos palavras que voam e que passam; assim que a tua palavra soar por tua boca, ela passa, termina o seu ruído e passa ao silêncio. Acaso podes seguir o teu som e retê-lo, de modo que ele fique parado? Contudo o teu pensamento permanece, e a partir do teu pensamento, que permanece, tu dizes muitas palavras que passam... ${ }^{119}$

Não se pode trazer de volta uma palavra saída da boca, nem fazê-la pairar no ar, mesmo que se empregue o recurso, hoje disponível, de um mecanismo qualquer de registro de voz. Com efeito, ainda que se reproduza indefinidas vezes uma palavra gravada, ela só será a palavra que foi destinada a ser depois que cumpra a sua sina: fazer morrer, uma após as outras, as sílabas que a constituam. E se se diga que o mesmo se dá no pensamento, visto que ali também as palavras, silenciosas, ainda que retidas na memória, devem cumprir a sua sina, sílaba após sílaba, contudo a ideia aqui é muito mais de fundo filosófico que linguístico, embora suas implicações sirvam ao propósito pretendido. O rapsodo homérico não pôde recitar versos de uma epopeia de sua preferência depois de morto, posto que os versos, se registrados na memória de um papiro, por assim dizê-lo, pudessem ser publicados por outro poeta depois dele. Isso porque

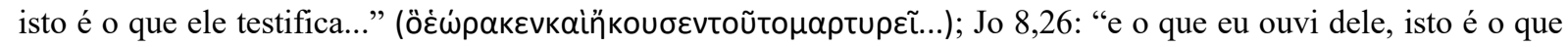

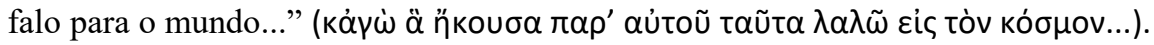

${ }^{117}$ In Ioh. 14,7: Quando lingua mea, quando cor meum sufficere potest, uel cor ad intelligendum, uel lingua ad proferendum quid est quod filius audiuit a patre?

118 In Ioh. 14,7: [...] Forte filius uerbum patris audiuit? imo, filius uerbum a patre est. uidetis quemadmodum hic fatigetur omnis conatus humanus, uidetis quemadmodum hic deficiat omnis coniectura pectoris nostri et omnis intentio mentis caligantis. audio dicentem scripturam quia filius hoc loquitur quod audit a patre et rursus audio dicentem scripturam quia ipse filius uerbum patris est...

${ }^{119}$ In Ioh. 14,7: [...] nos loquimur uerba uolantia et transeuntia; mox ut sonuerit ore tuo uerbum tuum, transit, peragit strepitum suum et transit in silentium. numquid potes sequi sonum tuum et tenere ut stet? cogitatio tamen tua manet et de ipsa cogitatione manente dicis multa uerba transeuntia... 
a voz do primeiro foi-se para sempre, ainda que signos que se remetam mediatamente ao conteúdo cantado tenham permanecido no papiro. Assim se dá com todas palavras corpóreas, sons que o vento leva, sua natureza, ainda que artificialmente preservada por mecanismos quaisquer, contudo está inexoravelmente destinada à corrupção, cedo ou tarde. A natureza inteligível, por sua vez, ainda que os pensamentos também se sucedam uns aos outros na mente, seja na forma de imagens, seja na forma de signos de natureza linguística, diz Agostinho que é permanente. Porém o que permanece não são as atividades contingentes da mente racional, seus movimentos cognitivos, mas o próprio espírito, e o que partilhe de sua natureza destinada à eternidade, desde que idônea para tanto. De que modo permanece, se o espírito também se movimenta e modifica no tempo $?{ }^{120}$ Permanece o espírito desde que adira à natureza eterna de seu Criador, assim como permanece o pensamento que adira à Verdade eterna ${ }^{121}$. Mas se é assim, objeta-se, não sem razão, quando diz que é a partir do pensamento que permanece que se dizem as muitas palavras que não permanecem, de que modo permanece, se esse pensamento é também impermanente? Se não é permanente como a Verdade imutável de Deus, como de fato não o é, contudo sua natureza é mais permanente do que a natureza das palavras que dele se originam. Daí ter dito que o pensamento permanece, porque, além de ser de natureza inteligível, imagem e semelhança da Natureza eterna, também pode permanecer por tempo indefinido, certamente por tanto tempo quanto seja retido na memória.

Pois bem, se João diz que o Filho ouviu algo do Pai, por certo ouviu-lhe palavras, o que se permite supor teriam sido proferidas em alguma língua. Porém em que língua falou Deus? Se sua morada é fora do tempo, sendo ele eterno, de que modo poderia ter falado com sons articulados, que são de natureza corpórea e múltipla, visto cada palavra constituir-se de letras e sílabas que se sucedem e passam?

[...] Que é que estamos dizendo, irmãos? Que Deus, quando falou, empregou a voz? empregou os sons? empregou sílabas? Se empregou todas essas coisas, em que língua falou? Hebraica? Grega? Latina? É necessária uma língua ali, onde há distinção de pessoas. Porém ninguém pode dizer ali [onde não há distinção], que Deus tenha falado aquela ou aquela outra língua... ${ }^{122}$

\footnotetext{
${ }^{120}$ Cf. De trinitate 9,6,9. Quando a mente humana se conhece e se ama a si própria, ela não conhece nem ama algo imutável, mas algo mutável (sed cum se ipsam nouit humana mens et amat se ipsam, non aliquid incommutabile nouit et amat).

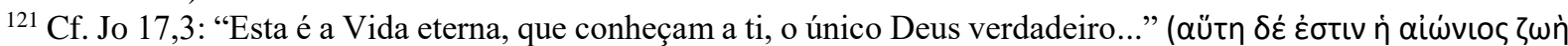

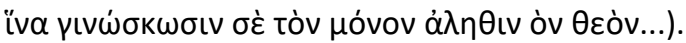

122 In Ioh. 14,7: [...] quid dicimus, fratres? deus, cum loqueretur, adhibuit uocem, adhibuit sonos, adhibuit syllabas? si adhibuit ista, qua lingua locutus est? Hebraea? an Graeca? an Latina? ibi necessaria lingua, ubi distinctio gentium. ibi autem nemo potest dicere, illa lingua, uel illa lingua locutus esse deum..
} 
Nada obstante essa homilia ter sido proferida ad catechizandos rudes, para educar os simples na fé, ao tornar-lhes mais compreensível o conteúdo do Evangelho, suas palavras não apenas deleitam os ouvidos daqueles corações que persuadem, mas servem a propósito filosófico ulterior, ao tornar claro, por meio dos recursos retóricos que emprega, um tema que será tratado com tanto mais rigor quanto dificuldade no De trinitate.

Portanto quando concebes uma palavra para dizê-la, queres dizer uma coisa, e a pró-
pria concepção da coisa em teu coração já é uma palavra; ainda não saiu [de tua boca],
mas já nasceu no coração, e [ali] permanece, para que [dali] saia. Porém tu te voltas
para aquele em direção ao qual ela sai [da tua boca], com o qual tu estejas falando. Se
é latino, procuras uma voz latina; se grego, meditas palavras gregas; se púnico, pro-
curas se conheces a língua púnica. Empregas línguas diversas de acordo com a diver-
sidade dos ouvintes, de modo que profiras a palavra que foi concebida. Porém aquilo
que havias concebido no coração, não estava retido em nenhuma língua.... ${ }^{123}$

Há sem dúvida aqui a referência a um conteúdo anterior que deve ser convertido em linguagem para que seja comunicado, como a passagem deixa inequivocamente claro. E neste caso, diferentemente das vezes em que se socorreu da palavra "Deus", cujo significado é bastante problemático, aqui Agostinho parece estar referindo uma palavra qualquer, sem estatuto diferenciado. Pois bem, quem quer dizer alguma coisa, conteúdo que Agostinho considera já uma palavra, mesmo que ainda não tenha sido pronunciada pela boca, concebe isso no coração, onde faz morada, até que o espírito o ponha para fora vocalmente. Esse movimento do espírito, que se diz "palavra", mas que ali não se encontrava em língua nenhuma, diz o filósofo, expressa não apenas o rebento do coração, mas também o desejo de dizê-lo (rem uis dicere), uma vontade (uelle) de comunicá-la a outrem. A conversão desses movimentos do espírito em linguagem, contudo, não é feita na boca, como algumas vezes reiterado, mas no próprio espírito, de modo preciso na mente racional, que vai buscar à memória o conteúdo ali armazenado, depois que foi concebido no coração. Por outra, muita vez entre a concepção da palavra do coração, o querer dizê-la, a conversão em linguagem e a própria palavra que sai da boca, o intervalo de tempo é nulo, ou parece ao espírito que o seja. Demais, é também na mente que se encontram as palavras que serão usadas, seja em que língua for, para que possam ser proferidas na forma de uma língua qualquer. Agora, o que torna as coisas mais complicadas é o fato de que nem todos os movimentos do espírito são cognitivos, pois ao lado dos argumentos mais elaborados, das construções sintaticamente complexas, com vários níveis de subordinação, das deduções e induções de

\footnotetext{
${ }^{123}$ In Ioh. 14,7: [...] quando ergo concipis uerbum quod proferas, rem uis dicere, et ipsa rei conceptio in corde tuo iam uerbum est; nondum processit, sed iam natum est in corde, et manet ut procedat. adtendis autem ad quem procedat, cum quo loquaris; si Latinus est, uocem Latinam quaeris; si Graecus, uerba Graeca meditaris; si Punicus, adtentis si nosti linguam Punicam; pro diuersitate auditorium diuersas linguas adhibes, ut proferas uerbum conceptum. illud autem quod corde conceperas, nulla lingua tenebatur...
} 
todos os tipos e níveis de complexidade, há vontades dissimuladas, desejos desordenados, sentimentos multifacetados, inclinações de toda ordem, que não se pode dizer sejam completamente convertíveis em linguagem, e talvez nem que sejam suscitadas a partir dela. $\mathrm{O}$ que se permite dizer disso, no fim, é apenas que esse conteúdo que foi concebido na mente e que se desejou comunicar, se de natureza cognitiva, não se consegue vislumbrar de que modo poderia ser cogitado fora do universo linguístico; contudo também é permitido reconhecer que o espírito não está limitado pela linguagem, pois o conteúdo mental vai muito além das operações racionais que podem ser analisadas sistematicamente, visto que, ao menos para Agostinho, ele era mais do que o corpo que habitava ${ }^{124}$. Portanto, se nem tudo o que se queira dizer nasce como linguagem, havendo movimentos do espírito que precisam tomar forma para ser expressos, parece inegável também que o movimento de tipo cognitivo não se dê fora dela, no interior da mente racional, no tempo. Todavia, ainda que a citação acima referisse uma palavra qualquer, sem o caráter especial da palavra "Deus", contudo isso não pode ser destacado do contexto da passagem, visto que o único propósito do rétor, como a sequência deixa claro, não é tecer considerações acerca da concepção da linguagem humana, mas fazer uma analogia entre a Palavra eterna de Deus e as palavras humanas ad catechizandos rudes:

Portanto, visto que Deus, ao falar, não procurasse uma língua e não assumisse um tipo de fala, de que modo foi ouvido pelo Filho, uma vez que Deus tenha falado o próprio Filho? E de que modo tu tens no coração a palavra que tu falas, e ela está junto a ti, e a própria concepção dela é espiritual — pois assim como a tua alma é espírito, assim também a palavra que concebeste é espírito - ; pois tu ainda não acolheste o som para que [a palavra] seja dividida em sílabas, mas permanece na concepção do coração e no espelho da mente, assim também Deus publicou sua Palavra, isto é, gerou seu Filho. ${ }^{125}$

A palavra que permanece na concepção do coração (in conceptione cordis) e no espelho da mente (in speculo mentis) ainda não se fez sonora (nondum accepit sonum) de modo a que pudesse ser proferida pela boca em sua forma articulada, dividida em sopros de voz, ou seja, sílabas (per syllabas diuidatur). Mas, afinal, que é essa palavra do coração? Dizê-la espiritual ajuda um pouco. Talvez, se se permita especular, Agostinho queira compará-la ao espírito, que

\footnotetext{
${ }^{124} \mathrm{O}$ paralelo é imprescindível: assim como o homem é mais que o corpo que habita, sua parte de menor valor, do mesmo modo a linguagem é mais do que as palavras corpóreas, cuja forma, sonora, constitui sua parte de menor valor, pois assim como o homem ressurrecto que vier a contemplar a face de Deus, que é espírito, o fará revestindo

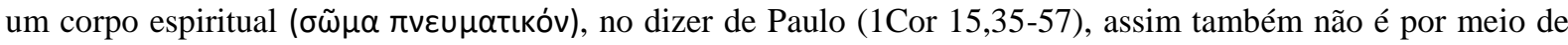
palavras carnais que se imagina ouvir a pregação de Cristo no terceiro céu (2Cor 12,2-4).

${ }^{125}$ In Ioh. 14,7: [...] cum ergo deus loquens, linguam non quaereret, et genus locutionis non adsumeret, quomodo auditus est a filio, cum ipsum filium sit locutus deus? quomodo enim tu uerbum quod loqueris in corde habes, et apud te est, et ipsa conceptio spiritalis est - nam sicut anima tua spiritus est, ita uerbum quod concepisti spiritus est -; nondum enim accepit sonum ut per syllabas diuidatur, sed manet in conceptione cordis et in speculo mentis, sic deus edidit nerbum, hoc est, genuit filium...
} 
adentra o universo corpóreo ao assumir uma veste de carne, assim como a palavra toma corpo ao assumir sua veste carnal, os sons articulados em sílabas e letras. Por outra, pode-se estender a analogia, ao apontá-la para a unidade do espírito, para fazer ver como se distinguem as palavras corpóreas, em sua multiplicidade de sílabas e letras, da palavra espiritual, de cuja suposta unidade nada se disse, ao menos aqui. Dizê-la "espelho da mente", por fim, talvez esclareça um tanto mais a questão. Pois bem, que faz o espelho, senão refletir? E que reflete, neste caso, com exceção da mente? Logo, se as palavras concebidas no coração são espelho da mente, e se a mente é a potência raciocinadora do espírito, tem-se ou que as palavras do coração espelham o poder de raciocinar da mente, ou que a mente espelha o que se concebe no coração. Porém a mente é anterior às palavras do coração, que foram concebidas para ser revolvidas por ela, não o contrário; e ninguém concebe palavras se destituído de sua mente. Demais, Agostinho não diz que a mente é o espelho das palavras, e sim o contrário. Portanto as palavras é que refletem o que se encontra na mente. E na mente humana, que é uma potência do espírito, reside a própria capacidade de pensar, de produzir conteúdos cognitivos. Logo as palavras, se espelham a mente, espelham suas possibilidades cognitivas. E que se pode depreender disso que sirva aos propósitos aqui determinados, de investigar a relação entre as palavras e o pensamento? De par com o que se elucubrou, além do fato de que essas palavras, apesar de serem espirituais, são múltiplas, pois geradas no tempo, têm começo e fim, ao contrário da Palavra de Deus, que foi gerada antes do tempo, o qual ela mesma criou, a possibilidade de que sejam, in quantum espelho da mente, não os significados de uma suposta língua universal, conteúdos subjacentes a todas as línguas, mas, de um lado o conhecimento derivado das eternas razões, regras imutáveis da verdade, de outro o próprio conectá-las, operando ao modo de um mecanismo que relaciona e ordena os conteúdos entre si, produzindo a intelecção, e que, assim como a reta razão, com que se identifica, se é de algum modo anterior à linguagem, contudo, como a Palavra que se fez carne, opera através dela: "e tu por certo geras no tempo também a palavra no coração; Deus gerou o Filho sem tempo, através do qual criou todos os tempos. ${ }^{126}$ E se a superfície desse espelho ainda não se encontra suficientemente polida para refletir uma imagem nítida, é possível que o excerto das Confissões a ser comentado por último dê conta de fazê-lo.

${ }^{126}$ In Ioh. 14,7: et tu quidem ex tempore gignis uerbum etiam in corde, deus sine tempore genuit filium, per quem creauit omnia tempora. 


\section{De trinitate: imagens articuladas}

No nono livro do tratado acerca da Trindade, obra escrita no longo intervalo entre os anos 399 e 422/6, Agostinho compara o conhecimento de caráter empírico que se obtém através dos sentidos corpóreos com as razões eternas alcançadas pela contemplação, distinguindo os conteúdos mutáveis dos imutáveis na própria mente humana. Assim, tendo os sentidos corpóreos entrado em contato com os corpos apreensíveis e deles haurido suas aparências (phantasiae), ou seja, suas configurações exteriores perceptíveis, de algum modo elas são infundidas na memória, a partir das quais o que não mais se encontra presente aos sentidos pode ser pensado pelo espírito ad libitum, mas também o que nunca foi experienciado, o que se faz por meio das falsas aparições (phantasmata), quer dizer, representações que na mente se esculpem ${ }^{127}$. Essa modelagem, que pode não corresponder perfeitamente ao original, o qual nunca foi visto, ou corresponder apenas fortuitamente, contudo é julgada segundo as regras absolutamente supramentais da Verdade, as quais permanecem imutáveis para sempre. Por exemplo, quando quer recordar as muralhas de Cartago, diz Agostinho (Trin. 9,6,10), as quais ele bem conhecia, encontra na memória as aparências cartaginesas ali armazenadas a partir da própria experiência sensorial. Contudo, se quiser pensar nas muralhas de Alexandria, cidade que nunca havia visitado, seu espírito deve modelá-las; e porque não há imagem alguma em seu acervo memorizado do objeto que quer cogitar, essa modelagem é comparada a um espectro, verdadeira "aparição" (phantasma). Porém em ambos os casos, explica o filósofo, trata-se de formas imaginárias (imaginarias formas), seja a aparência das muralhas cartaginesas experienciadas sensorialmente, seja as alexandrinas mentalmente esculpidas. O juízo acerca de ambas, por sua vez, seja comparando umas às outras, seja comparando-as com um modelo idealizado, a fim de aprová-las ou de reprová-las, é sempre tarefa da razão.

Essa descrição da atividade mental, embora tenha sido suscitada a partir de perceptos obtidos dos sentidos, seja no caso das phantasiae, seja no caso dos phantasmata, torna-se sobremodo cognitiva quando a mente racional exerce sua prerrogativa de preferência, quer aprovando, quer reprovando as imagens mentais, ao cotejá-las com modelos idealizados. De fato, Agostinho nunca viu as muralhas de Alexandria, mas por uma operação de sua mente racional, que é capaz de, (1) reunindo as imagens das muralhas vistas por seus olhos, (2) de par com as informações que lhe chegaram aos ouvidos acerca da geografia de Alexandria e de sua história,

${ }^{127}$ Distinguiram-se aqui para efeito de análise os termos phantasia, "aparência", de phantasma, liter. "aparição", mas que se pode compreender como "representação", pois, se a primeira é captada pelos sentidos, como uma espécie de registro sensorial, a segunda é como que "esculpida" (fingere) pela mente racional. 
(3) e daí, através de operações racionais complexas, "aplicar" as regras imutáveis da Verdade, acima da mente humana, referentes à configuração de uma muralha padronizada, é capaz de moldar na mente o que seria a muralha de uma cidade em que nunca esteve. Isso tudo, note-se, é tarefa da mente racional, que se utiliza da memória e de sua própria capacidade intelectiva, além de recorrer às regras imutáveis da Verdade, as ideias e definições, absolutas e imutáveis. Portanto é a razão que compara as imagens mentais armazenadas na memória umas às outras, assim como é ela que modela uma imagem de muralha a partir de um modelo imutável de muralha cotejado com o conteúdo da memória. E se é assim, resta indaga também da natureza destes movimentos da razão, tendo em vista as operações que ela leva a cabo, se, como espelho da mente, é lógica e articulada, quer dizer, se realiza as operações supradescritas com ou sem o intermédio da linguagem.

Na sequência (Trin. 9,6,11), para reforçar os anteriores, o filósofo apresenta ainda outro exemplo acerca de um suposto arco que tenha sido bela e harmoniosamente lavrado. Pois bem, se tal arco foi algum dia percebido pelos sentidos, será possível revolver no espírito (animo reuoluere) aquilo que então foi anunciado à mente pelos olhos (nuntiata per oculos) e transfundido na memória (memoriaeque transfusa). Essa "revolução", por assim dizer, da aparência preservada na memória, permite à mente racional tornear um novo arco, ou seja, um arco imaginário (imaginarium conspectum), que não é a aparência que constava do acervo, mas uma como que "aparição" que se permite entrever na mente (aliud mente conspicio). Depois, quando o espírito quer emitir juízos acerca dessas aparências e aparições, ambas formas imaginárias, é com o olhar da mente racional que o faz. Portanto três são os modos de apreensão de conteúdos para serem processados pela mente: (1) os sentidos do corpo, que tocam as coisas imediatamente, se lhe estão presentes; (2) a memória, que retém as aparências das coisas experienciadas; (3) a própria mente racional, que, através de operações complexas, como comparar, julgar, discernir etc., modela imagens mentais a partir do cotejamento dos dados armazenados na memória, oriundos de experiências semelhantes, com as regras imutáveis da Verdade.

Vê-se, sem equívoco nenhum, que esses três modos de apreensão relacionam-se intimamente com a palavra, pois as vozes com significado também se apreendem pelo sentido da audição, formando daí imagens acústicas que se armazenam na memória, as quais, depois de revolvidas pela mente racional, podem ser modelada sem novas formas para serem comparadas com as regras imutáveis da verdade, que sejam daí julgadas. Porém o vocábulo "palavra" (uerbum) costuma significar mais de uma coisa. De fato, a palavra foi compreendida não apenas como um signo de natureza sonora que, depois de proferido por um falante, pode ser inteligido 
por um ouvinte, mas também como signo mental silencioso, de par com seu significado, a não dizer da palavra do coração, nascida da suprema e eterna Palavra. Porém no De trinitate $(9,10,15)$ Agostinho apresenta uma divisão tripartite de acepções, fazendo compreender a palavra dos seguintes três modos. Primeiro como algo que tem espaços de tempo (spatia temporum) ocupados por sílabas, quer estas se pronunciem (siue pronuntientur), quer apenas se pensem (siue cogitentur), ou seja, o signo de natureza sonora e mental. Depois como algo impresso no espírito (animo impressum), que é conhecido e que pode ser definido e proferido a partir da memória, o que se remete obviamente ao significado da palavra, àquilo para o que aponta o signo. Por fim como aquilo que se concebe na mente (mente concipitur), o que aponta para aquela palavra que não pertence a língua nenhuma, tendo nascido da Palavra eterna. $\mathrm{O}$ que importa notar aqui, acima de tudo, é que nenhuma delas se diz "palavra" por deficiência ou pobreza da língua, como tampouco seria justo dizê-lo do lógos grego, como se ambas as línguas, seja a helênica, seja a latina, padecessem de alguma indigência semântica ou léxica, mas porque os conceitos guardam relação íntima e inextricável uns com os outros. Com efeito, se o primeiro sentido aponta para os signos que se distendem no tempo, quer soem, quer silenciem, porque articulados, percebe-se sua inequívoca natureza linguística, deixando entrever que as palavras pensadas eram consideradas de natureza semelhante à das palavras faladas, ambas articuladas do mesmo modo, em sílabas e letras, quer soantes, quer silentes ${ }^{128}$. Depois, se se diz "palavra" daquilo que é impresso no espírito, que é objeto de conhecimento, que pode ser definido e proferido a partir da memória, percebe-se sem grande necessidade de esforço como sua natureza, se não se limita à do signo linguístico, muito menos a exclui ${ }^{129}$. Por fim, mesmo que se trate daquela palavra anterior a toda língua de comunicação, contudo, porque convertível nela, não se pode dizê-la de todo dissociada de sua natureza cognitiva, visto que, embora nascida da Palavra eterna, simples e una, contudo dela se distingue, seja pela temporalidade, seja pela multiplicidade.

\footnotetext{
${ }^{128}$ Cf. Trin. 10,1,2. O trissílabo latino tēmètum, "vinho", desde que seu significado seja conhecido (notum), quando é proferido por alguém, faz com que sua imagem articulada (articulatam speciem suam) seja impressa no espírito (impressit animo) de um ouvinte, o que se fez através do sentido da audição (per sensum aurium). Ora, se lhe foi impressa no espírito uma "imagem articulada" do vocábulo trissilábico, tēe-mē-tum, parece evidente neste caso que lhe foi impressa no espírito uma palavra, mesmo que ela se remeta também, ad libitum, à imagem de uma deliciosa ânfora plena do melhor vinho de Falerno!

${ }^{129}$ De fato, se a palavra se compreende como "definição" (definitio) e "conhecimento" (notitia) - et hoc est uerbum eius (Trin. 9,10,15) —, difícil seria negar-lhe a natureza cognitivo-verbal.
} 


\title{
Palavra de língua nenhuma
}

\begin{abstract}
Portanto quem pode compreender aquela palavra, não apenas antes que soe, mas também antes que as imagens de seus sons sejam revolvidas pelo pensamento, palavra que a nenhuma língua pertence, daquelas, sem dúvida, que se chamam "línguas dos povos", das quais a nossa é latina; quem, digo, pode compreender isto, agora já pode ver através deste espelho e neste enigma alguma semelhança daquela Palavra, acerca da qual foi dito: "No princípio era a Palavra, e a Palavra era junto a Deus, e Deus era a Palavra". ${ }^{130}$
\end{abstract}

Essa palavra, anterior à palavra de natureza sonora, anterior também à palavra mental, que, depois de buscada à memória, é revolvida na mente racional, contudo não é aquela mesma eterna Palavra que se fez carne e habitou entre nós, ainda que sirva didaticamente para fazer vislumbrar, conquanto apenas em enigma e através de um espelho nada nítido, alguma semelhança dela. Mas se não é de natureza linguística, nem vocal, nem silenciosa, muito menos é a Palavra inefável de Deus, que palavra é ela? Ao contrário do que se costuma interpretar, não se trata do pensamento cognitivo, que parece cada vez mais claro constituir-se de linguagem, pois as palavras pensadas pertencem a uma língua particular. Não se trata, pois, de palavras que "soam" silenciosamente no espírito, muito menos das aparências infundidas na memória através dos sentidos, ou das aparições esculpidas pela mente racional, porque essas phantasiae e esses phantasmata não apenas são falsos, cópias e moldes forjados, mas também porque se imprimem e esculpem a partir de objetos de natureza inferior, natureza corpórea, mutável e corruptível. Ao contrário, trata-se de algo anterior a isso tudo, que equivocadamente tem sido confundido com o pensamento, mas que é também anterior ao próprio pensamento, pois se origina da eternidade da Palavra, que, por ser a Verdade imutável, nem pode ser o pensamento equívoco, muito menos a palavra limitada de alguma língua. E se ela se confunde com as próprias razões eternas, em virtude de sua semelhança com a natureza imutável, contudo não deve ser confundida com a língua universal subjacente a toda língua, como querem alguns, porque ela nasce fora do tempo, onde nenhuma língua é possível. É essa, portanto, a palavra do coração, uerbum cordis, palavra simples que só pode ser apreendida por uma inteligência igualmente simples, não complexa e fragmentada como a da mente cognitiva imersa nas cadeias do espaço-tempo; daí dizer-se anterior a toda linguagem.

\footnotetext{
${ }^{130}$ Trin. 15,10,19: Quisquis igitur potest intellegere uerbum, non solum antequam sonet, uerum etiam antequam sonorum eius imagines cogitatione uoluantur, hoc est enim quod ad nullam pertinet linguam, earum scilicet quae "linguae" appellantur "gentium", quarum nostra Latina est, quisquis, inquam, hoc intellegere potest, iam potest uidere per hoc speculum atque in hoc aenigmate aliquam uerbi illius similitudinem de quo dictum est: "In principio erat uerbum, et uerbum erat apud deum, et deus erat uerbum”.
} 
No entanto, se há um pensamento que se forma a partir da verdadeira ciência, quer dizer, a partir dessa palavra com a qual dizemos no coração, sem dúvida é um pensamento certo, pois quem fala algo verdadeiro (Trin. 15,10,19) fala aquilo de que tem conhecimento, não opinião, porque nascido da Verdade imutável, anterior a todo movimento incerto da mente cognitiva do homem, a todas as palavras equívocas de todas as línguas ${ }^{131}$. E se a Palavra eterna não pode ser dita nem pensada, aquele que deseja alcançar qualquer semelhança dela, adverte Agostinho (Trin. 15,11,20), embora através de muitas dessemelhanças, não deve buscá-la na palavra humana, quer dizer, nas línguas dos povos, pois mesmo quando essa palavra é apenas pensada no silêncio da mente (silentio cogitatur), ainda assim ela passível de ser pensada, quer dizer, em sua natureza articulada e determinada no tempo. Com efeito, versos podem ser entoados no espírito (carmina percurruntur animo), mesmo quando a boca do corpo se encontre calada (tacente ore corporis), pois tanto a quantidade das sílabas (numeri syllabarum) quanto os modos das cantilenas (modi cantilenarum), isto é, seus padrões rítmicos, ainda que sejam coisas corpóreas e pertencentes ao sentido da audição, através de suas imagens incorpóreas (incorporeas... imagines) se fazem presentes aos que pensam, sendo essas coisas revolvidas em silêncio na mente racional. Todavia isso tudo deve ser ultrapassado se se queira alcançar não apenas a Palavra eterna, mas também aquela palavra do coração, através de cuja semelhança, em enigma e espelho, a divina seja de algum modo vislumbrada. No entanto, nem mesmo quando formos semelhantes a Deus, quando o virmos tal como ele é (eum uidebimus sicuti est) (cf. 1Jo 3,2), nem mesmo aí nossa palavra será semelhante à dele, sentencia Agostinho $(15,16,26)$. De fato, mesmo que nossos pensamentos ali não sejam “volúveis" (uolubiles... cogitationes), transitando de um a outro conteúdo (ab aliis in alia euntes atque redeuntes), mesmo que seja único nosso conhecimento, apreendido numa visão simples e única (omnem scientiam nostram uno simul conspectu), ainda assim não se espera nenhuma igualdade com a Palavra que nem é dado compreender:

Quem, pois, dentre os homens é capaz dessa sabedoria, pela qual conhece Deus todas
as coisas, de modo que nem as coisas que se dizem pretéritas ali passem, nem as que
se dizem futuras sejam esperadas, como se não existissem, a fim de que venham a ser,
e tanto as coisas pretéritas como as futuras, juntamente com as presentes, sejam todas
elas presentes, e não sejam pensadas cada uma delas separadamente, e que ao pensar

${ }^{131}$ A Palavra de Deus a que o filósofo se refere (Trin. 15,11,20) nem é a palavra das Escrituras, comunicada pelos profetas e evangelistas, nem mesmo as palavras proferidas pela boca de Cristo, pelas quais se chega à fé (de quo iterum dictum est "igitur fides ex auditu auditus autem per uerbum Christi — cf. Rm 10,17). Pois essa palavra das Escrituras se diz "de Deus" apenas porque comunica uma doutrina divina, não humana (quia doctrina diuina traditur, non humana), contudo é disseminada nos sons das muitas e diversas línguas dos homens (in sonis multarum diuersarum linguarum), ao contrário da Palavra eterna. 
não se passe de umas às outras, mas numa única visão sejam todas as coisas presentes simultaneamente? ${ }^{132}$

\section{Confessiones: primeiras palavras}

Alguns bons anos antes do término do De trinitate, quando narrava os acontecimentos pregressos de sua caminhada espiritual em Confissões (397-401), que se converteram em algumas das mais belas páginas da literatura e do pensamento ocidentais, Agostinho descreve duas breves passagens cujo interesse ao longo da história tem sido relegado ao âmbito praticamente exclusivo da mística, nunca da linguagem. No entanto o que tem interessado aqueles que se puseram a pensar acerca deste último tema, especialmente mas não exclusivamente a partir das Investigações filosóficas de Wittgenstein, são as célebres passagens do livro inaugural (Conf. $1,6,8 ; 8,13)$, em que, em dois brevíssimos parágrafos construídos a partir de observações que fez do comportamento de outras crianças, narra como teria aprendido manifestar suas vontades por meio dos signos. Por isso, embora essas curtas passagens, quando consideradas isoladamente, não façam justiça nem aos propósitos do livro de que foram extraídas, muito menos às demais passagens da obra do filósofo em que o tema da linguagem se faz objeto de alguma inquirição, recomenda a prudência que se as investigue, posto que sucintamente, antes do derradeiro obséquio que se há de demandar do leitor destas páginas, ao convidá-lo a voltar - separa as outras duas passagens que têm apaixonado místicos desde priscas eras, dentre as quais destaca-se o chamado "êxtase de Óstia", no livro nono da referida obra.

Pois bem, no $32^{\circ}$ parágrafo de suas Investigações filosóficas, ao referir-se àquilo que entendia como sendo o processo de aquisição da linguagem defendido por Agostinho, Wittgenstein diz que o autor das Confissões imaginava a criança como se fosse um viajante que chegasse a uma terra estrangeira para ali aprender a língua praticada, porém já possuindo sua própria língua, "como se a criança já pudesse pensar, mas ainda não falar" (als könne das Kind schon denken, nur noch nicht sprechen); "pensar", que, neste caso, diz o filósofo austríaco, significaria para a criança algo como falar consigo mesma (und "denken" hieße hier etwas, wie: zu sich selber reden). Isso o autor das Investigações diz a partir de uma leitura literal do texto, como se se tratasse de memórias ditadas por um recém-nascido, não de um relato poético de um homem maduro, embebido em piedoso e tocante lirismo, para finalidade bem outra que a descrição

132 Trin. 15,7,13: Quis ergo hominum potest istam sapientiam, qua nouit deus omnia, ita ut nec ea quae dicuntur praeterita ibi praetereant, nec ea quae dicuntur futura, quasi desint, exspectentur ut ueniant, sed et praeterita et futura cum praesentibus sint cuncta praesentia, nec singula cogitentur et ab aliis ad alia cogitando transeatur, sed in uno conspecto simul praesto sint uniuersa? 
fenomênica do processo de aquisição da linguagem. Porém, antes de prosseguir com os comentários, convém voltar-se às palavras em questão do próprio autor do relato "autobiográfico":

[Conf. 1,6,8] Daí também comecei a rir, primeiro dormindo, depois acordado. Pois foi isto que me foi revelado a meu respeito, e eu acreditei, porque assim é que vemos as outras crianças. De fato, eu não me lembro dessas minhas [experiências]. E eis que paulatinamente sentia onde estava e queria mostrar-lhes [aos adultos] minhas vontades, para que por meio deles elas pudessem ser satisfeitas, e não podia, porque elas estavam no interior, porém eles, no exterior, e nem por algum sentido seu eles eram capazes de penetrar a minha alma. E assim projetava os membros e minha voz, signos semelhantes às minhas vontades, os poucos que podia, do modo como podia, pois eles não tinham muita verossimilhança. E quando não era obedecido, seja por não ter sido compreendido, seja para que [algo] não me prejudicasse, me indignava com os adultos que não se submetiam [a mim] e com as pessoas de condição livre que não [me] serviam, e deles me vingava, chorando. Aprendi que são assim as crianças, as quais pude conhecer; e que eu [também] tenha sido assim, [isso] mais me indicaram as próprias [crianças], sem o saber, do que aqueles que me nutriram, sabendo. ${ }^{133}$

O primeiro aspecto que deve ser ressaltado, antes dos demais, é que Agostinho admite não lembrar de seus primeiros anos, como sói ocorrer, naturalmente, com todas as pessoas. Do que se depreende logo tratar-se de uma narrativa de caráter literário, ainda que tenha sido construída a partir da observação do comportamento de algumas crianças, as quais, contudo, ele se deu o trabalho de estudar apenas muito tempo depois de sua própria infância, quando pôs-se a escrever - poeticamente - sobre o tema. Destarte, quando diz que "sentia paulatinamente onde estava", o faz de modo ficcional, deduzindo ter sido assim, embora nada lembrasse de fato, como confessa antes: "eu não me lembro" (ista mea non memini). No entanto o que interessa sobretudo nesta passagem é sua observação, tanto mais perspicaz quanto acurada, acerca do esforço das crianças para fazer com que suas vontades, de que nem mesmo tinham ciência, fossem conhecidas; crianças que eram absolutamente incapazes de cogitar o que ele agora deduzia, no tempo presente da narrativa, acerca de seu comportamento pregresso. E se é assim, nada conveniente imaginar que sua proposta fosse a de um retrato rigoroso da mentalidade infantil, como se evidencia pelo contexto altamente lírico da obra e pelos propósitos eminentemente espirituais pretendidos, que, como aponta Burnyeat (1987, p. 4), visavam destacar acima de tudo a Graça divina no processo de aprendizagem: "não é nem uma simples lembrança, nem uma hipótese conjectural do psicólogo empirista, mas a contribuição altamente autoconsciente

\footnotetext{
${ }^{133}$ Conf. 1,6,8: Post et ridere coepi, dormiens primo, deinde uigilans. hoc enim de me mihi indicatum est et credidi, quoniam sic uidemus alios infantes. nam ista mea non memini. et ecce paulatim sentiebam ubi essem et uoluntates meas uolebam ostendere eis, per quos implerentur, et non poteram, quia illae intus erant, foris autem illi, nec ullo suo sensu ualebant introire in animam meam. itaque iactabam membra et uoces meas, signa similia uoluntatibus meis, pauca quae poteram, qualia poteram, non enim erant uerisimilia. et cum mihi non obtemperabatur uel non intellecto uel ne obesset, indignabar non subditis maioribus et liberis non seruientibus et me de illis flendo uindicabam. . tales esse infantes didici, quos discere potui; et me talem fuisse, magis mihi ipsi indicauerunt nescientes, quam scientes nutritores mei.
} 
para a compreensão teológica" ${ }^{" 134}$, porque seu objetivo primeiro não era dar conta do fenômeno da linguagem, mas ressaltar a "responsabilidade" divina na educação que a mente dá a si mesma. E isso resta perfeitamente cristalino já na passagem subsequente, onde diz que só se deu conta de como aprendeu a falar tempos mais tarde. Portanto assumir que a passagem tenha caráter empírico, e daí científico, constitui, no mínimo, um exagero. O 13. parágrafo, na sequência do livro inaugural, talvez ilumine ainda mais a questão:

[...] Pois eu não era [mais] uma criancinha que não falava, mas já era um menino falante. E disto eu me lembro; e de onde havia aprendido a falar, depois é que percebi. Pois os adultos não me ensinavam mostrando-me as palavras de acordo com uma determinada ordem de [alguma] doutrina, como pouco depois [fariam, ao ensinar-me] as [primeiras] letras, mas eu mesmo, com a mente que tu me deste, meu Deus, com gemidos e vozes variados e com variados movimentos dos membros queria comunicar os sentimentos do meu coração, para que se obedecesse à minha vontade, [mas] nem era capaz de [comunicar] todas as coisas que queria, nem a todos os que queria [fazêlo]... ${ }^{135}$

Imaginar que a criança, antes de ser alfabetizada, é que fazia essas perguntas que o pensador maduro elabora aqui, numa prosa altamente poética, direcionada para Deus em tom inusitadamente confessional, é o mesmo que imaginar que o relato autobiográfico da atriz francesa, surda de nascença, Emanuelle de Laborit (2003, pp. 22-23), escrito com a colaboração de Marie-Thérèse Cuny, retrata ipsis litteris o que a criança era capaz de pensar, quando não havia ainda nem mesmo aprendido a linguagem de sinais:

[...] eu aprendi esta língua [de sinais] apenas aos sete anos. Antes, eu era por certo um pouco com uma "estúpida", uma selvagem. É insano. Como é que pude me construir? Como é que pude compreender? Como é que fazia para chamar as pessoas? Como é que fazia para pedir alguma coisa? Eu me vejo fazendo mímicas com frequência. Eu pensava? Por certo. Mas em quê? Na minha fúria de me comunicar, absolutamente! [...] E eu puxava minha mãe pela manga, pelo vestido; eu lhe mostrava os objetos, um monte de coisas; ela compreendia, ela respondia. [...] Até a idade de sete anos não havia palavras nem frases na minha cabeça, apenas imagens. Quando eu puxava minha mãe (isto significava chamá-la), para lhe dizer alguma coisa, eu não queria que ela olhasse para outro lugar; era para mim, para minha face e nada além que ela deveria olhar. Eu me lembro disso; portanto havia um pensamento, pois eu "pensava" a comunicação; eu a desejava. ${ }^{136}$

\footnotetext{
${ }^{134}$ Cf. Conf. 1,6,7: “[...] eu mesmo não me lembro. Sustentaram-me, pois, as consolações do leite humano, [mas] não [era] a minha mãe ou minhas amas que enchiam seus seios [de leite], mas tu é que através delas me davas o alimento da infância..." (non ego memini. exceperunt ergo me consolationes lactis humani, nec mater mea uel nutrices meae sibi ubera implebant, sed tu mihi per eas dabas alimentum infantiae...).

${ }^{135}$ Conf. 1,8,13: [...] non enim eram infans, qui non farer, sed iam puer loquens eram. et memini hoc, et unde loqui didiceram, post aduerti. non enim docebant me maiores homines praebentes mihi uerba certo aliquo ordine doctrinae sicut paulo post litteras, sed ego ipse mente, quam dedisti mihi, deus meus, cum gemitibus et uocibus uariis et uariis membrorum motibus edere uellem sensa cordis mei, ut uoluntati pareretur, nec ualerem quae uolebam omnia nec quibus uolebam omnibus...

${ }^{136}$ A tradução é de responsabilidade deste autor.
} 
Havia um pensamento, pois "eu pensava" — puisque je "pensais" — , relata Laborit, e disso ela afirma estar lembrada: Je me souviens de ça, il y avait donc une pensée. Mas sem dúvida não era articulado do modo como aparece em seu relato, escrito anos depois com a imprescindível colaboração alheia. Portanto, ainda que tenham sido pertinentes as objeções de Wittgenstein (I.F. §§ 342-344) ao relato de William James, questionando a natureza linguística das reminiscências de um surdo, o Sr. Ballard, que asseverava ter pensado em Deus mesmo antes de que pudesse falar (noch ehe er sprechen konnte), contudo isso não exclui a possiblidade de algum pensamento de natureza cognitiva. E de fato, de acordo com Jean Piaget, por exemplo, como explica Ana Paula Santana (2007, p. 205), a linguagem estava apenas parcialmente relacionada à cognição, sendo distintas suas origens, visto que o desenvolvimento da linguagem dar-se-ia pari passu com o da chamada "função simbólica", a qual se considerava dependente de processos cognitivos previamente adquiridos. Assim, para o pensador suíço, aponta Santana (id. ibid.), há uma etapa inicial "sensório-motora", que se caracteriza pela ação, a partir da qual a criança evolui para uma etapa "pré-operacional”, na qual contribuem para a aquisição da linguagem certos "esquemas mentais" previamente adquiridos. Todavia, se é indisputável que a linguagem favorece o surgimento e posterior desenvolvimento do pensamento racional, o que também admitia Piaget, visto que é através dela que a criança se capacita a desprender-se do presente e do "espaço próximo" e "evocar situações passadas", contudo para o pesquisador suíço “o pensamento precede a linguagem”, que dará conta, apenas depois, de transformá-lo profundamente. Portanto, embora seja importante para o pensamento por incrementar-lhe muito as possibilidades de compreensão, a linguagem não era determinante, ao menos para Piaget, assevera Santana (id. ibid.), "porque a origem do pensamento lógico não se encontra na linguagem, mas nas ações sensoriais da criança"; numa palavra, a linguagem "não está diretamente relacionada com o desenvolvimento da inteligência", como ele pôde depreender do estudo do comportamento das crianças, cujo conhecimento de mundo não se reflete na linguagem. Demais, acresce ainda Machado ${ }^{137}$ (apud SANTANA, ibid. p. 206), a linguagem verbalizada não é a única forma de comunicar pensamentos, uma vez que ele também crê, na esteira do próprio Piaget, que a "construção" da inteligência lhe é antecedente. No caso específico dos surdos, tema do estudo de Ana Paula Santana, de acordo coma tese da anterioridade do pensamento em relação à linguagem, o atraso no seu desenvolvimento cognitivo não seria decorrência de sua "ausência de linguagem", conclui a autora (ibid.), mas da "falta de experiências comunicativas da criança”, ao menos nos estágios iniciais.

${ }^{137}$ Linguagem e pensamento da criança. In: Revista espaço, 1996, pp. 21-23. 
Na sequência do parágrafo supracitado das Confissões, Agostinho rapidamente relata não como se lembra de ter aprendido a linguagem, mas como, no tempo da narrativa, infere teria sido feito a partir do que observou depois em outras crianças, de modo intensamente poético, faz-se mister ter sempre em mente:

[...] quando os próprios [adultos] chamavam alguma coisa e quando de acordo com aquela voz moviam seu corpo em direção a alguma coisa, eu via e retinha [no espírito] que aquela coisa era chamada por eles [com este] som que faziam, quando queriam mostrá-la. Porém isto que eles queriam se fazia evidente a partir do movimento de seu corpo, como se por meio de palavras naturais de todos os povos, as quais se fazem pelo semblante e pelo movimento dos olhos e dos restantes membros [...] Assim eu ia pouco a pouco deduzindo de que coisas eram signos as palavras posicionadas em várias sentenças, [cada uma] em seu lugar, [depois de] ouvidas repetidas vezes, e agora enunciava minhas vontades através da boca, que havia sido adestrada [no proferimento] desses signos. E assim na companhia destes [adultos], entre os quais estava, comuniquei os signos para enunciar as minhas vontades... ${ }^{138}$

Dizer que ia a pouco e pouco coligindo as palavras sintaticamente ordenadas em sentenças frequentemente ouvidas, as quais eram depois armazenadas na memória, ciente de que coisa cada palavra era signo, sendo apenas uma criança, não pode ser interpretado senão no registro poético-confessional em que foi concebida a obra, fora do qual seria deformador do pensamento do autor, como dito e reiterado. Não é a criança que está narrando, nem se trata de suas memórias infantis, como ficou claro, mas de prosa de natureza poético-filosófica com que pretende confessar a Deus suas misericórdias, dentre as quais, depois da própria vida e do leite materno, a capacidade de falar, que, como tudo o mais de que poderia vangloriar-se o homem, é dom de Deus, pois nada tem ele que não tenha recebido de seu Criador ${ }^{139}$. Demais, considerar que o pensamento de Agostinho acerca da linguagem, se se pode dizer de fato que ele tenha pensado sistematicamente acerca do tema e não apenas perifericamente, enfim, que possa ser representado por esses dois breves parágrafos, como dito, desconsiderando o lirismo da passagem para torná-la resultado de pesquisas de campo de um psicólogo empirista, no dizer de Burnyeat, em detrimento do restante de sua obra, de modo nenhum se justifica. Todavia, como dito no início, a passagem que interessa aos propósitos desta investigação, que agora demanda urgentemente um termo, embora pareça nada ter que ver com a linguagem, e sim com a mística, permite uma

\footnotetext{
${ }^{138}$ Conf. 1,8,13: [...] cum ipsi appellabant rem aliquam et cum secundum eam uocem corpus ad aliquid mouebant, uidebam et tenebam hoc ab eis uocari rem illam, quod sonabant, cum eam uellent ostendere. hoc autem eos uelle ex motu corporis aperiebatur tamquam uerbis naturalibus omnium gentium, quae fiunt uultu et nutu oculorum ceterorumque membrorum [...]. ita uerba in uariis sententiis locis suis posita et crebro audita quarum rerum signa essent paulatim colligebam measque iam uoluntates edomito in eis signis ore per haec enuntiabam. sic cum his, inter quos eram, uoluntatum enuntiandarum signa communicaui...

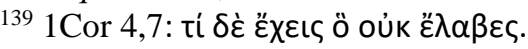


visão sinótica dos diversos sentidos em que a noção de palavra se permite compreender na obra do pensador. A elas, pois.

\section{No silêncio da Palavra}

Um pouco antes, no sétimo dos treze livros das Confissões $(7,10,16)$, Agostinho de certo modo preludiava, ainda que indiretamente, a célebre passagem do êxtase de Óstia, que iria narrar no livro nono, ao descrever exercício análogo ao que relataria ter vivenciado algum tempo depois, na companhia de sua mãe, Mônica (Conf. 9,10,23-25) ${ }^{140}$. Naquele momento da narrativa, sentindo-se admoestado pelos livros dos platônicos que havia frequentado a voltar-se para dentro de si mesmo, Agostinho diz que penetrou o seu íntimo, onde viu, porém não com os olhos do corpo, mas com o olho da alma (oculo animae), acima do próprio olho da alma (supra oculum), acima de sua própria mente (supra mentem), uma Luz imutável (lucem incommutabilem). Essa Luz não tinha nada que ver com a luz corpórea que se percebe pelos olhos, porque, a bem dizer, não estava acima da mente, como o óleo se mantém acima da água, mas se dizia "superior" porque tudo que existe foi por ela criado, inclusive o homem, que agora se punha a contemplá-la (superior quia ipsa fecit me); ela que é Verdade, Amor, Eternidade. Isso, portanto, é também o que filho e mãe lograram vislumbrar, numa rapida cogitatio, quando em Óstia, às margens do Tibre, aguardavam para retornar à sua África natal, por volta do final de 388 ou início de 389.

Conversavam a sós, relata Agostinho (§23), deixando para trás as coisas passadas, voltados às que estão adiante, buscando indagar, sob os auspícios da própria Verdade, quer dizer, depois de elevadas a Deus as devidas deprecações, de que qualidade seria a vida futura dos santos na eternidade (qualis futura esset uita aeterna sanctorum). Ansiavam, segue o rétor, com a boca do coração (ore cordis) a corrente superna da Fonte divina, para que dali, de acordo com sua capacidade e de algum modo aspergidos por essa Fonte de Vida, pudessem "cogitar" algo de tamanha grandeza. Portanto para a excelsitude deste destino (ad finem), a jucundidade da vida eterna, é que a conversa (sermo) era conduzida, fim infinitamente superior a qualquer prazer (delectatio) que os sentidos da carne pudessem proporcionar ( $\$ 24)$, ao qual se elevavam cada vez com afeto mais ardente, percorrendo de um em um os degraus da criação, desde as criaturas corporais todas (cuncta corporalia), ascendendo até o próprio céu, de onde fazem

${ }^{140}$ Bernard McGinn (1991, pp. 232-233) considera que se trata, neste caso, de uma ou mais (Conf. 7,10,16-17; $17,23 ; 20,26)$ experiências místicas havidas em Milão, então sob a influência do neoplatonismo (especificamente Plotino e Porfírio), de que ali recentemente tomara conhecimento. 
brilhar sua luz o Sol, a Lua e as estrelas, sobre a superfície da terra, daí ascendendo ainda mais, porém não para o alto, e sim mais para dentro de si mesmos, pensando e falando (cogitando et loquendo), ao admirar-se da obra de Deus, depois do que chegam às próprias mentes, as quais também transcendem, para atingir então a região da abundância indefectível, onde Deus apascenta Israel eternamente com o repasto da Verdade (ueritate pabulo), ali onde a Vida é Sabedoria (et ibi uita sapientia), pela qual se fazem todas essas coisas, as quais foram (quae fuerunt), as quais serão (quae futura), porém ela própria não é feita, mas é assim (sed sic est), como foi (ut fuit) e como será sempre (et sic erit semper), pois ter sido e haver de ser não está nela, apenas o ser (solum esse), visto que é eterna. Enquanto falavam, ansiando pela Vida eterna, atingiramna, posto que modicamente, num como que icto que tomou todo o coração, e depois de suspirar profundamente, deixaram ali, ligadas, as primícias do espírito, para retornar em seguida ao estrépito dos sons produzidos pela boca, onde a palavra não apenas começa, mas também termina, distante da Palavra eterna, que permanece em si mesma renovando todas as coisas, embora ela mesma jamais envelheça.

Durante essa conversa, narra Agostinho (\$25), mãe e filho diziam-se ${ }^{141}$ que se a alguém silenciasse o tumulto da carne (si cui sileat tumultus carnis), se lhe silenciassem as aparências da terra, das águas e do ar (sileant phantasiae terrae et aquarum et aeris), se lhe silenciassem também os céus (sileant et poli), e se a própria alma lhe silenciasse (et ipsa anima sileat) e ultrapasse a si mesma (et transeat se), não se pensando mais a si mesma (non se cogitando), ao silenciar os próprios sonhos (sileant somnia), as revelações imaginárias (et imaginariae reuelationes), ao silenciar toda língua (omnis lingua) e também todo signo (et omne signum), e os movimentos todos que, sendo passageiros, possam ocorrer em seu interior, enfim, se a mente lhe silenciasse por completo (si cui sileat omnino), não apenas ouviria as próprias criaturas clamarem que não se fizeram a si mesmas (non ipsa nos fecimus), mas também que foram criadas por aquele que permanece eternamente, Deus. E se, indo além, esses mesmos ditos interiores (his dictis) que se fizeram ecoar através das criaturas, no silêncio absoluto da alma, se eles também se calassem por completo, depois de terem erguido o ouvido da alma até seu Criador, de modo que nenhuma criatura mais falasse, mas ele próprio, porém não através delas, ele apenas (et loquatur ipse solus), por si mesmo (sed per se ipsum), para que sua própria Palavra fosse ouvida (ut audiamus uerbum eius), mas não através de uma língua de carne (non per

\footnotetext{
${ }^{141}$ McGinn (ibid., p. 234) entende que a passagem contém duas descrições paralelas da experiência mística: uma em que narra diretamente os eventos transcorridos; outra em que resume e tenta explicar o teor da conversa que teve com sua mãe, conversa que ele parece suspeitar ter sido um monólogo. Essa distinção, contudo, importa pouco para os propósitos desta análise.
} 
linguam carnis), nem pela voz de um anjo (nеque per uocem angeli), nem pelo estrondo de uma nuvem (nec per sonitus nubis), nem através do enigma (nec per aenigma) de um símile (similitudinis), mas ele próprio (sed ipsum), o qual nestas coisas todas que criou é amado (quem in his amamus), numa palavra, se a ele próprio se pudesse ouvir, por meio de um "rápido pensamento" (rapida cogitatione), seria aí alcançada então a eterna Sabedoria, que permanece acima de todas as coisas (super omnia manentem). E se esse pensamento pudesse prolongar-se, mantendo-se subtraídas as visões todas da alma (subtrahantur aliae uisiones), e apenas esta única "visão" a arrebatasse (et haec una rapiat) e a absorvesse (et absorbeat), seu expectador seria assentado de vez na alegria interior (interiora gaudia) em que se constitui a vida eterna. E foi esse, resume Agostinho, o "momento de inteligência" (momentum intelligentiae), se assim se permite dizê-lo, momento por eles vivenciado, a alegria eterna diante da Face de Deus, que se espera seja fruída depois das mudanças operadas na natureza humana, na ressurreição.

Se a Palavra eterna de que nasce a palavra do coração, como visto anteriormente, só se atinge no mais completo silêncio de todas as demais palavras, quer dos signos sonoros, quer dos signos mentais, quer das aparências suscitadas pelos sentidos corpóreos, quer das aparições modeladas, armazenados todos na memória, quer da própria mente racional, que deve "des-

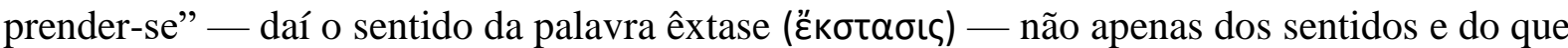
lhe advém através deles, mas também de si mesma, enfim, se para atingir essa Palavra, que é Deus, faz-se mister o mais completo "silêncio" de toda e qualquer palavra, compreende-se daí sua natureza supralinguística, consequentemente inefável e inapreensível, ao menos por meio da mente cognitiva, cuja natureza é mutável e temporal. De fato, a Palavra eterna está fora do tempo, por isso não pode ser apreendida por nada que seja temporal, como as palavras que têm começo e fim.

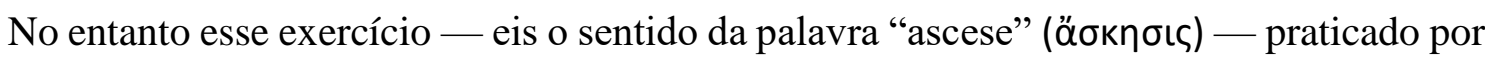
Agostinho e Mônica, de modo aparentemente paradoxal, dá-se por meio da fala (locutio) e do pensamento (cogitatio), cuja matéria-prima é a palavra, quer sonora, quer silenciosa, porém sempre articulada no tempo. Diz-se de modo aparentemente paradoxal porque, assim com a teologia negativa, esta prática ascética se utiliza de palavras em sua contemplação de Deus e de sua obra, ciente de que assim o faz com absoluta impropriedade. Porém ao contrário da apofática, a teologia dita catafática não se permite deter pela negação, mas querendo ascender sempre mais, diz e pensa muitas e variadas palavras, contudo apenas até o limite da linguagem. E assim o é. E não o é de modo distinto do que dirá, nada revolucionariamente, o próprio Wittgenstein, séculos depois, ao dizer que os limites do pensamento encontram-se nos limites da linguagem. 
Vê-se bem por meio desse exercício ascético que a linguagem chega até o limite supremo estabelecido para ela, que não é sonoro, mas mental. De fato, o último passo antes de ouvir a Palavra eterna constitui-se das palavras silenciosas das criaturas, que dizem: "Não fomos nós que nos fizemos, mas foi ele, foi ele quem nos fez!" Ora, como dizem, se não o fazem com palavras? Porém não são palavras audíveis, mas silenciosas, palavras que se ouvem nos limites da razão, nos limites extremos do pensamento cognitivo, além do que só há silêncio, porque ali, onde nada foi ou será, não pode haver palavras que têm começo, meio ou fim. Portanto naquela região da indefectível abundância (regionem ubertatis indeficientis), onde a Vida é Sabedoria, ou seja, onde a Vida é Inteligência pura, chega-se ao perfeito desprendimento, pois ali nada foi nem será, sendo apenas um presente sem fim. Eis o limite do pensamento cognitivo, onde a linguagem encontra abismo intransponível. Ora, não é a razão que penetra essa a região da Plenitude, mas o espírito, pois ali só há Presença, ou "visão" (uisio), no dizer trinitário de Agostinho. Mas se o Fim é silêncio, por que as palavras, quer dizer, qual seu papel nessa ascese? Na verdade trata-se de um exercício também apofático, pois o silêncio, neste caso, implica a negação de todas as modalidades da palavra. Com efeito, primeiro tem-se um silêncio dos sentidos (1.1 sileat tumultus carnis; 1.2 sileant phantasiae: terrae, aquarum, aeris; 1.3 sileant et poli); depois o silêncio das imagens mentais (2.1 sileat ipsa anima et transeat se; 2.2 sileant cogitationes: non se cogitando; 2.3 sileant somnia; 2.4 sileant imaginariae reuelationes); em terceiro o silêncio dos signos linguísticos (3.1 [sileat] omnis lingua; 3.2 [sileat] omne signum), ao qual se associa o silêncio dos significados (4.1 si cui sileat omnino quidquid fit [a signis] transeundo), quer dizer, nega-se também tudo aquilo que se faz quando o signo transita, vai além, significa, ou seja, que silenciem as coisas que os signos significam, as coisas para as quais eles apontam. Esse "silenciar", aqui, significa "sumir" da mente. Portanto, depois das imagens mentais, silenciam-se, apagam-se as palavras (os signos mentais), e com elas também aquilo que significam. Que silencie assim toda a alma, tudo o que que nela constitui linguagem! Ora, se não se pensasse em linguagem, como se deveria interpretar esse silenciar da linguagem, se Agostinho não está falando das palavras que soam, mas das que se fazem ouvir apenas na mente?

No entanto há ainda um quinto silenciar, um último movimento apofático, a negação de um tipo estranho de palavra, pois sucede ao último movimento da mente cognitiva, que se dá quando se ouve, com o ouvido do coração, o que dizem as criaturas, que elas não são Deus, mas que foram feitas por ele. Não dizem com palavras sonoras, e todavia dizem (dicunt omnia). Mas como dizem, senão com palavras? Trata-se sem dúvida de um silêncio inesperado, da palavra 
do coração, pois ela refere aquela Verdade imutável que clama toda criação: a ciência (scientia) de que há um Criador! Ela também deve calar, como tudo o que não é Deus, pois, embora nasça da Palavra eterna, não é ela. Assim, depois do último silencio, do silêncio da palavra do coração, tem-se a Palavra de Deus: loquatur ipse solus. Deus fala, mas não através de nenhuma criatura, e sim ele mesmo, que "ouçamos" diretamente sua Palavra. A Palavra de Deus é ouvida sem intermediários, mas não pela língua da carne, nem pelas vozes angélicas, nem pelos estrondos das nuvens, nem pelos enigmas dos símiles, pois a Voz de Deus prescinde de tudo o que não é ele. Contudo nesse apagar das luzes do pensamento cognitivo, nesse eclipse da razão, não resta o ser humano sem inteligência, muito ao contrário, ao penetrar os átrios da suprema Sabedoria, vivencia a Presença, está diante da Inteligência pura do Espírito, que tudo sabe, pois tudo apenas é; e o sabe agora, pois não há senão o eterno agora. Há nessa Presença, posto que supracognitiva, uma comunhão total e sem fim com a Sabedoria divina, criadora de todas as coisas, de modo nenhum uma obliteração da inteligência.

\section{Palavras finais}

A proposta deste artigo era investigar se a relação entre linguagem e pensamento para Agostinho era uma de irremediável dissociação, como se costuma dizer, onde os signos sonoros seriam articulados, porém os silenciosos, algo distinto, mais próximo de uma como que razão universal e anterior à toda linguagem, ou se de algum modo seria ainda possível fazer incidir alguma luz sobre a questão, oferecendo subsídios para uma nova abordagem. Para tanto empreendeu-se uma rápida leitura de passagens selecionadas de alguns de seus escritos, nos quais as palavras se faziam de algum modo objeto de inquirição, seja em si mesmas, seja para propósito ulterior. E em todos eles o que se tornou perceptível, para muito além da ingenuidade préfilosófica que lhes tem sido atribuída, ao menos desde Wittgenstein, foi a complexidade do tratamento dado à questão da linguagem, nada obstante ela jamais ter feito parte do rol das suas principais preocupações intelectuais. Num primeiro passo levantou-se a suspeita de que considerar inconclusivas as passagens do Teeteto e do Sofista, com respeito à natureza da articulação no pensamento, parece, no mínimo, um tanto apressado. Em seguida propugnou-se por demonstrar que já no De dialectica, ainda que se tratasse de um projeto mal começado, parece haver uma promissora proximidade entre o dicibile, que se concebe no espírito ex uerbo, e a palavra como voz articulada, a qual é falada por um falante e ouvida por um ouvinte. Em seguida, com o De magistro, sugeriu-se que as palavras de natureza articulada também constituem matéria- 
prima da mente racional, nada obstante restar claro, a partir da proposta filosófica do autor, da qual a obra não deve ser destacada, que o signo é de natureza inferior à coisa significada, visto que, de acordo com a doutrina que ali se delineia, os fins devem ser preferidos aos meios. No De doctrina christiana, por sua vez, onde a superioridade dos fins se transubstancia na célebre distinção entre uti e frui, usar e fruir, Agostinho deixa claro que os signos, seja de que natureza forem, devem ser apenas usados, jamais fruídos, porque só a Palavra eterna deve ser amada em si mesma, natureza imutável de que as palavras humanas, imersas na temporalidade, quer exteriores, quer interiores, não participam; o que, contudo, não significa dizer que as palavras estejam destituídas de considerável valor. Depois, ainda na mesma obra, ao comparar as palavras interiores à Palavra eterna para tentar justificar o mistério da Encarnação, retomando uma tradição que remonta a Justino, Agostinho permite apenas supor uma proximidade entre a palavra gestada no coração e as palavras proferidas pela boca. Na sequência, no terceiro parágrafo de uma homilia proferida em Cartago, o rétor aprofunda a noção de palavra interior, que, não sendo de língua nenhuma, parece afastar-se irremediavelmente da linguagem, ainda que o signo linguístico deus, utilizado como ilustração pelo rétor, seja absolutamente inapropriado para os fins aqui propostos. Nos dois escritos subsequentes, trechos de duas homilias constantes dos $C X X I V$ Tractatus acerca do Evangelho de João, a questão parece caminhar no sentido do esclarecimento, quando se percebe que essa palavra do coração nem é a Palavra eterna, tampouco o pensamento articulado, mas algo distinto de ambos, uma vez que a Palavra de Deus é o próprio Deus, ao passo que a palavra do coração apenas procede dele ( $d e$ deo), fazendo brilhar na mente a Luz da Verdade imutável, como as razões eternas a que a mente racional recorre para a emissão dos juízos estéticos, por exemplo, conforme se percebeu na sequência pela leitura dos excertos do De trinitate; palavra do coração, que, embora permita vislumbrar a eterna Palavra, o faz apenas em enigma através de um espelho, porque ela é inefável. E é também como espelho, porém agora da mente racional, que a palavra do coração talvez melhor se compreenda, pois, ao espelhar a Luz da Verdade, conecta e ordena os conteúdos da mente cognitiva; e ainda que se diga anterior à toda linguagem, contudo é por meio dela que se manifesta na mente. Assim, se sua natureza se não se limita à do signo linguístico, também não a exclui completamente, porque não se encontra de todo dissociada de sua natureza cognitiva, ainda que não deva ser confundida com o pensamento cognitivo, menos ainda com a linguagem articulada, mas apenas como uma palavra mediadora, se se permite dizê-lo, uma palavra que liga o eterno ao temporal, o céu à terra, o Intelecto divino à sua imagem e semelhança no homem, a inteligência. Por fím, a partir de uma rápida leitura da célebre passagem do nono livro das Confessiones, em que 
Agostinho e Mônica se entregam ao exercício contemplativo, chegando ao desprendimento supremo, no silêncio absoluto de todas as palavras, chega-se ao limite não apenas da linguagem, mas do pensamento cognitivo, permitindo entrever, de modo inequívoco, e desfazendo quaisquer dúvidas causadas pela polissemia do termo latino uerbum, mas também pela discrepância dos gêneros a partir dos quais se costuma recortar trechos das obras do filósofo, enfim, permitindo entrever não apenas o caráter linguístico, e consequentemente articulado, do pensamento cognitivo, no tempo, mas também a verdadeira natureza da palavra do coração, que, não pertencendo a língua nenhuma, tantas leituras equivocadas tem causado.

Portanto, o que se permite concluir, nada obstante o peso e o consequente risco que esse verbo implica, é que todas as palavras, seja a falada, seja a excogitada, seja até mesmo a do coração, ainda que em sentido mediato, com exceção apenas da Palavra cuja natureza eterna é inefável, todas elas, enfim, implicam movimentos e articulações não apenas cognitivos, mas necessariamente linguísticos, se se permite dizê-lo, sem o que nenhuma delas poderia nem ser compreendida no conjunto da obra do autor, muito menos silenciada, como se depreende do exercício extático narrado nas belas páginas de Confessiones. Daí também todas elas se dizerem uerba, o que não se faz pela pobreza semântica da língua latina, mas porque partilham da mesma natureza articulada. É possível dizer, por fim, que as estruturas mínimas percebidas nos modelos linguísticos aparecem igualmente nos modelos cognitivos, mesmo que padeçam, se se queira realmente insistir nisso, contudo de modo bastante inapropriado, da abordagem sistemática que hoje se busca retroprojetar nelas.

\section{BIBLIOGRAFIA}

ALLEN, James. The Stoics on the Origin of Language and the Foundations of Etymology. In: FREDE, Dorothea; INWOOD, Brad (Editors). Language and Learning. Philosophy of Language in the Hellenistic Age. Cambridge: CUP, 2008, pp. 14-35.

ARAÚJO, Inês Lacerda. Do signo ao discurso. Introdução à filosofia da linguagem. São Paulo: Parábola, 2004.

ARROJO, Rosemary (Org.). O signo desconstruído. Implicações para a tradução, a leitura e o ensino. $2 .^{\mathrm{a}} \mathrm{ed}$. Campinas, SP: Pontes Editores, 2003.

AUGUSTIN. De magistro. (Traduction, introduction et notes de F. J. Thonnard.) 2me éd. Paris: Desclée de Brouwer et cie., 1952. (Bibliothèque Augustinienne - Euvres de Saint Augustin. Dialogues philosophiques, VI: De l'ame a Dieu, III.)

La Trinité. (Traduction et notes par M. Mellet, Th. Camelot; Introduction par E. Hendrickx; avantpropos par G. Madec.) Paris: Institut d'Études Augustiniennes, 1997. (Bibliothèque Augustinienne Euvres de Saint Augustin, n. 15-16. Vol. I : Livres I-VII; Vol. II: Livres IX-XV.) 
Les confessions. (Introduction et Notes par Aimé Solignac. Traduction de E. Tréhorel et G. Bouissou.) $2^{\mathrm{e}}$ éd. Paris: Institut d'Études Augustiniennes, 1998. (Bibliothèque Augustinienne - Euvres de Saint Augustin, n. 13-14. Vol. I : Livres I-VII ; Vol. II : Livres VIII-XIII.)

AUGUSTINE. Augustine on Romans. Propositions from the Epistle to the Romans; Unfinished Commentary on the Epistle to the Romans. (Text and Translation by Paula Fredriksen Landes.) Chico, California: Scholars Press, 1982. (Texts \& Translations, 23; Early Christian Literature Series, 6.)

. De dialectica. (Translated with introduction and notes by B. Darrell Jackson; edited by Jan Pinborg.) Dordrecht, Holland; Boston, USA: Reidel P. Co., 1975.

De doctrina christiana. (Edited and translated by R. P. H. Green.) Oxford: OUP, 2004.

AUGUSTINI, Aurelius. In Iohannis euangelium tractatus CXXIV. Turnholti: Brepols, 1954. (CORPVS CHRISTIANORVM. Series Latina XXXVI.)

AUROUX, Sylvain. La philosophie du language. 2e éd. Paris: PUF, 2013.

La question de l'origine des langues. Paris: PUF, 2007.

BENVENISTE, Émile. Problèmes de linguistique générale. Vol. I. Paris: Gallimard, 1966, pp. 63-74, "Categories de pensée et categories de langue".

BURNYEAT, M. F. The Inaugural Address: Wittgenstein and Augustine De magistro. In: Proceedings of the Aristotelian Society, Supplementary Volumes. Vol. 61 (1987), pp. 1-24. Wiley-Blackwell Publishing; Stable URL: http://www.jstor.org/stable/4106832.

CARROLL, John B. (Ed.). Language, Thought, and Reality. Selected Writings of Benjamin Lee Whorf. Cambridge, Massachusetts: The MIT Press, 2011.

CHIESA, Curzio. Le problème du langage intérieur dans la philosophie antique de Platon à Porphyre. In : Histoire Épistémologie Langage, tome 14, fascicule 2, 1992. Théories linguistiques et opérations mentales, pp. 15-30.

FODOR, Jerry A. The Language of Thought. Cambridge, Massachusetts: Harvard University Press, 1975.

LABORIT, Emmanuelle. Le cri de la mouette. (Avec la collaboration de Marie-Thérèse Cuny.) Paris: Robert Laffont, 2003.

LONG, A. A. Stoic Linguistics, Plato'sCratylus, and Augustine's De dialectica. In: FREDE, Dorothea; INWOOD, Brad (Editors). Language and Learning. Philosophy of Language in the Hellenistic Age. Cambridge: CUP, 2008, pp. 36-55.

McGINN, Bernard. The Foundations of Mysticism. New York: Herder \& Herder, 1991. (Vol. I of: The Presence of God: A History of Western Mysticism.)

OGDEN, C. K.; Richards, I. A. The Meaning of Meaning. A Study of the Influence of Language upon Thought and of the Science of Symbolism. (Introd. Umberto Eco.) New York: Harvest/HBJ, 1989.

PANACCIO, Claude. Mental Language from Plato to William of Ockham. (Transl. Joshua P. Hochshild; Meredith K. Ziebart.) New York: Fordham University Press, 2017.

PLATO. Cratylus (Transl. C. D. Reeve); Theaetetus (Transl. M. J. Levett; rev. Myles Burnyeat); Sophist (Transl. Nicholas P. White). In: COOPER, John M. (Editor). Plato. Complete Works. Indianapolis: Hackett, 1984, pp. 101-156; 157-234; 235-293.

PLATON. Kratylos; Theaitetos; Der Sophist. In: EIGLER, Gunther (Herausgeber). Platon. Werke in acht Bänden. Griechisch und Deutsch. Paris: Societé d'Édition « Les Belles Lettres » (Griechische Texte 
1969); Darmstadt: WBG (Deutsche Übersetzungen 1974); 2016, pp. 395-575 (Band 3); pp. 1-218; 219-402 (Band 6).

RAHLFS, Alfred. Septuaginta: Id est Vetus Testamentum Graece iuxta LXX interpretes. Edidit Alfred Rahlfs. Stuttgart: Deutsche Bibelgesellschaft, 2004

RICOEUR, Paul. Sobre a tradução. Belo Horizonte: Editora UFMG, 2011. (O desafio e felicidade da tradução, pp. 21-31; O paradigma da tradução, pp. 33-57.)

SANTANA, Ana Paula. Surdez e linguagem. Aspectos e implicações neurolinguísticas. 4. a ed. São Paulo: Plexus, 2007.

SAUSSURE, Ferdinand de. Curso de linguística geral. São Paulo: Cultrix, 2006.

SEARLE, John R. A redescoberta da mente. São Paulo: Martins Fontes, 2006. Intencionalidade. São Paulo: Martins Fontes, 2002.

STIVER, Dan R. The Philosophy of Religious Language. Malden, MA: Blackwell, 2004.

THORNTON, Tim. Wittgenstein sobre a linguagem e o pensamento. (Trad. Alessandra Siedschlog Fernandes; Rogério Bettoni.) São Paulo: Loyola, 2007.

WITTGENSTEIN, Ludwig. Philosophical Investigations. (Transl. G. E. M. Anscombe; P. M. S. Hacker; J. Schule.) 4th ed. Oxford: Wiley-Blackwell, 2009.

Tractatus logico-philosophicus. Trad. Luiz Henrique Lopes dos Santos. São Paulo: EDUSP, 2010.

Tractatus Logico-Philosophicus. Transl. C. K. Ogden; Introd. Bertrand Russell. Mineola, NY: Dover Publications, Inc. 2017. 